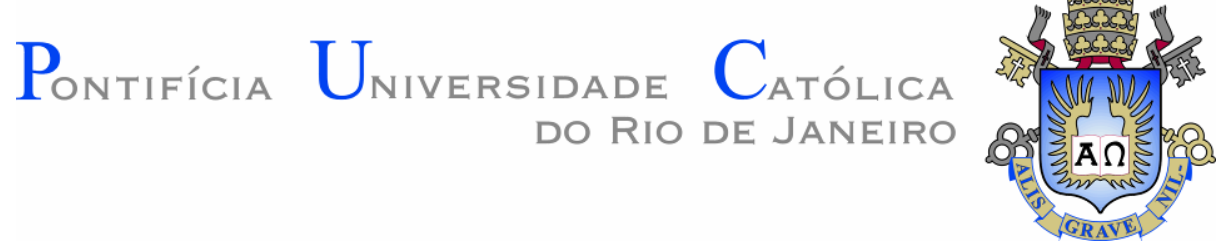

Nelson Antonio Pinho Santos

\title{
Guardiãs da cura: o saber das benzedeiras do Vale do Paraíba do Sul Fluminense
}

\section{Dissertação de mestrado}

Dissertação apresentada ao Programa de Pósgraduação em Literatura, Cultura e Contemporaneidade da PUC-Rio como requisito parcial para obtenção do título de Mestre em Letras.

Orientador: Prof. Alexandre Montaury Baptista Coutinho 


\title{
Nelson Antonio Pinho Santos
}

\author{
Guardiãs da cura: o saber das benzedeiras \\ do Vale do Paraíba do Sul Fluminense
}

Dissertação apresentada como requisito parcial para obtenção do grau de Mestre pelo Programa de PósGraduação em Literatura, Cultura e Contemporaneidade da PUC-Rio. Aprovada pela Comissão Examinadora abaixo:

\author{
Prof. Alexandre Montaury Baptista Coutinho \\ Orientador \\ Departamento de Letras - PUC-Rio
}

Profa. Marília Rothier Cardoso

Departamento de Letras - PUC-Rio

Profa. Aza Njeri

UFRJ

Rio de Janeiro, 26 de abril de 2021 
Todos os direitos reservados. É proibida a reprodução total ou parcial do trabalho sem autorização da universidade, do autor e do orientador

\section{Nelson Antonio Pinho Santos}

Graduou-se em Comunicação Social (Publicidade e Propaganda) na Pontifícia Universidade Católica do Rio de Janeiro, em 2013. Tem experiência na área de Comunicação, atuando principalmente com projetos sobre narrativas orais e memória social.

Ficha Catalográfica

Santos, Nelson Antonio Pinho

Guardiãs da cura : o saber das benzedeiras do Vale do Paraíba do Sul Fluminense / Nelson Antonio Pinho Santos ; orientador: Alexandre Montaury Baptista Coutinho. - 2021.

122 f. ; $30 \mathrm{~cm}$

Dissertação (mestrado)-Pontifícia Universidade Católica do Rio de Janeiro, Departamento de Letras, 2021.

Inclui bibliografia

1. Letras - Teses. 2. Benzimento. 3. Oralidade. 4. Performance. 5. Memória social. 6. Repertório cultural. I. Coutinho, Alexandre Montaury Baptista. II. Pontifícia Universidade Católica do Rio de Janeiro. Departamento de Letras. III. Título.

CDD: 800 
Pela memória de meus mais velhos, meus avós e meu pai, por toda sensibilidade

herdada. A "bença". 


\section{Agradecimentos}

O presente trabalho foi realizado com apoio da Coordenação de Aperfeiçoamento de Pessoal de Nível Superior - Brasil (CAPES) - Código de Financiamento 001.

Agô! Peço licença, agradeço e celebro a todas forças e guias espirituais que me regem e conduzem, inclusive para a realização deste trabalho.

Ao professor, orientador e amigo Alexandre Montaury, pela sensibilidade, compreensão e carinho durante as sábias trocas que me iluminaram e guiaram nessa pesquisa.

Aos professores Eneida Leal Cunha, Frederico Coelho e Marília Rothier Cardoso, com os quais tive a honra de aprender e trocar com seus fundamentais conselhos. Os suportes e aconselhamentos de vocês foram imprescindíveis para a realização deste trabalho.

Ao professor Miguel Iost, por abrir os caminhos e me apresentar ao Programa de Pós-Graduação em Literatura, Cultura e Contemporaneidade da PUC-Rio.

À professora Aza Njeri pelas críticas e aconselhamentos em minha qualificação, fornecendo, com toda sua generosidade, "bons ventos" para os pensamentos.

À CAPES e a PUC-Rio, pelo subsídio material e auxílios concedidos para a realização deste estudo, especialmente no período de pandemia;

Aos professores e servidores do Departamento de Letras da PUC-Rio e a todos colegas do Mestrado, graças a essa comunidade encontrei acolhimento, conversas e debates que guardo e seguem reverberando em mim.

À todas as benzedeiras que participaram da realização desta pesquisa, direta ou indiretamente, principalmente às que sempre me abençoaram e seguem me iluminando: tia Rose, Nara e dona Fátima. Graças a vocês é possível vislumbrar valores que produzem e encantam a vida.

Ao pai Cleber de Oxóssi e a toda comunidade religiosa da Tenda Espírita Caboclo Rompe Mato e Boiadeiro Menino que me amparam, fortalecem e conduzem naquilo que é preciso ser dito. 
À toda comunidade quilombola de São José da Serra, que seguem resistindo e reverberando força, luta e potência de vida, lembrando-me da importância e necessidade desta pesquisa.

Ao povo Puri, pela inspiração e bravura ao resistem e ressurgirem conservando sabedorias e encantamentos. Em especial à professora Marilda Vivas Puri pelas indicações precisas em mostrar os caminhos que me possibilitaram pesquisar e escrever sobre as muitas narrativas de nossa terra.

À minha família, especialmente mãe e irmão, que sempre estiveram ao meu lado, acreditando no meu potencial para pesquisar sobre nossa história e me dão forças para seguir em frente.

Ao meu namorado e companheiro de todas as horas pelo suporte, reflexões, amor e cuidado.

Às minhas amigas e amigos que estiveram presentes, mesmo virtualmente, fortalecendo e criando condições para que pudesse me estruturar e seguir na pesquisa neste atual período tão difícil.

Ao Pedro Bonfim Leal, por me incentivar e amparar em todos os momentos.

À banca examinadora, por aceitarem o convite e compartilharem com alguns de seus pensamentos. 


\section{Resumo}

Santos, Nelson Antonio Pinho. Guardiãs da cura: o saber das benzedeiras do Vale do Paraíba do Sul Fluminense. Rio de Janeiro, 2021. 122p. Dissertação de Mestrado - Departamento de Letras, Pontifícia Universidade Católica do Rio de Janeiro.

A dissertação Guardiãs da cura: o saber das benzedeiras do Vale do Paraíba do Sul Fluminense possui como objetivo central desenvolver argumentos analíticos acerca das práticas e tradições orais de benzedeiras da região do Vale do Paraíba do Sul Fluminense, tendo seu lócus na cidade de Valença, estado do Rio de Janeiro. O trabalho propõe, em um primeiro momento, elaborar uma breve análise da historiografia oficial da região, marcada pela produção cafeeira do período colonial, examinando a hipótese de uma "identidade tradicional valenciana", de um passado "glorioso". A partir da reflexão e problematização deste passado identitário, elabora-se, em um segundo momento, um percurso por narrativas outras, aquelas apoiadas sobre as tradições de cura e articulações de forças no território do Quilombo São José da Serra, localizado na Serra da Beleza, no distrito de Valença. A pesquisa segue a partir dos registros de experiências individuais e de notas produzidas em estudos de campo junto às benzedeiras da região. Como referencial teórico, a dissertação mobiliza trabalhos de diferentes áreas de conhecimento, como, dentre outros, o uso que faz do conceito expandido de performance, cuja análise auxilia a definir um ponto central neste trabalho: a identificação de formas de resistência e (re)existência de práticas simbólicas tradicionais através de tecnologias orais. Em síntese, o presente estudo consiste no reconhecimento desse conjunto de saberes do benzimento da região como uma costura a contrapelo, que evidencia abismos sociais e culturais através dos encantamentos pela palavra e como estratégia de manutenção da vida.

\section{Palavras-chave}

Tradição oral; Oralidade; Performance; Memória social; Ecologia de saberes; Repertório cultural; Religiosidade popular. 


\section{Abstract}

Santos, Nelson Antonio Pinho. Guardians of the cure: the knowledge of the healers of Vale do Paraíba do Sul Fluminense. Rio de Janeiro, 2021. 122p. Dissertação de Mestrado - Departamento de Letras, Pontifícia Universidade Católica do Rio de Janeiro.

The dissertation Guardians of the cure: the knowledge of the healers of Vale do Paraiba do Sul Fluminense has as main objective to reflect on the oral practices and traditions of healers in the region of Vale do Paraíba do Sul Fluminense, having its locus in the city of Valença, RJ. First, a brief history of the region is proposed. Marked by coffee production during the imperial period, the present work raises the analysis of whatwould be a "traditional Valencian identity"; of a "glorious"; past. Then, the focus passes to the narratives about healing traditions and articulations of forces in the Quilombo São José da Serra territory, also located in the region. With the expanded concept of performance as a theoretical tool, the analysis reaches its main point: the wisdoms that resist and re-exist through oral technology. In retrieving individual experiences and notes taken in field studies, results of research in different areas of knowledge are combined. In summary, the present study consists in the recognition of this set of knowledge of the healers of the region as a seam against the current, which shows social and cultural gaps through the enchantments by the word and as a strategy for maintaining life.

\section{Keywords}

Oral tradition; Orality; Performance; Social memory; Ecology of knowledge; Cultural repertoire; Popular religiosity. 


\section{Sumário}

1. Apresentação 10

2. Raízes do Paraíba do Sul Fluminense 18

2.1. O caso valenciano: releitura sobre a glória 18

2.2. Relendo a contrapelo: aquilombamentos em prol da vida 41

3. Corpo que cura $\quad 54$

3.1. Memória, arquivo e oralidade 55

3.2. Encantamentos e benzimentos 65

3.3. O resgate de ancestralidades 86

4. A força da experiência 96

$\begin{array}{ll}\text { 5. Considerações finais } & 108\end{array}$

6. Referências bibliográficas 116 
As rezadeiras usam Águas da chuva e do rio Curam as dores do corpo Cisco no olho, espinhela caída As benzedeiras vão Com fé na oração Curando nossas feridas Como Obaluaê

As rezadeiras quebram Quebranto, mal olhado Males que vem dos ares Nervos torcidos, ventres virados

As benzedeiras são As estrelas das manhãs As nossas anciãs Nanãs buruguêis

Afastam a inveja E o mal olhado Com suas forças Com suas crenças Com suas mentes sãs

As rezadeiras são As nossas guardiãs Por dias, noites.

Martinho da Vila e Rosinha de Valença, Rezadeiras Guardiãs 


\section{Apresentação}

Esta dissertação parte de uma pesquisa sobre as práticas das benzedeiras que atuam e marcam a história da região do Vale do Paraíba do Sul Fluminense. A partir da premissa de que, em suas práticas de cura, as benzedeiras ativam ou recuperam múltiplas perspectivas culturais e matrizes religiosas, optei por elaborar um trabalho de pesquisa de caráter transdisciplinar, que permita descrever e analisar um quadro sociocultural pouco estudado até o momento ${ }^{1}$.

O processo de realização desta dissertação implicou, portanto, a observação e o trabalho de campo integrados a uma pesquisa bibliográfica para dar conta e examinar algumas destas importantes práticas de cura. Afinal, apesar de tantos modos de adoecer, física ou espiritualmente, as benzedeiras do Vale do Paraíba resistem no cultivo da vida, reafirmando e promovendo valores e conhecimentos que auxiliam nos processos das mais variadas formas de cura.

Dentro dos campos de estudo das ciências religiosas, o exercício das benzedeiras é, muitas vezes, associado a uma cultura popular que dialoga com a religiosidade. É comum identificar uma associação direta com experiências religiosas que assumem uma ideia de cultura e religiosidade com base no “catolicismo popular" (Azevedo; Lemos, 2018), pressupondo aglutinações simbólicas cosidas no benzimento.

Tendo nascido em Valença, cidade marcada pela forte presença da Igreja Católica, vivenciei no cotidiano familiar e comunitário muitos dos conflitos que marcam a história do Brasil, as suas heranças coloniais, e o desprestígio de saberes considerados inferiores no horizonte do projeto que uma autodeclarada elite brasileira imaginou como "o bom caminho para o Brasil". As matrizes africanas e indígenas destes saberes tradicionais acumulados na região contrastam radicalmente com a busca por uma suposta diferenciação racial branca, que não se fez sem violências das mais diversas ordens, que passam por genocídios, etnocídios

\footnotetext{
${ }^{1} \mathrm{O}$ projeto de pesquisa desta dissertação teve que ser adaptado ao longo de seu desenvolvimento devido à pandemia do vírus Covid-19.
} 
e epistemicídios (Lemos, 2016). Esta configuração excludente perpassa a elaboração de discursos oficiais políticos, chegando até à organização seletiva dos álbuns de família (quem fica em destaque, quem é deixado em segundo plano ou até suprimido).

O trabalho dessa pesquisa é inspirado pelo reconhecimento de raízes e de ancestralidades que pulsam e marcam a história do lugar onde nasci e cresci. A cidade de Valença, cortada pelo Rio Paraíba do Sul e localizada no interior do estado do Rio de Janeiro, é historicamente reconhecida por compor o Vale do Café. A região foi de grande importância para o período imperial brasileiro. Para além das narrativas que enfatizam as glórias, as riquezas e a prosperidade relativas ao seu desenvolvimento, a história do local é marcada por invasões, disputas por terras, utilização de mão-de-obra pela escravização de pessoas e todas as imposições incentivadas e justificadas pela colonialidade em sua instituição (Silva, 2014).

O retrato de uma sociedade que vive a nostalgia pelo fim do período cafeeiro parece expor um tipo de visão de mundo incapaz de admitir outras formas de vida, outras formas de crer e de praticar a fé. $\mathrm{O}$ esforço de apagamento destas práticas remete para aquilo que caracteriza o conflito racial brasileiro. Sueli Carneiro (2005), jogando luz sobre o conceito de epistemicídio, utilizado por Boaventura de Sousa Santos (2000, 2007), definiu o fenômeno como forma de "rebaixamento da autoestima que o racismo e a discriminação provocam no cotidiano escolar; pela negação aos negros da condição de sujeitos de conhecimento, por meio da desvalorização, negação ou ocultamento das contribuições do Continente Africano e da diáspora africana ao patrimônio cultural da humanidade; pela imposição do embranquecimento cultural e pela produção do fracasso e evasão escolar" (Carneiro, 2005, p. 93).

A tentativa de apagamento das tradições africanas, dos povos originários e dos âmbitos populares é coerente com as práticas de uma tradição colonial hegemônica que supostamente preservaria a essência da história valenciana. Esta identidade deveria, portanto, incluir a marca da "glória" e das benesses concedidas a alguns privilegiados que detinham o poder de uma época considerada de ouro. A narrativa elaborada ao redor do mito fundador da cidade exige, portanto, a exclusão de agentes fundadores, como forma de instituir valores e representações que visam garantir um status quo das parcelas mais beneficiadas da população. Contrariando 
esse princípio ordenador, a região aqui focalizada é marcada pela pluralidade de manifestações culturais e religiosas, que permitem visualizar distintos valores, tradições e histórias herdadas. Mesmo com alguns avanços e garantias, é preciso estar atento aos enunciados que seguem desvalorizando principalmente as contribuições dos povos originários, dos povos africanos e de seus descendentes em diáspora.

Recentemente, um longo passado de violências reais e simbólicas ganhou novo fôlego com o fortalecimento da influência de religiões de discurso intolerante nesta região, assim como no restante do Brasil. Numa sociedade que segue produzindo diferenciações e hierarquizações, as tentativas de apagamento, simbólicas ou não, de vivências e vidas, permanece em ação. Ao lançar um olhar para os contornos históricos da cidade de Valença, visualizo fenômenos e potências que seguem resistindo. Passamos a identificar tradições pulsantes nas terras e nas memórias, individuais e coletivas, nas narrativas e práticas em prol da vida. Estas seguem conduzindo e vitalizando os moradores e a cultura local, possivelmente de forma semelhante ao que ocorre em muitas regiões Brasil afora.

Como motivação pessoal, um dos principais motores na busca pelo tema de pesquisa foi evocar memórias - nítidas ou vagas - que me constituem. O percurso pelo mestrado no Programa de Pós-Graduação em Literatura, Cultura e Contemporaneidade me muniu não apenas de um referencial teórico. Foi um momento de entrar em contato com novas ideias e discussões, ressignificar personagens e vivências pessoais, entender aproximações e afastamentos na minha história individual. Ir atrás das linhas de força que atravessam a minha existência, as tensões e impulsionamentos que ressignificam e marcam a minha identidade, da cidade em que nasci, e do próprio Brasil foi, portanto, o interesse de fundo em meu trabalho.

As experiências em CTTro ${ }^{2}$ e com agentes da fé, iniciadas muito antes desse trabalho, ganharam contorno e importância fundamentais para a realização desta

\footnotetext{
2 A exemplo do professor e babalorixá Sidnei Nogueira, "Adotar-se-á o termo CTTro - Comunidade Tradicional de Terreiro - como uma denominação aglutinadora de todas as práticas afro-brasileiras também chamadas Religiões de Matriz Africana ou tradições afro-brasileiras, como Umbanda, Candomblé, Xambá, Nago-egbá, Batuque, Tambor de Mina, Jurema e aparentados. Diante da perseguição, somos todos "macumbeiros" - no sentido negativo da palavra -, por isso é preciso que nos vejamos todos como irmãos e parte de uma cultura com gênese comum" (Nogueira, 2020, p.138)
} 
dissertação. Ao longo do processo de pesquisa, passei a reconhecer nos relatos colhidos - de minha família, de minha comunidade - incoerências já identificadas, mas até então assimiladas por mim. Ao falar sobre o investimento inicial de minha pesquisa sobre a fé que circunda pela região valenciana, o primeiro conselho de dona Maria Padilha, entidade pombajira do pai Cléber de Oxóssi da Tenda Espírita Caboclo Rompe Mato e Boiadeiro Menino foi justamente: "estude sua família". Daí surgiu um primeiro incômodo e a quase recusa em empreender uma pesquisa particular sobre buscar algo que evidenciasse o que nem eu mesmo ainda tinha nítida percepção. Ao ir até os meus mais velhos, pude começar a elaborar argumentos sobre as influências que sempre senti. Quando criança, ouvia vozes, presenças, sentia medo de quase tudo e só encontrava afago nas rezas dos meus.

A existência de parentes benzedores, pessoas que tinham seus assentamentos, cuidados próprios com suas forças espirituais, era em geral abafada. De geração em geração, como uma história espiralada, um legado se forma fora dos relatos oficiais. "Deram como loucos ou fora de seus juízos". É conhecida a existência de relatos, acionados por linhas de força pautadas no silenciamento/ocultamento, da conexão também de outros parentes que atuam na indústria religiosa de orientação intolerante com a diversidade.

Reconhecer crítica e analiticamente tais atritos e seus desdobramentos me pareceu então, para esta pesquisa, mais do que uma investigação familiar pessoal. Tratou-se, sim, da elaboração de um caso singular, mas que espelha urgências mais amplas de nossa época. Falar não de mim, mas a partir de mim. Procuro jogar, assim, luz em características dessas histórias que revelam nuances para uma leitura crítica das práticas culturais, políticas e religiosas, inseridas no universo do benzimento na região da cidade de Valença.

A história valenciana é traçada por muitas mãos, múltiplas ancestralidades. Vale destacar que por ancestralidade devemos tomar olhares cautelosos. A ancestralidade presume uma ética, praticada no cotidiano, no voltar-se para as forças que constituem o ser individual e comunitário (Simas, Rufino, 2018). Afinal, "ser" é estar em comunidade, reafirmar os laços que conduzem a entendimentos da vida e a formas de estar no mundo. 
Assim, ao ler a tradição do benzimento, uma amálgama de rezas e de práticas ancestrais, é preciso entender através de que lentes.

O professor doutor Munanga (2014), em Uma abordagem conceitual das noções de raça, racismo, identidade e etnia, destaca a luta ainda constante pelo respeito e pelo reconhecimento do direito de cada um a cultivar a sua diversidade, o que em linhas gerais contribui para a pluralidade cultural:

Têm-se culturas particulares que escapam da cultura globalizada e se posicionam até como resistência ao processo de globalização. Essas culturas particulares se constroem diversamente tanto no conjunto da população negra como no da população branca e oriental. É a partir da tomada de consciência dessas culturas de resistência que se constroem as identidades culturais enquanto processos e jamais produtos acabados. São essas identidades plurais que evocam as calorosas discussões sobre a identidade nacional e a introdução do multiculturalismo numa educaçãocidadã, etc. Olhando a distribuição geográfica do Brasil e sua realidade etnográfica, percebe-se que não existe uma única cultura branca e uma única cultura negra e que regionalmente podemos distinguir diversas culturas no Brasil (Munanga, 2014, p. 11).

A partir do argumento do professor Munanga, é possível visualizar a cultura do benzimento, sobre a qual esta dissertação se debruça, como um campo de resistência cultural. Comumente associada ao catolicismo popular, o benzimento deve ser reconhecido como herança ancestral que afirma a pluralidade de suas práticas. Em oposição a estruturas religiosas oficiais, em conexões comunicantes, assimilando vozes hegemônicas e assumindo formas híbridas, o benzimento coexiste numa plural ecologia de saberes (Santos, 2007).

Assim, esta pesquisa investiga as linhas de força atuantes nas narrativas de benzimento, praticadas por muitas guardiãs na região Sul-Fluminense. Elas, as guardiãs do conhecimento das ervas, preservam o vínculo profundo em comunidade, reunindo diversas temporalidades e dinâmicas. O território religioso de Valença e seus entornos é um espaço de tensão coerente com a organização política e cotidiana de seus habitantes (Lucinda, 2016).

O gesto de observação e reflexão sobre a existência das benzedeiras ilumina a experiência gerada por essas agentes da fé que carregam sabedorias tradicionais em suas falas e na energia dos raminhos do mato. Suas práticas e redes de sociabilidade são construídas em espaços historicamente marcados pela estratégia 
de resistência, e é neste sentido que o estudo segue costurando narrativas que (re)existem na construção e na elaboração da cura pela vida física e simbólica.

Em sua oralidade, cada benzimento carrega significados diversos e se relaciona de forma particular na vida de cada pessoa. Este estudo, então, objetiva analisar e reconhecer a importância da memória e da oralidade neste contexto. A cada reza praticada, a tradição é reafirmada, fortalecendo o nível de entendimento da experiência de cura nas pessoas benzidas. Uma mesma oração é uma articulação des energias dentro de uma causa/efeito que também pode ser repetida inúmeras vezes, de maneiras diferentes, para que cada ouvinte possa perceber de que modo aquela cura e absorção de energia vital da palavra se ativa.

Assim como as histórias que são transmitidas oralmente, as memórias são cultivadas e aprendidas enquanto performances incorporadas por seus repertórios de conhecimentos (Taylor, 2013). Cada erva ou planta utilizada no processo de cura deve ser guardada e transmitida para a posteridade. Cada ritual e ensinamento precisa ser mantido a partir de sua prática e conhecimento. Há um certo grau de inventividade a partir das conexões intuídas, mas todos os fundamentos que as direcionam devem ser respeitadas e repassadas no ato da cura. As feridas e quebrantos precisam ser recordados para que se possa levar a cura para dores físicas, psíquicas e simbólicas - ensinamentos passados de gerações em gerações.

O estudo sobre as práticas do benzimento pretende localizar suas epistemes, valorizando o cultivo do cuidado em comunidade. $\mathrm{O}$ ato de tomar uma reza e pedir a benção, principalmente aos mais velhos, são costumes que também revelam africanidades e valores ancestrais de tradições nativas que se comungam. Assim, a pesquisa visa compreender uma reflexão acerca da importância do tempo para a manifestação desses saberes. A argumentação prevê um senso de pertencimento, de conexão com o meio natural e assume um compromisso de respeito radical à natureza, partindo da ideia de que tal percepção não vem com a posse, sentido de propriedade que funda a sociedade moderna. A cura se baseia em um processo coletivo de ativação da saúde individual e coletiva. A cura de si, compartilhada em comunidade, ativa sabedorias que sustentam a revitalização energética pela melhora dos males que afetam suas vidas. A partir dessas definições, este campo de resistência cultural afirma o cuidado como um vetor fundamental de potência de vida. 
Como metodologia, o presente trabalho considerou a historiografia local, lida em perspectiva crítica e analítica, remetendo ao período de fundação de Valença. No primeiro capítulo, estudos de historiadores e pesquisadores evidenciam os processos sociais que moldaram um senso comum acerca da região, que inclui o projeto moderno para a sociedade valenciana. Ainda neste capítulo, recupero narrativas que se opõem a este modelo de sociedade e que afirmam uma organização afro referenciada de resistência como os quilombos (Nascimento, Beatriz in: Ratts, 2006) (Nascimento, Abdias, 1980), em perspectiva com as experiências e os relatos dos moradores do quilombo São José da Serra, o mais antigo do estado do Rio de Janeiro.

A partir de documentários, vídeos e publicações a respeito do quilombo São José da Serra foi possível apresentar um panorama que pudéssemos visualizar as manifestações e organizações estratégicas que permitem afirmação e continuidade em seu território, no campo político, cultural e religioso.

No segundo capítulo, as discussões sobre oralidade, memória e práticas de cura mantidas no benzimento são privilegiadas. As discussões sobre a manutenção de tradições a partir das tecnologias orais serão abordadas principalmente a partir das reflexões teóricas sobre performances culturais e sobre a noção de arquivo.

Como metodologia de análise, orientamos a pesquisa ao estudo de campo através de observação participante e de diálogos registrados em diários com benzedeiras de minha familiaridade. As conversas com as benzedeiras dona Fátima, Nara e tia Rose foram transcritas ao longo deste trabalho. Para compor a articulação de memórias de benzedeiras da região do Vale do Paraíba Sul Fluminense, serão destacadas também as transcrições de falas de outras benzedeiras da região a partir de vídeos disponíveis em acesso digital, adaptado às limitações decorrentes das limitações que marcaram o período de realização da pesquisa.

No terceiro e último capítulo, a noção de experiência é abordada em perspectiva com uma cultura hegemônica que parece validar apenas o pensamento racional e científico, eurocentrado, exigindo que se revisitem experiências tradicionais de ativação de cura. Ainda neste capítulo serão abordados aspectos relativos à presença de benzedeiras em cursos profissionalizantes e atuações em redes sociais, expandindo a reflexão sobre tais experiências na contemporaneidade. 
Em síntese, a dissertação almeja produzir uma reflexão crítica sobre as tradições do/no benzimento tal como elas se mantêm na região do Vale do Paraíba Sul-Fluminense. Não seria possível imaginar que esta pesquisa exaurisse os temas nela implicados, organizando em categorias fixas os objetos analisados. Parte-se da ideia de que culturas de resistência são abertas, estão em constante articulação de forças para se manterem vivas, assim como as suas práticas. O que se pretende, finalmente, é trabalhar na direção da afirmação múltipla da vida, reconhecendo distintas potencialidades em suas diversas formas de atuação pela cura e fortalecimento dos seres. 


\section{2 \\ Raízes do Paraíba do Sul Fluminense}

\section{1. \\ O caso valenciano: releitura sobre a glória}

O município de Valença se localiza no sul do estado do Rio de Janeiro e está situado entre os vales do Médio Paraíba fluminense, às margens do rio Paraíba do Sul, o rio Bonito ${ }^{3}$. Atravessado igualmente pelo rio Preto, essa região era habitada por povos originários conhecidos como Coroados, denominação genérica dada pelos colonizadores portugueses a todas as tribos que usavam cocares em forma de coroa $^{4}$. Tem-se conhecimento de que ao longo do Rio Paraíba viviam as sociedades Puri ou Purus, Coroados, Arari ou Ararizes e Caxaxenes ou Caxixunes (Lemos, 2016, p. 45). Há uma indicação mais precisa de que os povos originários que habitavam a região da cidade de Valença eram pertencentes ao tronco Macro-Jê, "linguisticamente vinculados à família Puri-Coroado" (ibid., p. 58), etnia considerada extinta por falantes da língua, mas que resistiu e vem sendo resgatada por movimentos ressurgentes de seu povo.

Dados do censo realizado em 2010 revelam que a cidade de Valença possui uma população de aproximadamente 71.843 habitantes, distribuídos em uma área territorial de $1.304,813 \mathrm{~km}^{2}$ e com uma densidade demográfica de 55,06 habitantes por $\mathrm{km}^{2}$, segundo o IBGE. A cidade se localiza a $160 \mathrm{~km}$ do Rio de Janeiro e tem proximidade com muitas regiões mineiras, estando a $105 \mathrm{~km}$ de Juiz de Fora ${ }^{5}$.

Segundo informações do IBGE (2017), a história grafada sobre o município "inicia-se por volta de 1789, quando D. Maria I de Portugal, através de uma Carta Régia, incumbiu ao vice-rei Luiz de Vasconcelos e Souza que promovesse o início

\footnotetext{
${ }^{3}$ PENSARIO. Identidades do Rio, s.d. Disponível em: $<$ http://www.pensario.uff.br/node/235 $>$. Acesso em: 15 ago. 2020.

${ }^{4}$ Como Lemos aponta, "esta denominação não ajuda muito a esclarecer o modo de vida dessas sociedades indígenas; ao contrário, às vezes confunde sociedades indígenas diferentes com o mesmo apelido" (Lemos, 2016, p. 50).

${ }^{5}$ Dados retirados da dissertação de Silva (2014), mas que fazem referência ao IBGE e de livros como Uma pequena História de Valença, de Rogério Tjader, e também de Valença de Ontem e de Hoje - 1789 - 1952 - Subsídios para a História do Município de Marquês de Valença, do autor Leoni Iório.
} 
da catequese dos índios denominados Coroados, que por aqui já constituíam um núcleo incipiente de povoamento". ${ }^{6} \mathrm{O}$ aldeamento de fazendeiros situado em Valença passou então a ser uma atividade incentivada pela monarquia portuguesa e promovida por iniciativas privadas. Frente a isto, a imagem construída ao longo do tempo é a de que os povos que habitavam a região teriam sido dizimados pelas frentes de expansão que tomavam suas terras.

A região da cidade de Valença foi inicialmente reconhecida como vila rural e, até o início do século XIX, era "quase toda uma grande floresta virgem, sendo sua principal importância o fato de ser passagem quase obrigatória das rotas, especialmente comerciais, que ligavam o sul da Província Minas Gerais à cidade do Rio de Janeiro" (Pinheiro, 2015). Isto é comprovado por seus habitantes, que reconhecem numa das principais ruas, ligada à Catedral de Nossa Senhora da Glória, a rua dos Mineiros.

Ao investigar sobre o que seria uma Identidade Valenciana, construída no aporte da memória de seus cidadãos e na imprensa local, Silva (2014), em sua dissertação, fornece dados a partir de uma leitura crítica da bibliografia oficial sobre Valença, o que possibilita para o presente trabalho suporte teórico sobre a historiografia local. A pesquisadora, ao descrever a passagem dos tropeiros que vinham de Minas Gerais com destino ao Rio de Janeiro, cita Leoni Iório, historiador autor de Valença de ontem e de hoje: Subsídios para a história do município de Marquês de Valença, 1789-1952, onde afirma que "os tropeiros mineiros, na sua árdua missão, entravam, assim, triunfalmente, na velha cidade de Valença, cuja população, transbordante de alegria imensa, os recebia com festas e aplausos" (Iório apud Silva, 2014, p. 24). Segundo a versão oficial, uma narrativa de glória é transmitida sobre essas ocasiões. Assim, o principal logradouro da cidade teria sido uma homenagem a estes viajantes.

Silva, ainda em seu estudo, vai além desta espécie de discurso mítico sobre a origem da cidade, investigando e levantando um inventário de obras literárias de diferentes gêneros que a levam a uma "ideia-força" que fundamenta o processo de formação da identidade local.

\footnotetext{
${ }^{6}$ IBGE, 2017. Disponível em: < https://cidades.ibge.gov.br/brasil/rj/valenca/historico>. Acesso em: 24 ago. 2020.
} 
É neste levantamento que a autora localiza uma "identidade tradicional valenciana" emergindo nas narrativas das principais obras literárias "cujos temas giram em torno da história de Valença" (ibid. p. 25). Assim, Silva nos fornece instrumentos que auxiliam a expor alguns dos tensionamentos com outras narrativas que habitavam e passaram a habitar esta região sul fluminense. É perceptível, a partir da análise da autora, o destaque de publicações em menção ao período cafeeiro de Valença, o que não ocorre com a posterior fase industrial da cidade. Até então, mesmo com a notoriedade da indústria têxtil na época, não há nenhuma publicação cujo tema seja exclusivamente este momento posterior.

Já o período cafeeiro aparece caracterizado na literatura como momento de "grande glória" para a região - glória destinada somente para alguns. Os estudos nas áreas de Ciências Humanas e Sociais destacam a maciça presença de pessoas que foram escravizadas vindos do continente africano para a região e a atuação senhorial desses "proprietários de terras", reforçando "indiretamente, mas de forma efetiva, a invisibilidade da população indígena que ali já se encontrava numerosa" (Lemos, 2016, p. 13).

Esta época "mítica", celebrada como marco da identidade valenciana, talvez não por acaso configure também um período extremamente conflituoso na região. A monocultura de café exigiu a invasão de longas extensões de terra, o que levou à expulsão dos nativos da região após muitos conflitos. Foi durante o período cafeeiro, igualmente, que se utilizou uma larga quantidade de mão de obra de escravizados. Antes de tudo, é digno de nota que o período mais celebrado para a narrativa do discurso oficial seja também aquele que abarque em si violências de tantas ordens contra populações não hegemônicas.

Em seu livro $O$ índio virou pó de café? Resistência indígena frente à expansão cafeeira no Vale do Paraíba, Lemos investiga relatos que confrontam a historiografia oficial, em que, "ao contrário de registros formais e de um difuso senso comum, as populações originárias existiram e deixaram suas marcas na sociedade que se tornava nacional" (ibid, p.13). Segundo Lemos, os descendentes diretos dessa população podem ainda hoje ser localizados na região, comprovando a dimensão política do desaparecimento, ao menos nos relatos oficiais, dos povos originários daquelas terras. 
O período que marca economicamente a história da região, segundo estudiosos como Lemos e Braz, Sena e Silva (2020), é ligado ao ciclo do café, que transformou a economia nacional e a paisagem, "rasgando a floresta, conquistando o Vale do Paraíba num ritmo acelerado, fundando vilas e povoados, que implicarão um impacto acentuado aos povos indígenas fluminenses" (Lemos, 2016, p.19). Sobre as particularidades no processo de apropriação das terras situadas em Valença, Lemos destaca:

Nesta área, a questão aparecerá como decorrente do processo de expansão da fronteira agrícola, que num primeiro momento era impulsionada pelo crescimento do setor ligado ao mercado interno (que incorpora esporadicamente o trabalho indígena), dentro do modo de produção escravista colonial, e, posteriormente, pelo setor agro-exportador cafeeiro (estruturado no trabalho escravo), que será a "pá de cal" no espaço indígena dos Coroados. Levando-os para a situação de aldeamento, posteriormente, a destribalização, desterritorialização e "desaparecimento" etnopolítico (ibid., p. 21).

As violências e desumanizações do projeto colonial visavam a promoção da dominação física e simbólica, numa estrutura de poder de extermínio de saberes, que acometeram às populações originárias locais e aos povos africanos que passaram a habitar as terras do Vale do Paraíba. Pouco a pouco as invasões dos territórios originários foram expropriando seus habitantes e negando o reconhecimento de suas culturas, tradições, costumes e valores.

A partir das reflexões do historiador, constatamos que os conflitos promovidos pelas ações dos fazendeiros envolveram a fuga do recrutamento forçado e a luta "contra a usurpação da sesmaria da Aldeia, aliando-se a quilombolas, etc." (ibid, p. 23). Este fato é de suma importância para refletir sobre o movimento de resistência da população nativa, em contato com os povos descendentes de diversas regiões de África.

Frente à política voltada à população originária do início do século XIX, o que se estabeleceu na região de Valença "foi a usurpação da terra do aldeamento, que foi apropriado pela Municipalidade, em 1836, pois não reconheciam mais a presença de índios na sede do município" (ibid. p. 25). Lemos defende que o desaparecimento físico na verdade representa o apagamento político (acerca das reivindicações políticas dos Coroados) e, ao mesmo tempo, étnico (os que vivem na sede do município não são mais pertencentes de suas etnias, mas sim caboclos). 
Da mesma forma, os "nobres" valencianos não os reconheciam, desprezando traços físicos e costumes que remetessem suas origens étnicas.

A fundação da cidade de Valença teve o seu marco a partir do reconhecimento de iniciativas de famílias de posse econômica e alianças entre si. Além disso, havia uma expectativa em invadir e apossar as terras para uma sistematização de produtos a serem cultivados nas terras da região:

Existiam laços comuns de amostra da união de clãs familiares, um deles era a dita caridade que ambos praticavam e um exemplo dela era o acondicionamento e a manutenção das Santas Casas de Misericórdia, que atendiam aos mais pobres e desvalidos e que também não deixavam de ser uma forma pela qual as famílias usavam seus sobrenomes para se inserirem na vida política daquele lugar (Braz; Sena; Silva, 2020, p. 23).

Para além dessas famílias que ocuparam e ainda ocupam lugares de destaque enquanto fundadores da cidade, destaco a participação do Padre Aguiar, que, "em 1836, na Vila de Vassouras, publicou um manual contendo um estudo sistemático da estrutura de um cafezal" (ibid. p. 26). A partir dessas publicações e outras encomendadas por estas famílias de fazendeiros, criou-se um estatuto, oferecido à "Sociedade Promotora da Civilização e Indústria da Vila de Vassouras", de práticas administrativas, econômicas e políticas que dariam contorno e mudariam a paisagem e a vida dos habitantes da região. A vila de Valença e a vila de Vassouras tinham uma articulação política convergente, que, aliada à imprensa, passou a ser uma das ações de construção da historiografia oficial da região.

Em 1832, fazendeiros valencianos criaram a "Sociedade Defensora da Liberdade e Independência Nacional da Vila e Valença, que reunira os grandes proprietários de toda a região" (ibid. p. 30). Tal sociedade foi presidida pelo Visconde de Baependy e criou seu próprio periódico, O Valenciano, publicado durante dois anos. Além de artigos políticos, o periódico trazia estudos que defendiam economicamente o cultivo de café na região.

A redação do periódico estava ainda intrinsecamente ligada ao pensamento religioso, sendo inicialmente elaborada por padres. Desta forma, os artigos funcionavam como uma doutrinação em múltiplos aspectos, inclusive no ramo de 
negócios - simpatizando com técnicas dos plantations $^{7}$ dos Estados Unidos e, consequentemente, defendendo uma aproximação com essa técnica.

Sobre o periódico, afirmam:

Da sexta até a vigésima edição, o padre João Joaquim Ferreira de Aguiar, substituto do padre Meireles na redação do jornal, descreveu minuciosamente as técnicas de plantio, o estudo do solo, as estratégias econômicas e até o quanto aquele produto beneficiou a economia dos Estados Unidos (ibid, p. 31).

No entanto, apesar de mirarem um exemplo estrangeiro, Lemos ressalta que a economia colonial da região se mostrava mais complexa do que a plantation americana escravista, "subordinada ao contexto das conjunturas internacionais, dado que em pleno período recessivo da conjuntura internacional ocorre boa parte da montagem da cultura cafeeira do Vale do Paraíba e também o contínuo aumento da produção açucareira campista" (Lemos, 2016, p. 40).

Por outro lado, para fazer valer seus argumentos, o padre Aguiar servia-se de textos clássicos como $O$ Espírito das Leis, de Montesquieu, em que ressaltava a propriedade privada como componente do progresso das nações desenvolvidas, diferenciando de outras nações:

No espírito das Leis aparecem distintos os Povos caçadores, como os selvagens da América; os pastores como os Tártaros e os Árabes; e os povos agrícolas. Os primeiros não podem jamais viver na abundância. Sua população é precisamente restringida ao mais pequeno número em relação à vasta extensão de terreno, que é mister recorrer para subsistência. Os povos que não são agrícolas não podem jamais formar grandes nações ${ }^{8}$.

Ora, ao comentar que povos como "caçadores" e/ou "pastores" não poderiam formar uma grande nação, o padre Aguiar parecia revelar outros temores. Segundo a sua defesa do plantio de café ao estilo norte-americano, somente esta forma de plantio deveria ser empregada, o que não poderia ocorrer sem uma dominação e vetos das demais práticas, numa tentativa de apagar outras técnicas e vivências.

\footnotetext{
7 "O plantation foi um sistema de exploração colonial utilizado entre os séculos XV e XIX principalmente nas colônias europeias da América, tanto a portuguesa quanto em alguns locais das colônias espanholas e também nas colônias inglesas britânicas. Ele consiste em quatro características principais: grandes latifúndios, monocultura, trabalho escravo e exportação para a metrópole." PINTO, Tales dos Santos. "Plantation, um sistema de exploração colonial"; Brasil Escola. Disponível em: $<$ https://brasilescola.uol.com.br/historiab/plantation.htm>. Acesso em 02 nov. 2020. ${ }^{8}$ O Valenciano, Ano I, N.13, - 15 set. 1832 apud Braz;, Sena;, Silva, 2020. p. 39.
} 
Estas orientações, apesar de aparentemente pontuais no chamado à eliminação de modos de vida locais, faziam parte de um programa mais amplo. Tratava-se de, através de uma justificativa iluminista e eurocêntrica, fundamentar o que seria "o destino do Brasil". É desta forma que padre Aguiar afirma ainda:

Quando as Nações não cultivam as terras, diz Montesquieu, eis a proporção da população: o que é o produto de um terreno inculto para o produto de um terreno cultivado. É o número dos selvagens num país para o número dos lavradores noutro país. E quando o Povo agricultor cultiva também as Artes, o número dos selvagens é para o número deste Povo em razão composta do número dos selvagens ao dos lavradores e do número deste ao dos cultivadores das Artes.

Só os Povos agrícolas é que podem viver abastados de tudo principalmente se a cultura da terra eles juntam ao cuidado e criação de gados, cujos lucros diários se acumulam ao produto anual das colheitas?.

A crítica elaborada por diversos autores à violência implícita em discursos como este nos permite ver em falas aparentemente pontuais, de contexto restrito e prescritivas - uma incitação ao apagamento de culturas não eurocentradas, a elaboração de um espaço comum que se faz sob esta diretriz.

Sobre o tema da instituição do comum, destaco aqui o pensamento de Dardot e Laval. Para estes autores, o comum é uma organização que se efetiva na esfera coletiva, e que define e direciona práticas cotidianas.

Para os autores, 'comum' é algo diferente de um terreno de coexistência pacífica ou um simples ocupar o mesmo espaço. A própria constituição de um comum depende de uma interação de interesses, inclusões e exclusões muitas vezes camuflados em um verniz pacifista ou ordenador. Segundo apontam:

A dimensão conflituosa deve ser reconhecida como integrante do comum e não considerada um lamentável "efeito colateral" que se deveria evitar: o comum não se refere a uma "governança" pacífica que funciona de base ao consenso; ele não se constitui, não se perpetua e não se expande de outro modo senão no conflito e por meio dele. O que é instituído como comum está em oposição ativa a um processo de privatização (seja do espaço urbano, da água ou das sementes). (Dardot; Laval, 2015, p. 271).

Seguindo uma inspiração nietszchiana e foucaultiana, Dardot e Laval consideram que a vida em comunidade possui como elemento inevitável a

${ }^{9}$ O Valenciano, Ano I, N.13, - 15 set. 1832. apud ibid., p. 40. 
conjugação de forças conflitantes. Reconhecer este dado inescapável não significa uma exaltação do conflito, mas apenas reconhecer sua permanente existência e reivindicações.

A reflexão dos autores, a partir desta constatação, discorre sobre uma organização excludente do comum feita a partir de uma defesa privilegiada em prol de quem detém o poder de uma época. No artigo Propriedade, apropriação social e instituição do comum (2015), ao citar a frase de Proudhon "a propriedade é um roubo", Dardot e Laval relacionam este trecho à "tradição jurídica que havia levado a fazer da propriedade privada o fundamento da sociedade civil e, correlativamente, da propriedade pública, o domínio particular do Estado" (ibid., p. 261).

Uma vez concedida uma centralidade à propriedade privada, o espaço e instituições públicas do Estado passam a operar para legitimá-la, tornando-se instrumentos para a apropriação de recursos naturais, dos "bens comuns" e dos serviços públicos. Sobre a atuação do comum convertido a um maquinário que garante acesso aos "proprietários" em detrimento a quem não tinha o direito à posse, os autores afirmam:

Não foi preciso apenas mobilizar, unir, concentrar forças repressivas e modos de persuasão ideológica para defender a propriedade contra os não proprietários. Foi preciso também encarregar-se da vida das populações excluídas dos meios de acesso ao trabalho e, portanto, à vida (ibid., p. 266).

Trazendo esta reflexão para o caso de Valença, entender as entrelinhas do que estava em jogo nos discursos que marcam a fundação da cidade é fundamental para que seja possível vislumbrar os valores que se pretendia assentar e perpetuar como verdade absoluta por aqueles que detinham, além do controle das narrativas oficiais, os poderes institucionais, econômicos, políticos e bélicos a seu favor. Entendendo espaço do comum como continuamente sendo forjado, esse estudo busca lançar força a outras narrativas que perfuram o manto de uma definição absoluta e interessada. Isto porque o comum, é importante frisar, não deve se constituir unicamente em torno de garantir bens e interesses particulares.

Frente à discussão do que se dá no espaço comum valenciano, localizamos no momento de fundação da cidade diferentes tensionamentos atuando no sentido de estabelecer uma narrativa oficial que trata esse comum no sentido excludente apontado por Dardot e Laval. Sendo assim, a partir da reflexão destes autores, 
entendemos que esse território de disputas ganha forças a partir do que é produzido, reafirmado e perpetuado em seu cotidiano.

Ainda que de maneira velada, teses como a do padre Aguiar defendem, sob a justificativa da ordem e do progresso, aquilo que deveria ser abraçado daquilo que lançaria a sociedade brasileira na barbárie e no caos, ou não forneceria coesão suficiente para formar uma grande nação. Apesar de aparentemente elaborar uma argumentação isenta e racional para um melhor uso da terra e o bem-social, um texto como o do padre Aguiar nos permite ver - para nós que olhamos pelas entrelinhas - a colocação em marcha de uma sociedade excludente. É sobre estes princípios excludentes que se colocam como condição para se erigir um espaço comum.

É preciso, no entanto, refletir sobre a dimensão eurocêntrica desta tese que só admite um modelo de civilidade, sendo incapaz de admitir a coexistência da diversidade. Para contribuir com esta reflexão, recorro a uma ferramenta conceitual que o sociólogo português, Boaventura de Sousa Santos (2009), chama de pensamento abissal, segundo o autor uma marca do pensamento moderno eurocêntrico.

Segundo este autor, pensamento abissal designaria um padrão de pensamento que enxerga a realidade a partir de um sistema de distinção por linhas radicais, dividindo o mundo em dois polos de realidade: o desenvolvido e o subdesenvolvido, a metrópole e a colônia, o colonizador e o colonizado, o moderno e o primitivo, etc. Tais linhas produzem demarcações já não mais geográficas (Santos, 2009, p. 25). Trata-se, portanto, de uma obsessiva classificação do real em categorias dicotômicas.

\begin{abstract}
A profunda dualidade do pensamento abissal e a incomensurabilidade entre os termos da dualidade foram implementadas por meio das poderosas bases institucionais - universidades, centros de pesquisa, escolas de direito e profissões jurídicas - e das sofisticadas linguagens técnicas da ciência e da jurisprudência. $\mathrm{O}$ outro lado da linha abissal é um universo que se estende para além da legalidade e da ilegalidade e para além da verdade e da falsidade. Juntas, essas formas de negação radical produzem uma ausência radical: a ausência de humanidade, a subumanidade moderna (ibid., p. 30).
\end{abstract}

Tal polarização, no fim das contas, traça uma linha divisória entre "nós" e os outros, estes últimos homogeneizados como bárbaros, primitivos e incivilizados. 
Evidencia-se, com o conceito de pensamento abissal, todo um sistema excludente de dominações políticas, econômicas e culturais, pois estas linhas demarcatórias são altamente excludentes. No entanto, elas se encontram já engendradas em nossa sociedade, definem e constroem diferenciações a todo momento do que é aceitável e do que é descartável.

Voltando ao exemplo do texto do padre Aguiar, o pensamento abissal se encontra ali presente pela suposição de uma sociedade dividida entre selvagens e civilizados. Já seria muito se, ainda que abafando uma multiplicidade de categorias não captadas por suas dicotomias, o pensamento abissal respeitasse os valores e a humanidade de quem atribui como "o outro". Ocorre que essa divisão dicotômica carrega também em si classificações entre o bem e o mal, o primeiro devendo prevalecer sobre o segundo, este último tratado como inimigo a ser combatido. Desse modo, a civilidade deveria vencer a selvageria, assim como a luz busca dissipar a escuridão.

Ao defender uma via de mão única para a civilização, portanto, aquilo que não cabe ou não se adequa aos trilhos do progresso deveria ser eliminado. Isto abarca, evidentemente, os modos de produção e cultivo da terra, mas, principalmente, recai sobre as formas de vida nativas, com seus saberes específicos, que, ao serem identificadas com o atraso, são colocados na mira da destruição.

O artigo de Souza e Boakari (2018), ao jogar luz também sobre o conceito de epistemicídio que ocorre nesta estrutura de pensamento, evoca o texto de Grosfogel:

Mas seria então possível a consolidação hegemônica do eixo Norte global a partir da filosofia cartesiana? Grosfoguel (2016) explica que o "penso, logo, existo" é precedido de duas premissas "conquisto, logo, existo" e "extermino, logo, existo". Não devemos esquecer duas outras premissas "sou superior, porque sou de aparência pura, branca" e "tenho o direito de querer o que é dos outros". A instauração desse pretenso direito universal e as consequentes desqualificações e inferiorizações epistemológicas e humanas do Sul-global são decorrentes da modernidade/colonialismo, que instaurou a dominação e conquista de outros territórios (África, Américas e Ásia), bem como, o extermínio de tudo e todos que desafiavam este movimento. Ao dominar o mundo, os europeus estariam assumindo uma posição equivalente a Deus e, por isso, autorizados a destruir, desqualificar o/a outro/a: "É a lógica conjunta do genocídio/epistemicídio que serve de mediação entre o 'conquisto' e o racismo/sexismo epistêmico do 'penso' como novo fundamento do conhecimento do mundo moderno e colonial" (Grosfoguel apud Souza; Boakari, 2018, p.31). 
Não é à toa que uma das marcas do pensamento moderno seja o movimento iluminista europeu, cujo marco inicial é justamente a máxima de Descartes, "penso, logo existo" - iluminismo de iluminação, a luz que deve vencer as trevas. Em sua grande parte, o movimento de colonização europeia do mundo teve como combustível essa máxima: a carta branca para se apossar de terras por todos os continentes veio justamente da defesa da ideia da necessidade de a razão vencer a barbárie.

Concorreram para isso não apenas o racionalismo, mas também a fé, especialmente com a Igreja Católica e os movimentos de catequização do "novo mundo". Nesta ideia, a luz contra as trevas era também o da "verdadeira religião" contra os hereges. É a coexistência dessas duas figuras que vemos, voltando ao caso de Valença, na figura de padre Aguiar, católico e "teórico do progresso".

Durante o movimento de colonização de Valença, o discurso desempenha um papel crucial. A produção textual, como a que vimos acima com o padre Aguiar, se empenha em justificar o ato de usurpação, seja das terras, seja pelo abafamento de vidas e culturas locais.

Já que os novos habitantes ocuparam as terras se autoproclamando como iluminados pela verdade, faz sentido que o movimento de chegada às terras, no caso do período de habitação dos territórios colonizados, seja vista como um marco zero, algo como "expulsamos ou domamos os hereges, agora a verdadeira civilização pode começar".

É desta forma que, como Silva demonstra, fazendeiros que passaram a ocupar as terras valencianas são reconhecidos como os primeiros habitantes, sendo as qualidades destes construídas como "bravos", "corajosos" e com a iniciativa de erguer um marco civilizatório. Do outro lado, temos os habitantes que já ocupavam as terras e aqueles que vieram para o trabalho forçado. A relação de oposição levantada por esses povos (seja os nativos, seja, a partir desse momento, os africanos e seus descendentes escravizados), encontrava na racionalidade da verdade iluminista justificativa para uma contraofensiva de dominação.

Como possibilidade de investigar os territórios religiosos resistentes no espaço valenciano, a antropóloga Maria da Consolação Lucinda (2016) faz um recorte com abordagem na umbanda, tendo como foco as relações e participações 
sociais de seus praticantes na cidade. O livro de Lucinda, resultado de sua pesquisa de doutoramento em Antropologia Social da Universidade Federal do Rio de Janeiro, oferece análises sobre "práticas culturais e questões relativas à memória, vínculos hereditários e comunicação entre o mundo dos vivos, dos entes sobrenaturais e dos mortos" (contracapa). Lucinda, ao investigar e levantar uma análise etnográfica sobre o território religioso valenciano, sinaliza relações entre a umbanda e o catolicismo, identificando tensões e conflitos decorrentes de disputas políticas que mobilizam interesses destes dois segmentos.

Sobre a atuação da Igreja Católica no empreendimento colonial, evidenciando sua legitimidade política e social, Lucinda traz o depoimento do então pároco da Catedral de Nossa Senhora da Glória em 2006, padre Medoro, sobre a formação social da cidade. Recorto um trecho:

\begin{abstract}
Valença começa a ser invadida pelos colonizadores europeus, em 1797, finais do século XVIII, e em 1803, a iniciativa de Inácio de Souza Werneck, que era responsável pela chamada colonização da região, de pedir apoio da Igreja para fazer a catequese dos índios que começam a se rebelar contra a invasão branca. Todo simbolismo religioso que se pensava implantar inicialmente, ele era no sentido da coação espiritual como legitimação da atuação branca, ou seja, escolhe para Valença, como padroeira, Nossa Senhora da Glória. Então, essa sesmaria central decide construir a Matriz junto ao cemitério dos índios coroados [...] deram o nome de Nossa Senhora da Glória para ensinar o índio como se ensina no Outeiro da Glória, no Rio de Janeiro. $\mathrm{O}$ índio ou o negro que desobedecesse às ordens dos senhores [...] era decapitado e sua cabeça colocada nos postos em frente da igreja do Outeiro da Glória para servir de exemplo aos outros nativos e africanos que se rebelassem. $\mathrm{O}$ padre que é destinado para essa catequese [...] foi um profeta para a época porque desafiou o poder real do vice-rei D. Luiz (Lucinda, 2016, p. 52). ${ }^{10}$
\end{abstract}

O relato do pároco segue conciliando a relação que o Outeiro carioca e a catedral valenciana obtiveram, ilustrando a "atuação institucional, através de seus dispositivos de poder e aparatos disciplinadores, na conformação e organização do espaço social" (ibid., p. 52). O catecismo foi um recurso utilizado que gerou uma série de efeitos danosos, como quando, caso não funcionasse adequadamente em seu objetivo disciplinar, punições brutais e severas eram legitimadas. Desta forma, como já apontado, vemos como a institucionalidade católica e o colonialismo atuaram de forma articulada neste momento.

\footnotetext{
${ }^{10}$ Depoimento registrado em março de 2006 por Lucinda (2016).
} 
Voltando à análise de Silva, no que tange aos relatos dos principais agentes que ergueram a cidade - aqueles que realizaram as primeiras obras neste espaço, como os dois primeiros jardins públicos de Valença -, a memória dos escravizados é omitida e silenciada. Além disso, faz-se menção a uma realidade como se houvesse um "bom tratamento" perante a barbárie da realidade escravocrata, e o "bom tratamento dado a alguns negros escravizados surge neste discurso canônico como se fosse algo costumeiro" (Silva, 2014, p. 44). A autora frisa a importância de destacar que "também nestas narrativas há a tentativa de evidenciar os fazendeiros de Valença daquele século XIX como "bons senhores" (idem).

A autora nos mostra ainda, evocando mais uma vez o entrelaçamento entre religião e prática colonizadora iluminista, o papel desempenhado nesse momento pela noção cristã de caridade. Segundo a autora, havia um caráter estratégico nas homenagens prestadas aos grandes benfeitores fazendeiros, nobres, graças à sua benevolência para a sociedade valenciana. Nota-se que, antes de assegurar o que seria o suposto bem-estar produzido por estes "benfeitores", o ato de caridade na verdade entra em conflito com os moradores das terras locais que se recusaram a reconhecer Valença como uma categoria de cidade, pois isso significaria submeterse aos padrões civilizatórios e abdicar de seus costumes.

Em vez de atenuar o abismo colocado entre fazendeiros e o restante da população, a prática da caridade reforçaria esta diferença: por um lado, ao criar uma sociedade de benfeitores endinheirados que estabelece alianças entre si; por outro, por evocar uma atitude de assujeitamento por parte daqueles para quem a caridade é destinada, contribuindo para apaziguar a possibilidade de atitudes rebeldes.

A despeito da visão heroica, atrelada a figuras como a de militares monarquistas brasileiros por seus autos contra escravizados e investidos pelos "Barões do Café", figuras como a de Manoel Congo e de Maria Crioula se iluminam. Manoel Congo liderou e organizou junto com outros cativos um levante pela liberdade. No interior das matas da Serra da Estrela, conhecida como floresta de Santa Catarina, iniciaram a constituição de um quilombo elegendo Manoel Congo rei e Maria Crioula rainha. A história deste quilombo e seus líderes evidencia 
a luta e organização contra o regime colonial escravocrata na região do Vale do Paraíba. ${ }^{11}$

Mesmo no período em que o regime escravista se encontrava em declínio, o Brasil foi o país que mais resistiu, sendo o último a abolir a escravatura. Com os movimentos de libertação pelo país cada vez mais presentes, a Lei Áurea foi estabelecida somente em 1888. Com o declínio da produção cafeeira, a promoção da imigração de camponeses imigrantes - principalmente italianos - passou a ser incentivada. A vida dos recém-libertos de nenhuma maneira foi reparada de modo efetivo e a política de substituição de mão de obra imigrante passou a fazer parte do projeto da nova República que, no ano seguinte, 1889, se proclamava. É como afirma Abdias do Nascimento ao descrever tal fenômeno:

O "sistema" diretamente, e os imigrantes indiretamente, excluíram o povo negro, de maneira insensível e cruel, de qualquer oportunidade significativa de trabalho. Ambos, tanto o chamado "sistema de produção", quanto o proletariado-imigrante, se beneficiaram e cresceram à mercê da espoliação e do despojamento total do descendente africano (Nascimento, 1980. p. 19).

Essa tentativa de apagamento da população recém-liberta manteve o projeto civilizatório que visava massacrar e subalternizar populações. $\mathrm{O}$ incentivo para a vinda de imigrantes europeus para trabalhar nas lavouras de café teve como promoção uma política de branqueamento, fechando o mercado para exescravizados. Ainda assim, as condições exploratórias no modo de produção se mantinham. Diante do corroído cenário, a era do café passou. Como afirma Silva, "A 'Princesa da Serra', tornou-se pecuarista e laticinista" (Silva, 2014, p. 58).

Durante este período, o projeto civilizatório permaneceu atendendo e reconhecendo somente um grupo. Para dar conta do número ilimitado de sujeitos que "sobram" de acordo com o projeto ordenador colonial, Mbembe fala sobre a necessidade de eliminá-los como uma política de Estado. Dá a esse gesto o nome de necropolítica, conceito homólogo ao nome de seu livro (2018), expondo o processo de industrialização da morte, em embrião já no século XVII, cuja característica original consistia em "integrar a racionalidade instrumental com a

\footnotetext{
${ }^{11}$ Acesso a história de Manoel Congo e Mariana Crioula pelo portal Geledés. Disponível em: < https://www.geledes.org.br/a-saga-de-manoel-congo/>. Acesso em: 02 maio 2021.
} 
racionalidade produtiva e administrativa do mundo ocidental moderno" (Mbembe, 2018, p. 21).

Unindo a lógica produtiva das grandes indústrias e fábricas com a necessidade de eliminar parte da população, a necropolítica executa sujeitos de forma mecanizada. Este autor expõe como tal procedimento da racionalidade instrumental foi facilitado pelos estereótipos racistas fundamentados pela classe social, comparando "as classes trabalhadoras e os 'desamparados pelo Estado' do mundo industrial com os "selvagens" do mundo colonial" (ibid., p. 22).

Mbembe atualiza o conceito de biopoder de Foucault e expõe como a morte na modernidade, além de assumir um caráter "civilizador", passa também a atuar com procedimentos necessários para se "democratizar" os meios de eliminação dos inimigos do Estado.

Na necropolítica, a morte de determinadas populações é encarada como ação constituinte do sistema político, não como um infeliz incidente. As vidas matáveis devem ser descartadas para que a engrenagem social continue fluindo. O que Mbembe expõe é que a morte é componente necessário para manutenção de um sistema violento e sua opressão sobre determinados corpos. O grande lugar da formação de terror e concatenação da necropolítica foram as colônias, a escravidão, a plantation, os latifúndios. Mbembe mobiliza Frantz Fanon para pensar a forma de ocupação colonial dos agentes usurpadores, formas embrionárias do exercício da necropolítica. Como enfatiza o autor camaronês, tal ocupação se caracteriza por uma dominação do espaço, pelo retraçamento de limites e fronteiras e pela instalação de quartéis e delegacias, que passam a se comunicar com os colonizados através da linguagem da força. Segundo Fanon,

A cidade do colonizado [...] é um lugar de má fama, povoado por homens de má reputação. Lá eles nascem, pouco importa onde ou como; morrem lá, não importa onde ou como. É um mundo sem espaço; os homens vivem uns sobre os outros. A cidade do colonizado é uma cidade com fome, fome de pão, de sapatos, de carvão, de luz. A cidade do colonizado é uma vila agachada, uma cidade ajoelhada" (Fanon apud Mbembe, 2018, p. 41).

O autor mostra que a raça é, mais uma vez, crucial para esse encadeamento. Mbembe vai relacionar diretamente soberania com direito de matar através das noções de estado de sítio e estado de exceção. As terras colonizadas foram os 
espaços, em princípio, em estado de excepcional, onde as leis da colônia eram suspensas. Em certo momento, o que se entende como estado de exceção passa a ser compreendido como estado de regra. Ele aponta:

Como tal, as colônias são o local por excelência em que os controles e as garantias de ordem judicial podem ser suspensos - a zona em que a violência do estado de exceção supostamente opera a serviço da "civilização" (Mbembe, 2018, p. 35).

Em seu trabalho, Mbembe evidencia dois espaços geopolíticos: periferias e a centralidade do capitalismo. Gradativamente no desenvolvimento do capitalismo, afastam-se certos sujeitos para a periferia, avolumados em um excesso indesejado. O desenvolvimento de máquinas físicas e a automatização do trabalho requer então uma atuação do Estado para que continue funcionando, desta vez pela destruição massiva de corpos.

Política como trabalho de morte, a soberania como direito de matar, racismo, instrumentalização da morte: a necropolítica, no contexto da ocupação colonial tardia se manifesta em segregações e exclusões muitas vezes abafadas, como no caso valenciano. A condição irresolúvel de exceção promove permanentemente intervenções nos territórios e nos corpos dados como indesejados.

A reflexão de Mbembe nos permite pensar sobre o que nos assombra enquanto organização social em um Estado que herdou práticas coloniais. As “sobras", personificadas em seres considerados descartáveis, não se enquadram na lógica hiper mercantilizada, excludente e normativa do sistema. Não são apenas sujeitos que devem ser eliminados, mas culturas, formas de expressão religiosa, de comportamento, de vivência, cujo modo de existir entra em choque com o ritmo do desenvolvimento, do progresso, do mercado, ainda que essas sejam ideias forjadas em narrativas interessadas.

No entanto, em sua sobrevivência, o sujeito se depara com potências capazes de driblar a própria condição de exclusão ou, ao menos, de resistir à exigência de seu apagamento. Mbembe afirma que, apesar de considerar a vida de um escravizado em muitos aspectos como uma "morte em vida", "ele ou ela desenvolve compreensões alternativas sobre o tempo, sobre o trabalho e sobre si mesmo" (ibid., p. 30). 
Tal gesto designaria a capacidade de invenção e de manutenção da vida, a que os historiadores Luiz Antônio Simas e Luiz Rufino classificam como supravivência (Simas; Rufino, 2018, p. 101). Os sobreviventes podem virar "supraviventes" conceito por eles defendido para definir "aqueles que foram capazes de driblar a própria condição de exclusão (as sobras viventes), deixaram de ser apenas reativos ao outro (como sobreviventes) e foram além, inventando a vida como potência (supraviventes)" (ibid.). Invenção da vida essa que conta com múltiplas forças encantadas que possibilitam o "drible" existencial, indo na direção oposta da destruição e tomando como combustível as miudezas que atravessam temporalidades e espaços físicos.

Segundo Abdias do Nascimento, expressões religiosas ancestrais mantiveram-se resistentes, mesmo diante de tentativas, sutis ou violentas, de destruição colonial. Como afirma o autor:

\begin{abstract}
Agredidos de todos os lados, foi em suas religiões ancestrais que o africano encontrou um espaço onde se apoiar e defender o que the restava de identidade humana. E, cientes desse fato, tanto a sociedade institucionalizada como a religião oficial do Estado, o catolicismo durante o período colonial, não deram tréguas às religiões vindas da África. Acusadas de cultos fetichistas, sofriam a condenação dos sacerdotes católicos e a repressão policial. Mas a verdade é que a despeito da manipulação de tantas estratégias e recursos para degradar, distorcer e esmagar a herança africana, a cultura convencionalmente tida como a dominante careceu de aptidão para concretizar os objetivos que perseguia. Não conseguiu suprimir completamente os valores africanos de cultura. Instituições e tradições de diversas culturas transplantadas da África para o Brasil permanecem existindo em todo o seu brilho e vitalidade (Nascimento, 1980, p. 89).
\end{abstract}

No fenômeno trágico que passou a ser conhecido como diáspora africana, línguas, culturas, crenças de diferentes locais africanos passaram a habitar também em terras brasileiras. Assim, junto ao projeto de civilização da sociedade valenciana, certas culturas a princípio designadas apenas no caminho da eliminação adotaram estratégias de permanência.

Foi assim que se fincaram também valores, culturas, hábitos, crenças, danças, batuques, cantigas, rezas e costumes. Para a reflexão do conceito de "supravivência", Simas e Rufino tensionam a noção de humanidade, valorizada nos discursos do paradigma científico ocidental, deslocada para a noção de encantamento e desencantamento. Segundo eles: 
Tudo que há no universo está sobre essas dinâmicas, porém essa condição é compreendida não nos limites de vida e morte das tradições ocidentais. Para parte dos saberes negro-africanos e ameríndios, significados nas bandas de cá do Atlântico, as noções de encantamento e desencantamento ou vivo e não vivo estariam ligadas à capacidade de manutenção de energia vital ou na não detenção dessa energia. Um ancestral de um determinado grupo, mesmo na condição do que conhecemos como desencarnado, ocupa uma condição de vivo, uma vez que interage, é lembrado, é reverenciado e participa das dinâmicas da vida e do cotidiano daquele grupo. Nesse caso, a condição de não vivo estaria vinculada ao esquecimento. Ou seja, perda de potência (Simas; Rufino, 2018, p. 30).

A dimensão do encantamento e seu inverso é posta em perspectiva para tudo que compõe a vida e as suas interações no mundo. Além de animais, pessoas, minerais e plantas, a palavra também é encarnada como força que está vinculada à ciência encantada. $\mathrm{O}$ valor ancestral é princípio fundante da manutenção da vida e revitalização do ser. Na possibilidade de leitura, os autores sugerem o reconhecimento das múltiplas perspectivas ontológicas, epistemológicas, cosmogônicas e filosóficas fora do eixo de julgamento ocidental europeu. Há de se credibilizar "as inúmeras formas de experiências, principalmente aquelas não possíveis no colonialismo ocidental, como mantenedoras e produtoras de saber" (ibid., p. 31).

Voltando aos nossos instrumentos teóricos mobilizados para ajudar a pensar o caso de Valença, podemos evocar, junto com Santos, a demarcação polarizadora do pensamento abissal atuante nesse momento através de diversas oposições totalizantes. A principal delas é a que opôs civilização a barbárie, classificação que, na prática, buscou conferir dignidade a um grupo restrito de pessoas como ocupantes da terra, a que mereceriam ficar.

Santos avalia que colonialismo e modernidade são duas faces da mesma moeda. Faz sentido, seguindo esta compreensão, o fato de que a cidade de Valença localize seu marco identitário no gesto de apossamento da terra pela sociedade cafeeira, encontrando aí a imagem de sua glória fundadora.

Já que esta é uma violência auxiliada por um discurso legitimador, sua crítica requer, como uma das estratégias de enfrentamento, uma revisão das formas de escrita e compreensão textual. O próprio fato de que, tal como pontuamos no início do capítulo, estes conflitos apareçam nas entrelinhas da fala hegemônica já é uma das marcas dessa revisão. No entanto, juntamente com esta análise textual, 
pergunta-se também pela possibilidade de reescrever novos enunciados da história, buscando manter ativa as vozes resistentes às tentativas de silenciamentos.

Um dos conceitos atuais que nos permite encontrar brechas nessa direção é o de fronteira desenvolvido, dentre outros autores, por Lemos (2016) a partir de uma proposição de $\operatorname{Costa}^{12}$. No entanto, pensar a ideia de fronteira requer considerá-la como algo distinto do que uma simples demarcação geográfica restrita, compreensão expressa na fala de Mbembe:

Já não passa claramente por alargar o círculo, mas por tornar as fronteiras formas primitivas para afastar inimigos, intrusos e estrangeiros - todos aqueles que não são dos nossos. Num mundo mais do que nunca caracterizado pela desigualdade no acesso à mobilidade e onde, para muitos, o movimento e a circulação são a única hipótese de sobreviver, a brutalidade das fronteiras é agora um dado fundamental do nosso tempo. As fronteiras deixam de ser lugares que ultrapassamos, para serem linhas que separam. Nestes espaços mais ou menos miniaturizados e militarizados, tudo se deve imobilizar (Mbembe, 2017, p.10).

Neste sentido restritivo de fronteira, temos, por trás da aparente neutralidade de delimitações geográficas, uma chamada ao conflito, ao apossamento, ao levante militar e policial, formas de garantir a validade das demarcações. Por outro lado, mais do que conferir limites a cada território, Lemos mobiliza uma compreensão de fronteira como a maneira de cada sociedade criar modos de vida e, através disso, traçar uma relação com o espaço em que cabem múltiplas singularidades.

Trazer à cena esta concepção de fronteira, colocando-a em confronto com o discurso hegemônico como o apontado no caso de Valença, possibilita um esforço de ir ao encontro das vidas atropeladas pela história oficial. Também busca construir uma ideia não excludente de comum.

É importante atentar para o fato de que o gesto de distinguir essas linhas demarcatórias de produção de vida através da ideia de fronteira não significa eliminar a diferença, mas antes defendê-la. Não se trata, tal como encontramos em textos como o do padre Aguiar, de falar pelo "bem da nação", traçando um plano geral de funcionamento mais eficiente da sociedade. Fronteira assume aqui o sentido "do limite entre duas sociedades na qual uma se expressa de uma forma diferente da outra nos territórios que exercem o seu modo de produção da vida"

\footnotetext{
${ }^{12}$ Costa, Wanderley M. O Estado e as Políticas Territoriais no Brasil. São Paulo: Contexto, 1991, p.18.
} 
(ibid. p. 28). Ao invés do uno, da ordem, do progresso, fronteira é o espaço comum de coexistência do múltiplo.

Além disso, como alternativa ao pensamento abissal e sua obsessão pelas divisões dicotômicas, Santos levanta a possibilidade de um pensamento pós-abissal, que pressupõe a aceitação de outras formas de saber, o reconhecimento e a inclusão de sua importância perante a sociedade. Seguindo esta proposta, o autor apresenta a ecologia de saberes:

Como ecologia de saberes, o pensamento pós-abissal tem por premissa a ideia da inesgotável diversidade epistemológica do mundo, o reconhecimento da existência de uma pluralidade de formas de conhecimento além do conhecimento científico. Isso implica renunciar a qualquer epistemologia geral. Existem em todo o mundo não só diversas formas de conhecimento da matéria, da sociedade, da vida e do espírito, mas também muitos e diversos conceitos e critérios sobre o que conta como conhecimento (Santos, 2009, p. 45).

Outro termo importante para esta reflexão é o de Alexandre Montaury (2019), ao apontar para a ideia de uma "coabitação epistêmica", que seja inerente e radical como garantia da possibilidade de pensar diferente, viver de outra maneira e se relacionar de outra forma com o mundo.

Mbembe, sob a luz de Fanon, elabora o gesto de cuidar "uma prática de ressimbolização, na qual reside a possível reciprocidade e mutualidade (o encontro autêntico com o outro)" (Mbembe, 2017, p. 12):

Ao oprimido que procurava desembaraçar-se do peso da raça, Fanon propôs, assim, um longo caminho de cura. Tal cura começava pela e na linguagem e na percepção, pelo conhecimento da realidade fundamental, segundo a qual tornar-se homem no mundo era aceitar ser exposto ao outro. A cura prosseguia por um colossal trabalho consigo próprio, por novas experiências do corpo, de movimento, de estar-junto (isto é, de comunhão), como fundo comum que o homem tem de mais vivo e de mais vulnerável, e continuava ainda pelo eventual exercício da violência. Violência dirigida contra o sistema colonial. Uma das particularidades deste sistema era produzir uma gama de sofrimentos que não desencadeavam como resposta nem tomada de responsabilidade, nem solicitude, nem simpatia e nem sequer piedade. Pelo contrário, fazia-se tudo para atenuar todo e qualquer compadecimento ou afetação pelo sofrimento dos indígenas. Além disso, a violência colonial tinha por função captar a força do desejo no subalterno e desviá-la para investimentos improdutivos. Fingindo querer o bem do indígena, o aparelho colonial pretendia não só travar o seu desejo de viver, mas também visava atingir e diminuir as suas capacidades de autoestima como agente moral (Mbembe, 2017, p. 13). 
Assim, Mbembe prossegue, afirmando que a doença que assalta as subjetividades era o "homem sem família, sem amor, sem relações humanas e sem comunhão com uma comunidade". (ibid., p. 14) A não partilha, a priori, de laços que ligam esses sujeitos - e que não aspiram estar perto dos outros, é ainda uma realidade.

A análise de Lucinda a que referimos anteriormente aponta como os territórios de ancestralidades negras valencianas também devem ser percorridos por fluxos, levando em conta as diferentes memórias e os movimentos de variação contínua entre elas. Esses fluxos, não apenas "históricos", que pressupõem um polo primitivo até a modernidade, são "devires, forças de resistência, que ora compõem com as forças dominantes, ora a elas se opõem de forma intransigente" (Lucinda, 2016, p. 21).

A autora rememora, por exemplo, a participação de escravizados e alforriados na construção da sociedade, desde a organização do aldeamento e a construção dos prédios públicos, no ingresso forçado ao trabalho na lavoura cafeeira e a "conjugação de fluxos e desejos que resultaram na edificação da Capela do Rosário" (Lucinda, 2016. p. 53). A Igreja de Nossa Senhora do Rosário é um marco devido à importância da devoção à santa desde a tradição católica africana, "que teria sido introduzida na África pelos dominicanos durante missões de catequese ainda no século XVI" (Simas, 2018, p.18). As congadas $^{13}$, com as especificidades de cada região no Brasil, são tradições que trazem elementos também desta devoção ao homenagear Nossa Senhora do Rosário e São Benedito. A ausência de registros sobre as irmandades ${ }^{14}$ que levaram à criação da capela, e a personificação da imagem de um escravizado de nome Miguel Tomaz, que havia sido alforriado e reivindicado o surgimento da capela, é mais uma tentativa de abafar o caráter

\footnotetext{
${ }^{13}$ As congadas são autos dramáticos tradicionais, definidas por Simas como "ao mesmo tempo que recria a cerimônia de coroação do rei do Congo e da mítica rainha Jinga de Angola, com suas cortes respectivas, o folguedo dramatiza a luta entre mouros e cristãos, com a vitória dos últimos. Homenageia, ainda, Nossa Senhora do Rosário e São Benedito, entre cantos embalados por tambores, pandeiros, sanfonas, reco-recos, violas, violões e cavaquinhos" (Simas, 2018, p. 17).

${ }^{14}$ Sobre as irmandades, Abdias Nascimento afirma: "Outro tanto sucedia com as fraternidades religiosas cuja origem se encontra na discriminação racial da Igreja Católica contra os africanos. Instituídas por razões bem diferentes, as irmandades de N. S. do Rosário, de São Benedito, e outras, obedeciam certa divisão étnica que contribuiu para o fortalecimento dos respectivos grupos, nos centros urbanos (Nascimento, 1980, p. 90).
} 
estratégico de mobilização coletiva. A capela, que também constitui o Memorial Afro-Valenciano Padre João José da Rocha, é um exemplo disso.

Em sua investigação, Lucinda promove uma reflexão de como, mesmo com adaptações e recriações, as práticas e os elementos do repertório cultural acionado pela Irmandade do Rosário podem, em certa medida, ser observadas em experiências como a umbanda. "O exemplo emblemático disto é o Caxambu e o uso do Rosário na celebração do Terço. Daí a inferência de que o florescimento da umbanda na cidade tem como um de seus motores o tipo de catolicismo praticado na cidade em tempos já imemoriais, que absorveu elementos do repertório religioso de matriz afro-brasileira" (Lucinda, 2016. p. 65).

Já o estudo de Silva, ao analisar o conteúdo do Jornal Local, conclui que o atual periódico da cidade de Valença persiste reverberando a ideia de uma identidade valenciana possuidora de um passado fenomenal, esplendoroso. No entanto, por vezes, pode ser reconhecida no texto do jornal críticas a essa ideia de mito originário, especialmente, como aponta a autora, quando a remissão a esse passado identitário glorioso se coloca contra a ideia de progresso:

Apesar de, como comprovado em nossas averiguações, o Jornal Local possuir um discurso conservador em relação à identidade valenciana, algumas raras vezes, o discurso do impresso critica "os profetas dos velhos tempos", que, com sua postura retrógrada, se colocam contra as mudanças nos cenários político, econômico e social valenciano, atravancando assim o desenvolvimento da cidade (ibid., p. 144).

Ainda em seu estudo, a autora traz um apontamento a respeito da festividade de grande destaque na cidade, popularmente conhecida como "Festa da Glória":

Houve ainda algumas outras constatações que merecem ser enumeradas. A primeira delas é que, pelo número de textos destinados a falar sobre a Festa de Nossa Senhora da Glória, podemos concluir que esta é um dos marcos narrativos e históricos mais importantes para a formação da identidade valenciana tradicional, visto que foi tema de considerável número de textos das edições analisadas do JL (Jornal Local). Nesse sentido, vale salientar ainda que esta comemoração é muito mais relevante do que o próprio aniversário da cidade, assunto pouco abordado no impresso em foco, apesar de ter acontecido em data inserida no período em que realizamos a análise do periódico (Silva, 2014, p. 147).

A festa da padroeira da cidade se estende por aproximadamente duas semanas e é um período que marca uma das principais festividades do município ainda em sua atualidade. Além de toda a programação litúrgica, a festa conta com apoio de 
muitos produtores locais, com "barraquinhas" e shows. A festividade é dinamizada, reinventada a partir da fé singular, rompendo as fronteiras entre o sagrado e profano, o que Simas $(2018$, p. 30) aponta como característica de muitas festividades populares nacionais, em que num mesmo terreno da fé, certas representações, como a da padroeira da cidade, passam a dissolver contornos rígidos de demarcação e ativar múltiplas forças.

Junto a esses exemplos, é possível destacar exemplos em que a fé proveniente do território religioso valenciano foi invocada para a glória em seu sentido expandido, como a partir do relato de Clementina de Jesus, valenciana, sobre sua consagração pública enquanto cantora. $\mathrm{O}$ encontro de Clementina com o produtor, poeta e compositor Hermínio Bello de Carvalho se deu aos pés da ladeira do outeiro da Glória, no Rio de Janeiro. Segundo Castro et al., "da Taberna da Glória, a voz densa de uma mulher cortava o ambiente, fazendo o poeta se perguntar se já havia escutado aquilo antes. Já tinha sim" (Castro et al., 2017, p. 9).

Clementina, com sua devoção a Nossa Senhora da Glória, no dia da festividade do mês de agosto, mantinha sua tradição em celebrar as glórias da santa. Graças a esse rito anual, Hermínio pode reencontrar a cantora, a quem havia visto e escutado um ano antes. Glória à rainha Quelé.

Há algo de inusitado nesses apontamentos. Ainda que a religião católica, como instituição, tenha atuado juntamente com os dispositivos colonizadores, existem brechas de resistências abertas não fora e contra ela, mas em seu interior. Para nossa tradição herdeira da modernidade ocidental, acostumada com oposições dicotômicas, tal possibilidade parece um paradoxo. Neste momento, acompanhamos a pergunta de Homi Bhabha: "Será preciso sempre polarizar para polemizar?” (Bhabha, 1998, p. 43).

Uma análise cuidadosa deve ser capaz de captar a sutileza dos acontecimentos, esbarrando muitas vezes em nossa obstinação a reconhecer resistências que acontecem a partir de misturas não categorizadas em sistemas dicotômicos. Desta forma, ainda que pretendêssemos levantar uma firme oposição à participação da religião católica no espaço valenciano, a própria prática estaria nos desmentindo. 
É o que acontece em certos espaços aparentemente rígidos e estanques por dogmas, como é o caso da dimensão da fé. Ainda que faça parte da "máquina de assentamento eurocêntrica", o próprio repertório da religião católica, ao ser sincretizada frente às formas de opressão, cria brechas subversivas em estratégias de driblar a exclusão pelas práticas de muitos fiés.

É nesse sentido que este estudo visa o reconhecimento de ancestralidades herdadas que, em suas diversidades amalgamadas, com seus valores, conjuntos de crenças, costumes e línguas, seguem produzindo a manutenção da vida com seus praticantes. São múltiplos jeitos de cantar, rezar, benzer, comer, louvar a natureza e os ancestrais. Formas de vida que resistem a tentativas sistemáticas de eliminação e seguem em seus sistemas de organização comunitária e de invenção da vida.

$\mathrm{O}$ reconhecimento e respeito das diversas ancestralidades atuantes no território cotidiano local já é um importante passo para combater as múltiplas desigualdades que precisam ser combatidas, mas não só. Vislumbramos a criação de diversas narrativas, laços e redes comunitárias estratégicas. Espaços de resistência que adquirem seus contornos livres de sujeições aniquiladoras, tal como são, por exemplo, quilombos e aquilombamentos - espaço de articulação, estratégias, manutenção de tradições e fortalecimento em coletividade. Falando sobre o caso de Valença e sobre os propósitos desta dissertação, nossa análise toma corpo com o caso específico do quilombo São José da Serra.

\section{2. \\ Relendo a contrapelo: aquilombamentos em prol da vida}

O Quilombo São José da Serra, o mais antigo do estado do Rio de Janeiro, se encontra nos arredores da Serra da Beleza em Santa Isabel do Rio Preto, distrito do município de Valença. É formado por uma grande comunidade familiar, com cerca de duzentos quilombolas descendentes de africanos provenientes do Congo, de Moçambique e principalmente de Angola (Silva, 2016). Segundo a Fundação 
Cultural Palmares ${ }^{15}$, o local se tornou um quilombo abolicionista e faz parte de um universo quilombola de quarenta e duas comunidades no estado.

Em seu terreiro, além das manifestações de cunho religioso, estão presentes rodas de jongo, rodas de capoeira, folia de reis, entre outras. O fazer jongueiro da comunidade do quilombo São José da Serra é reconhecido desde 2005 pelo Conselho Consultivo do Instituto do Patrimônio Histórico e Artístico Nacional (Iphan) como patrimônio imaterial e registrado no Livro das Formas de Expressão ${ }^{16}$ (Silva, 2016). A agricultura de subsistência familiar faz parte do cotidiano dos moradores. Na comunidade quilombola São José da Serra é mantida uma série de conhecimentos que visam à manutenção da vida, suas organizações sociais e o meio ambiente. Pesquisas como a de Rocha (2014) reconhecem a importância das plantas para manutenção do modo de vida da população local e as diversas contribuições sobre o etnoconhecimento mantido por eles há gerações.

Duas festas anuais fazem parte do calendário oficial do local: a Festa de Preto Velho, celebrado no dia 13 de maio, dia de São Benedito; e o dia 20 de novembro, marcado pelo Dia Nacional da Consciência Negra, dia de Zumbi. As festividades fazem parte do Mapa da Cultura do Rio de Janeiro, quando, aberto ao público, seus moradores reafirmam suas tradições e rememoram histórias. Porém, no ano de 2019, as festividades foram canceladas pelos organizadores do próprio local, uma decisão sob justificativa da manutenção das tradições e assegurar seus costumes ${ }^{17}$.

Para seguir com a reflexão a respeito dos conhecimentos e narrativas no território quilombola, o pensamento de Beatriz Nascimento (1977, 1982,1985) é de suma importância. A pesquisa e militância de Beatriz consiste na produção de outras imagens não estereotipadas dos quilombos, tratando-os como um sistema

\footnotetext{
${ }^{15}$ Disponível em: < http://www.palmares.gov.br/?page id=37551>. Acesso em: 02 abr. 2021

${ }^{16}$ A partir da definição do Instituto do Patrimônio Histórico e Artístico Nacional (Iphan), "O Livro de Registro das Formas de Expressão é o instrumento utilizado pelo Iphan para registrar manifestações artísticas brasileiras protegidas como Patrimônio Cultural do Brasil. Estas são as múltiplas formas de comunicação reconhecidas e associadas a determinado grupo social ou região, desenvolvidas por atores sociais reconhecidos pela comunidade e em relação às quais o costume define normas, expectativas e padrões de qualidade. Trata-se da apreensão das performances culturais de grupos sociais, como manifestações literárias, musicais, plásticas, cênicas e lúdicas, que são por eles consideradas importantes para a sua cultura, memória e identidade." Disponível em: < http://portal.iphan.gov.br/fototeca/detalhes/13/fototeca-registro-das-formas-de-expressao $>$. Acesso em: 02 abr. 2021.

${ }^{17}$ Em nota nas redes sociais, a preocupação apresentada foi a de manter as tradições e características particulares da comunidade.
} 
antissistêmico, uma instituição social afro referenciada contra as formas de opressão, que defende a continuidade da vida e a liberdade do povo negro:

A continuidade seria a vida do homem - e dos homens - continuando aparentemente sem clivagens, embora achatada pelos vários processos e formas de dominação, subordinação, dominância e subserviência. Processo que aconteceu, ao longo desses anos, com aqueles que, em nossas abstrações, se englobam na categoria de negros (Nascimento, in: Ratts, 2006, p. 108).

Em seus textos, a autora faz uma defesa da potencialidade de indivíduos cujas ações criadoras se dão neste espaço de micropolítica. Nascimento elabora a sua tese a partir da ideia de desterritorialização e territorialização, no caso, dos indivíduos negros, aprofundando e defendendo a ideia de que entender as minorias como um bloco monolítico é prejudicial na luta da subjetivação.

Beatriz Nascimento, ao iniciar seu artigo Kilombo e memória comunitária: um estudo de caso (1982), destaca a tecnologia da comunicação oral e a possibilidade de organização ao falar sobre os quilombos brasileiros. A autora inicia o argumento de seu trabalho partindo da indecisão pelas múltiplas formas que o título poderia levar: "Gostaria de dar a este trabalho o título de 'A memória ou a oralidade histórica como instrumento de coesão grupal', ou ainda 'A memória e a esperança de recuperação do poder usurpado'." (Nascimento, In: Ratts, 2006, p. 109). Nascimento enfatiza a necessidade de se pensar o quilombo em seu cotidiano, humanizando sujeitos quilombolas. "Cientificamente falando, pretendemos demonstrar que os homens e seus grupamentos, que formaram no passado o que se convencionou chamar "quilombos", ainda podem e procuram fazê-los" (idem).

A historiadora joga luz também sobre as fronteiras, em sua posição geográfica:

É muito comum encontrar no Brasil - mas o vimos também em Angola - os quilombos se localizando em planaltos ou colinas, nas proximidades de rios, ou outros caminhos naturais, possuindo clima bastante específico, onde as condições do Sol e de outros astros dão uma sensação de espaço aberto, diríamos, oceânica e infinito. Figura, por isso, a características de fronteira, não só geográfica, como também demográfica, econômica e cultural que estas organizações possuem (ibid., p. 115).

Nascimento busca trazer a história concreta sobre o que foi o quilombo a partir da perspectiva de seus habitantes. Antes de mais nada, quilombo é a 
organização de uma sociedade para si, onde é possível viver de acordo com seu passado histórico, em reafirmação de suas africanidades e tradições constituintes. Daí, sua importância em trazer elementos desde Angola, envolvendo costumes, hábitos, cultura e forma de ser.

Sobre o caráter pacífico de alguns quilombos, e aqui trazemos um paralelo com o quilombo São José da Serra, a autora afirma que:

[...] tanto no século XVII quanto no século XIX, esta instituição procede como frinchas no sistema, muitas vezes convivendo pacificamente, que ao ser vista globalmente, ou seja, em todo o espaço territorial e em todo o tempo histórico, traduzia uma instabilidade inerente ao sistema escravagista" (ibid., p. 122).

Os quilombos são, portanto, espaços de resistência, locais que cultivam e enaltecem modos de vida. Para se aproximar da ótica que pretende defender, a historiadora busca fugir do conceito abstrato de quilombo, contextualizando-o na vida cotidiana de seus habitantes. A autora evita assim apoiar sua reflexão a partir do ponto de vista de precariedade econômica da população quilombola, evocando, além dos sistemas de opressão, práticas cotidianas de subjetivação, de criação e cultivo de modos de manutenção da vida.

Nos quilombos, em oposição à perspectiva de embate, repressão, de formulação de nação como o status quo, Beatriz constrói um olhar que enaltece o diálogo entre seus integrantes, estudos geográficos, tradições, técnicas de plantio, estratégias em prol da vida, seu caráter estratégico militar para defesa e afirmação. Delineia, portanto, o papel ideológico do quilombo e da necessidade de pensá-lo em seu cotidiano, humanizando os sujeitos quilombolas.

Para trazer as narrativas do quilombo ao qual nos referimos, trago algumas falas do documentário Quilombo São José da Serra ${ }^{18}$, de Luiz Fernando Sarmento. Antônio Nascimento Fernandes, o Toninho Canecão, líder e atual representante do Quilombo São José da Serra, inicia a sua fala no documentário ressaltando que a formação deste quilombo foi planejada em comunidade com o fazendeiro da fazenda de mesmo nome e que viria a ser um lugar de pacificidade pós-abolição. Mas, com a valorização da pecuária e a cobiça pela terra, o acordo "de boca" que

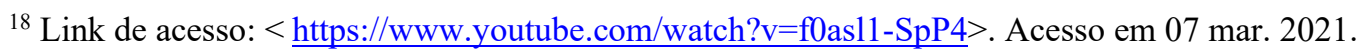


havia sido garantido na palavra do fazendeiro com os quilombolas foi "de água abaixo".

A luta pela permanência das terras ainda não havia sido garantida na época da produção do documentário. O reconhecimento e titularidade do espaço foi definitivo aos quilombolas do Quilombo São José da Serra somente em 2015, quando recebeu do Incra a Concessão de Direito Real de Uso (CDRU) de seu território tradicional. A garantia à posse da terra é um direito adquirido pelos quilombolas desde a Constituição Brasileira de 1988. "Os antepassados criaram o espaço para a criação de cavalo, cabrito e criação familiar", declarou Toninho ao documentário, complementando a resistência de seus antepassados. Em outro trecho, o líder local faz referência ao Jequitibá em torno da permanência. "É preciso plantar pra ficar."

"Eu nasci aqui no grutão", afirma Toninho Canecão, recordando sua história e a memória de quem viveu no período colonial. Seu avô, que ainda havia vivido nos tempos da escravidão, logo quando começou a ficar cego, pediu para que Toninho fosse criado junto a ele. Para que pudesse ser hoje o líder local, valores e conhecimentos seriam transmitidos no cotidiano de sua criação. Toninho destaca como costumes africanos como o valor da comunidade, respeito aos mais velhos, à tradição mantida herdada da oralidade e à ancestralidade é o que mantém a união do quilombo: "aqui, antiguidade é um posto muito respeitado. Hoje, apesar de ter esclarecimento lá de fora, da modernidade de alguma coisa, quando o mais velho fala, aquilo vira lei".

A conexão com as matrizes africanas é compreendida e revitalizada pela pluralidade. O jongo é uma das tradições que simboliza um dos legados deixados. Como afirma Carmo, "o jongo, inicialmente praticado pelos escravos de origem bantu $^{19}$ que trabalhavam nas fazendas do Vale do Paraíba, é uma manifestação cultural entendida enquanto dança e gênero musical poético" (Carmo, 2012, p. 12). Ao traçar as narrativas produzidas no quilombo São José da Serra, não se espera esgotar ou partir de categorias definitivas.

\footnotetext{
${ }^{19}$ Mesmo quando se fala em bantos, não se fala em um só povo. Bantu é um conjunto de etnias, com um mesmo tronco linguístico que os identifica. O sagrado é um forte eixo para as culturas bantas, assim como em outras matrizes culturais africanas que sustentam a fé na divina criação dos mundos. Makota Valdina (2010), na série Mojubá, parte da cosmogonia banta sobre a existência de dois mundos, um visível e outro invisível, e na interação entre esses dois mundos.
} 
O líder quilombola, em outro trecho do documentário, revela os fundamentos civilizatórios que mantêm a comunidade do Quilombo São José da Serra. "O jongo, pra nós aqui, é como se fosse o carro-chefe. Porque antes da gente aprender o Pai Nosso, a gente já sabia cantar o jongo". Sobre a força e centralidade do jongo para os quilombolas do local, Toninho afirma ainda:

A força do quilombo é o negro, a união e o jongo. E o jongo, é o início, é o meio e a permanência, não vou dizer fim não, porque tudo que gira em torno do quilombo, gira em torno do jongo. Igual a gente, tá fazendo a busca pela terra, a gente quer a conquista da terra, mas porque a gente quer a terra? Pra gente manter a nossa cultura aqui dentro, esse é o nosso maior desejo, que a gente não se perca. Hoje no quilombo, a criança antes de ser batizado lá na igreja ele é batizado na roda de jongo. Então a gente tem muito respeito com o jongo.

É possível observar como o jongo aparece enquanto instrumento de força na coesão grupal para os moradores da comunidade quilombola São José da Serra. A sua manifestação é, como se nota nos depoimentos gravados, lembrada como tradição de suma importância. Toninho, ao lembrar de um jongo cantado ("Ô gente, nasci n'Angola, Angola que me criou. Eu sou neto de Moçambique, ô gente... Eu sou negro sim sinhô"), conta:

Esse jongo aí é a confirmação da relação do nosso povo com Angola, que a gente, apesar de morar aqui, de não ter conhecimento da cultura geograficamente, mas a gente sabia que o nosso povo veio da região do Congo e de Angola, então nós cantávamos muito esse jongo, porque foi na lavoura de café, aqui na nossa região, que já cantavam esse jongo.

Toninho relata ainda a potencialidade do jongo enquanto fonte de agrupamento e de comunicação entre os africanos levados para as lavouras de café. Um dos ensinamentos herdados de seu avô explicam o porquê:

Quando começou a escravidão no Brasil, o negro vinha de várias tribos ali da região de Angola, Congo e outros lugares mais. Então o jongo era a maneira de se comunicarem. O jongo cantado na lavoura de café dava ao negro a oportunidade de descansar. Porque o feitor, meu avô falava, ficava correndo a leira do café. A leira era uma rua que do pé você via o cara trabalhando lá em cima. O negro começava a cantar de acordo que o feitor passava, ia cantando mais alto, e o feitor passando e eles cantando mais alto, mais alto. Quando o feitor vinha voltando, eles iam cantando mais alto. Enquanto uns cantavam mais alto, os de lá de trás tavam descansando, escorando na enxada, e aí ele não ouvia o barulho da enxada. Foi uma maneira também de enganar o feitor. Então, o jongo é um bem que a gente tem. Inclusive, cura até doença na roda de jongo. Quando estamos muito carregados, a gente fala de força negativa, então eles faziam a roda de jongo e dentro da roda de jongo íamos 
descarregar aquele fluído ruim, que a gente tinha adquirido pelo olhar de alguém ou outra coisa assim.

A partir dessa fala de Toninho, é possível afirmar como o jongo é uma manifestação religiosa de força, coesão e de transmissão de valores para os quilombolas da região valenciana. Mas é importante tensionar a reflexão de Toninho. Ao fugir de rotas reducionistas, cito Carmo,

Ao considerar, pois, que o jongo se insere num campo cultural de interações e contradições, deve-se excluir tanto a possibilidade de uma homogeneidade do jongo praticado pelos diversos grupos, quanto a busca por uma autenticidade desta expressão cultural nas comunidades jongueiras consideradas tradicionais. Devem ser considerados também os modos de manutenção dessa tradição, além das tensões e negociações que envolvem o processo de construção de suas representações e revelam elementos de contraste entre esses grupos, afirmando a identidade de cada um deles. Um desses elementos é a percepção diferenciada das comunidades jongueiras sobre a relação da religiosidade - católica e de matrizes africanas - com o jongo (2012, p. 38).

Diferentes formas de celebrar e cultuar as manifestações do sagrado foram preservadas e dinamizadas - o solo, o espaço nativo, bater o pé no terreiro possibilita o fortalecimento e o resgate na celebração do território.

O vínculo com as tradições religiosas é continuamente atualizado e reforçado também através de rezas transmitidas por gerações. Sobre sua religiosidade, a coleção Terras de Quilombos, em parceria entre INCRA, CGPCT e NEAD (MDA) e UFMG, fez uma publicação que conta com um material feito com diversos colaboradores e nos fornece dados acerca do quilombo São José. É possível perceber como o território religioso é reconhecido e recorrido por muitos como meio de buscar auxílios:

Outro marco cultural de São José da Serra, o mais antigo quilombo do Estado do Rio de Janeiro, é a religiosidade de seus moradores, que são católicos e umbandistas. As mães de santo da comunidade, famosas em todo o Rio de Janeiro, são procuradas por pessoas das mais diversas origens sociais em busca de consolo e de auxílio espiritual. "Vem gente do Rio, gente de Valença, vem um bocado de gente de todo lado", contou o Sr. Manoel Seabra em entrevista no fim da década de 1990. "A chefe aí é só ela, eu sou o ajudante", disse na ocasião, referindo-se a sua irmã Dona Zeferina do Nascimento. "Ela é em primeiro lugar, depois somos nós. É ela que comanda." Mãe Zeferina, ou Mãe Firina, como também era conhecida, nasceu nos anos 1920 e por décadas foi a líder espiritual de São José da Serra, tendo legado seu terreiro a Terezinha Fernandes de Azedias, de 71 anos (Silva, 2016. p. 3). 
Os princípios da comunidade refletem também, enquanto legado, as heranças do território do quilombo São José da Serra. O Jequitibá, a partir da referência trazida por Silva, diz respeito à conexão dos quilombolas com os povos originários que também viviam no local. Ele grafa:

Além dos terreiros, outro local sagrado da comunidade é a pedreira onde vive uma centenária e gigantesca árvore de jequitibá. Segundo os moradores mais velhos de São José da Serra, o lugar foi morada de índios e mais tarde foi usado como abrigo por seus antepassados. "É como se fosse nossa matriarca, um refúgio de fortaleza. Quando alguém tem alguma doença, vem rezar e é atendido", diz Dona Maria Santinha do Nascimento Roque. Sob a copa da árvore há grutas, ossos e raízes aparentes. "A gente vê a imagem dos índios na pedra", diz Dona Maria Santinha, mais conhecida como Santinha Sarapião (ibid., p. 4).

Mãe Terezinha Fernandes de Azedias, conhecida como "Tetê", é também benzedeira no quilombo. Segundo seu depoimento no documentário, antes de assumir o comando do terreiro da comunidade, trabalhou 31 anos ao lado da mãe. Segundo ela, a tradição e os costumes têm seus fundamentos e devem ser cumpridos à risca para que nenhum conhecimento seja extraviado. "Toda vida, desde criança, eu fui vidente. Metade sumiu, porque não liguei que eu tinha a vidência. Mas qualquer coisa que tava pra acontecer, e acontecia a distância que fosse, eu sabia." Sobre a relação sagrada com a natureza, "Tetê" prossegue em seu relato:

O sentimento que a gente sente é pela Mãe d'Ouro que a gente sempre vê. A gente sempre respeita - o nosso pé de Jequitibá e o centro espírita Umbanda Sagrada também. Ela sai da pedra e ilumina a gente. Batia caixa na água e escutávamos. Agora não escuta mais, não sei o que foi, né? Mas a gente escutava bater igual tambor nosso, batia dentro da água. A gente também passava a noite e ela saía da pedra. Enquanto tava passando a noite ela tá sempre passando por cima da cabeça da gente brilhando. Um monte de vez eu já vi e agora, há pouco tempo, outra vez. E qualquer um dá pra ver, estando descuidado dá pra ver. É uma coisa que a gente respeita muito o lugar.

Outro símbolo religioso da comunidade é a capela consagrada a São José Operário, que teve sua construção a partir da reivindicação dos moradores, devotos de São José e de São Benedito (ibid. p. 4). A partir da publicação Terras de Quilombos, temos uma exposição a respeito da relação da comunidade, suas práticas e o catolicismo local:

De acordo com Dona Terezinha, as missas antigamente eram realizadas na fazenda, e o uso de tambores gerava polêmica com os padres, sendo proibido por alguns deles. Em Santa Isabel do Rio Preto, aonde iam assistir às missas, os quilombolas também 
eram mal recebidos pelos párocos justamente por causa de seus tambores, que diziam ser "coisa de macumba", conforme Dona Terezinha. Felizmente, porém, nos anos 1990, chegou à comunidade padre Medoro, que não apenas admirava o batuque dos quilombolas como os incentivava a levar seus tambores para a igreja. Desde então, missa em São José da Serra não é missa sem a presença dos instrumentos (ibid., p. 4).

A presença do padre Medoro no território religioso valenciano é um marco apontado não só por Silva (2016), como também por Lucinda (2013, p. 241). O padre, que também foi pároco da Catedral matriz da cidade, tornou-se reconhecido pela defesa do diálogo inter-religioso. A partir dos relatos de Dona Tetê, destacados por Silva (2016, p.5), o padre realizou em maio de 1995 uma missa na igreja de Santa Isabel do Rio Preto com a participação dos moradores da comunidade. $\mathrm{Na}$ ocasião, pela primeira vez o toque dos tambores pôde compor livremente o rito.

Considerar as coletividades negras é, portanto, identificar mecanismos nãoocidentais de permanência e continuidade pela manutenção de vida e da memória. No caso em questão, tal mecanismo se sustenta em suas práticas religiosas e culturais pela oralidade. Como expõe o texto de Nelson Olokofá Inocêncio para o projeto A cor da Cultura:
A tradição oral está presente nos espaços de interação da população negra de modo a revigorar o espírito, alimentar a identidade e fortalecer o pertencimento. Por tais motivos, as narrativas tendem a trabalhar o contato entre gerações, considerando que o passado pode efetivamente explicar o presente e contribuir para reflexões sobre o futuro. Essa dimensão é da máxima relevância para que as coletividades não rompam seus elos (Inocêncio, 2006, p. 56).

A oralidade se expressa em diversas manifestações no Quilombo São José. No jongo, nas manifestações do terreiro, nas rezas e benzimentos, nas cantigas, histórias e conhecimentos para curas pelas ervas. Tais práticas fazem parte do cotidiano que circula entre os quilombolas, promovendo trocas culturais, educando e transmitindo seus valores. Esses rituais rememoram narrativas vividas marcadas pela luta, pela resistência, pela afirmação e permanência de valores. Traz a importância de destacar contornos históricos, bem como os eixos civilizatórios, refaz e transmite os laços com aquilo que foi vivido. Tais práticas e manifestações são instrumentos de afirmação de identidade e de reivindicação de direitos.

A oralidade é reconhecida por Azoilda Loretto da Trindade como um dos valores civilizatórios afro-brasileiros. A partir do projeto A cor da Cultura, 
Trindade investigou e expôs princípios que integram a educação, mas que, ao serem observados pela lente moderna, tendem a ser menosprezados e diminuídos, mesmo imprescindíveis para uma visão ampla de nossa sociedade. Seu trabalho contribui para esta pesquisa com a proposição dos valores afro-civilizatórios que auxiliam a refletir e expor as práticas herdadas africanas. Como bem pontua a autora, "não há um bloco homogêneo que possa ser classificado como africano/afro-brasileiro. Contudo, alguns aspectos podem ser constatados, porque os observamos em nós e nos outros e porque os sentimos" (Trindade, 2006, p. 97).

Tais valores de referencialidade afro-brasileiras são afirmados às ordens da circularidade (o círculo, a roda) (idem), da oralidade (a palavra dita, que carrega uma grande e poderosa carga afetiva) (ibid., p. 98), da energia vital (axé), da corporeidade (o corpo que se afirma e é vida, no aqui e agora), da musicalidade (idem), da ludicidade (a favor da vida), da cooperatividade/comunitarismo (a força no coletivo), da memória (que na História precisa ser descortinada), da religiosidade (tudo e todos os seres são sagrado, divinos) (ibid., p. 99) e da ancestralidade (que carrega o mistério da vida, o legado do saber-poder). A afetividade entra como um tema que percorre por todos esses princípios que se atravessam e se conjugam (ibid., p. 100).

Sobre a oralidade, encontramos essa definição no site do projeto:

Herança direta da cultura africana, a expressão oral é uma força comunicativa a ser potencializada. Jamais como negação da escrita, mas como afirmação de independência. A oralidade está associada ao corpo porque é através da voz, da memória e da música, por exemplo, que nos comunicamos e nos identificamos com o próximo. ${ }^{20}$

Discutir a tradição oral no quilombo São José envolve processos de subjetividade de um povo que, ao recontar sua história, mantém sua cultura e história vivas. Envolve também uma dinâmica de oralidade e tradição. A tradição oral, segundo Paul Zumthor (1997), é reconhecida como uma forma de cultura que presume um sistema de comunicação complexo com elementos que vão além da voz em si. Desta forma, o autor reconhece a oralidade poética presente na performance da tradição oral. As narrativas orais do quilombo se relacionam com a

\footnotetext{
${ }^{20}$ Extraído do site do projeto A cor da Cultura. Disponível em:

$<$ http://www.acordacultura.org.br/oprojeto $>$. Acesso em: 03 abr. 2021.
} 
música, a performance, a dança, ou seja, com o movimento plástico do corpo que narra sua história. Para Zumthor, a partir de seus estudos a respeito da poesia oral:

Performance implica competência. Além de um saber-fazer c de um saber-dizer, a performance manifesta um saber-ser no tempo c no espaço. $\mathrm{O}$ que quer que, por meios linguísticos, o texto dito ou cantado evoque, a performance lhe impõe um referente global que é da ordem do corpo (Zumthor, 1997, p. 157, grifos do autor).

Em uma dupla ação de emissão e recepção, a performance implica a presença e participação ativa dos agentes. Entre eles, há uma relação de permanência e construção conjunta de um mesmo saber. Ainda para o autor, a oralidade não se limita à voz e, embora seja uma expansão do corpo, não o esgota em sua ação. “A oralidade implica tudo o que, em nós, se endereça ao outro: seja um gesto mudo, um olhar" (ibid., p. 203).

A partir da reflexão de Zumthor, é possível estabelecer um paralelo das performances pela oralidade com o jongo, na participação ativa de seus agentes. $\mathrm{O}$ sistema de percepção de uma memória oral herdada de uma cultura africana, como Trindade nos expõe, expande os sentidos da performance para a compreensão do corpo. Se a tradição oral se mantém internamente, são os processos de subjetividade que a atualizam. Tais processos estão em constante interação e afirmação em comunidade.

É possível perceber como o conceito criado por Abdias Nascimento (1980) de quilombismo pode ser trazido para a reflexão. Segundo o autor, o termo, que leva o nome da obra, poderia assumir duas dimensões ligadas ao conjunto do complexo de organizações afro-brasileiras: a primeira enquanto importante instrumento de resistência de africanos e seus descendentes escravizados no período da escravidão; a segunda, enquanto conceito científico que o possibilita ser um instrumento de reflexão de permanência e afirmação de referenciais negros.

Genuínos focos de resistência física e cultural. Objetivamente, essa rede de associações, irmandades, confrarias, clubes, grêmios, terreiros, centros, tendas, afochés, escolas de samba, gafieiras foram e são os quilombos legalizados pela sociedade dominante; do outro lado da lei se erguem os quilombos revelados que conhecemos. Porém tanto os permitidos quanto os "ilegais" foram uma unidade, uma única afirmação humana, étnica e cultural, a um tempo integrando uma prática de libertação e assumindo o comando da própria história. A este complexo de significações, a esta praxis afrobrasileira, eu denomino de quilombismo (Nascimento, 1980, p. 255). 
O quilombismo se associa a forma de produção e manutenção da vida que parte de um diálogo de múltiplas experiências cotidianas nas comunidades. Fora dos parâmetros eurocêntricos, a reflexão trazida por esse conceito toma como ponto de partida a experiência de comunidade fora do continente africano, relacionando vivências e tradições assimiladas e herdadas aqui, como as relações com os povos originários.

Os sujeitos que não se encaixam às normas impostas, submetidos constantemente à marginalização principalmente por questões socio raciais, encontram nesses aquilombamentos, em referência à ferramenta teórica de Abdias, o espaço de articulação e interação necessária para dar outros contornos e leituras de vida.

A partir da década de 70, os pensamentos de Abdias e Beatriz Nascimento unem-se a esforços articulados ao movimento negro em recontar histórias dos quilombos sob outras perspectivas. Tal revisão possibilita recusar conceitos históricos estereotipados e resgatar noções de reparação, organização e estratégias para resistirem em seus costumes e liberdade.

Com as conquistas do simbolismo do dia 20 de novembro, Dia da Consciência Negra, o quilombo viria a se tornar um marco de resistência e auto-organização, local - em primeiro lugar geográfico - de recusa e fuga das formas externas de opressão, mas também espaço simbólico de resgate de africanidades e de manutenção de formas culturais que operam ao largo da cultura hegemônica. Nas palavras de Beatriz Nascimento:

\footnotetext{
Durante sua trajetória, o quilombo serve de símbolo que abrange conotações de resistência étnica e política. Como instituição guarda características singulares do seu modelo africano. Como prática política, apregoa ideais de emancipação de cunho liberal que, a qualquer momento de crise da nacionalidade brasileira, corrige distorções impostas pelos poderes dominantes. O fascínio de heroicidade de um povo regularmente apresentado como dócil e subserviente reforça o caráter hodierno da comunidade negra que se volta para uma atitude crítica frente às desigualdades sociais a que está submetida (ibid., p. 124).
}

Quilombo é então um sistema complexo, em que tentativas de delimitações territoriais não dão conta de justificar suas associações e forças. No caso deste estudo, partir de uma reflexão sobre o Quilombo São José Serra nos permite vislumbrar as sabedorias ancestrais atreladas ao território ancestral a que se habita. 
As culturas de subsistência e as relações sagradas com a natureza, práticas originárias e africanas de diversos povos passaram a ocupar o território religioso nomeado valenciano. É necessário destacar mais uma vez que não se trata de uma tradição específica, fugindo de tentativas totalizantes e violentas contra diversas etnias. A relação inseparável da natureza enquanto sagrado é a representação de muitas das cosmogonias localizadas no território valenciano. O sagrado está ligado às forças da natureza, as ervas trazem suas ativações e significados. Logo, seus usos possivelmente passaram a ser trocados e difundidos, principalmente em muitos locais estratégicos de resistência, como no Quilombo São José da Serra e em outros aquilombamentos.

Quando pensamos no caso valenciano, a reflexão de Abdias do Nascimento nos fornece inúmeros casos de quilombismo que mostram articulação e força política. A investigação de Maria da Consolação Lucinda, a respeito das irmandades e diversos terreiros em Valença, reafirmou a produção teórica, estética, política e cultural sobre a participação negra no espaço valenciano. A partir do estudo de Lucinda, é possível perceber a importância para a permanência de tradições pela oralidade, reafirmada como tecnologia e eixo civilizatório.

Diante das múltiplas ancestralidades que as agentes do benzimento acessam, esse estudo se aproxima de uma construção de narrativas que possam dissolver certos preconceitos acerca de diversas formas de vida presentes na região, reconhecendo e difundindo as sabedorias para fortalecimento da energia vital e enquanto princípio político cosmológico:

As benzedeiras e os benzedeiros quilombolas carregam consigo as marcas identitárias que os constituem em sujeitos da ação reivindicatória da luta por direitos e acesso às políticas públicas [...]. Teoricamente, as identidades culturais assumidas passam a responder pelas identidades construídas coletivamente e submetidas às condições específicas das trajetórias históricas de cada grupo, utilizando a memória e as experiências vividas pelas benzedeiras e benzedeiros nas comunidades (Mendes; Cavas, 2017, p.4).

Assim, traçamos a cultura do benzimento no procedimento afirmativo de valores culturais tanto no espaço quilombola quanto nas demais regiões do Vale do Paraíba Sul Fluminense. 


\title{
3 \\ Corpo que cura
}

Desde a infância, a ida até às benzedeiras para me livrar de males físicos, psíquicos e espirituais é algo que me acompanha e constitui. Esta longa convivência me proporcionou experienciar diferentes rezas e procedimentos de revitalização; em todos, sentia minha energia reavivada. Tia Rose, benzedeira com quem fui criado e participou do processo de pesquisa para este trabalho, mantém uma relação de troca de saberes com o posto de saúde próximo à sua casa. Seu saber oralizado e o conhecimento sobre as ervas são recorridos por médicos que reconhecem nela também uma autoridade de cura.

Um chá receitado por guardiãs de saberes tradicionais como tia Rose, para além das propriedades medicinais, contém uma força simbólica:

\begin{abstract}
Hoje, se um médico perceber, achar, sentir, que você precisa de uma reza, ele pode ter o CRM dele caçado. Isso me assustou profundamente. Mas o fato da medicina já estar olhando pra isso é uma prova de algo que muda. O postinho aqui perto de casa vai fazer um canteiro de ervas e me chamaram pra ajudar. Postinho aqui na esquina. Mas eles falam com muito receio, só com alguém que eles conhecem. Lá só tem médico de família, como chamam. Então, são três médicos e uma delas sabia que eu era chegada nessa área, então me chamou. E quando essa médica conhece a pessoa, ela já indica um chazinho como remédio. Ela já trata com outras alternativas ligadas a ervas. Nossa, aí é tudo de bom. A medicina não tem interesse porque não é rentável, né. Agora, comigo mesma, experiências de determinado mal que eu senti, quando cheguei no médico ele não sabia o que era, numa benzeção fiquei bem. Também teve situações que benzi e a pessoa ficou boa. As pessoas falam né, que se sentiram bem. (Conversa com Tia Rose em 16 nov. 2019)
\end{abstract}

Há nas rezas das benzedeiras a força de um gesto de cuidado, gestos conectados com a história singular de quem as conduz, assim como enraizados em suas tradições. São muitas sabedorias ativadas pela palavra; cada benzedor carrega consigo seu rezo, sua forma de curar. A atualização das rezas no ato das benzedeiras é uma ativação de suas tradições de cura de acordo com cada necessidade - com cada corpo tanto de quem reza como de quem se entrega ao processo de cura. A categoria de fidelidade ou deturpação de um cânone não cabe aqui. Há uma dupla contaminação entre indivíduo e coletividade que produz uma experiência particular e articula uma força em si e para o outro. Esta troca se apresenta como um saber 
ecológico (Santos, 2007), uma costura nos abismos, uma copresença radical pela diversidade epistemológica.

A língua é dinâmica. Nas rezas, nos cantos, no vocabulário ritualístico, pulsa um emaranhado de temporalidades heterogêneas. Quando o canto, a reza, é emitida com amor, fé, respeito e ética pelos fundamentos de suas práticas, a conexão com a força que se comunica é mantida e vitalizada.

É necessário destacar que as sabedorias tradicionais são, na maioria das vezes, produzidas de forma coletiva, sendo transmitidas e disseminadas oralmente. $\mathrm{O}$ saber de uma benzedeira passa pelo reconhecimento de sua eficiência por parte da comunidade em que vive. Trata-se de um "dom" articulado ao bem comum, construído a partir de uma experiência particular.

Azevedo (2018), com orientação de Lemos, em sua tese de doutoramento sobre a tessitura da cultura, religião e medicina popular com as benzedeiras, reflete que "notar a prática da cura como elemento de inserção e de fundação social, é vêla ao mesmo tempo como performatividade cultural também, de modo que as benzedeiras manipulam não apenas a doença e a sua possível cura, mas manipulam estruturas inteiras" (Azevedo; Lemos, 2018, p. 38). Entender a extensão daquilo que mobilizam requer investigar fenômenos como memória e seu modo de atualização que, como vimos acima, não segue regras prescritivas e rígidas, mas acolhe a singularidade dos agentes da reza. Diferente dos conhecimentos constituídos nos espaços acadêmico-científicos, estes outros saberes devem ser tratados de maneira adequada ao contexto em que são gerados, contando com o necessário reconhecimento de suas dignidades. É isto o que buscaremos elaborar a seguir.

\section{1.}

\section{Memória, arquivo e oralidade}

Palavra é encantamento. Quantas memórias resistem, insistem e reexistem a partir da tecnologia oral, vetor de conservação de muitas sabedorias. A imagem espontânea comum sobre a memória passa muitas vezes pela de um grande arquivo, como o das bibliotecas com seus acervos acumulados em infindáveis prateleiras, 
aguardando, empoeirados, até o momento da eventual consulta. Mas o que a noção de arquivo diz sobre o que trazemos como experiência de vida? No caso da fé, a atualização da memória faz com que se guiar no cuidado seja um ato revolucionário? Como produzir um arquivo sobre repertórios incorporados pela oralidade? Diante de questões que se multiplicam, utilizo como análise a investigação a partir de registros de experiências com agentes de cura e seus conhecimentos tradicionais na região que este estudo aborda. Tendo em vista um aspecto geral do arquivo, interessa-me discutir o caso específico das benzedeiras, com seus corpos que vibram mensagens transmitidas por gerações em prol da vida.

Assim como os arquivos físicos - de bibliotecas e outros espaços -, o arquivo encontra sua vocação enquanto se atualiza, não enquanto acumula poeira em virtude do esquecimento e falta de uso. Inseparável desta atualização é também a maneira como, ao fazê-lo, os arquivos produzem sentido. Como é afirmado em Indicionário do Contemporâneo a partir do pensamento de Foucault, "o arquivo é um território de disputa, pois controlar o arquivo significa controlar a possibilidade da enunciação e, em última instância, a construção de uma realidade" (Andrade; et al., 2018, p. 22).

A impossibilidade foucaultiana do arquivo, como comentam os autores do Indicionário do Contemporâneo, é justamente por ele não se apresentar como garantia da verdade absoluta, mas pela possibilidade de ser manejado como um dispositivo $^{21}$ que funcione no momento em que o ativamos. Para Foucault, a investigação se centraliza na relação do poder e do saber, entre aqueles que podem, porque dominam o saber, e aqueles que não podem. $\mathrm{O}$ arquivo então regula, produz as condições de enunciado, sendo este resultado de uma produção discursiva, levando-se em conta o contexto em que ocorreu.

A partir de uma leitura de Freud, o filósofo Derrida (2001) descreve o inconsciente como uma espécie de escrita e, desta forma, de arquivamento. De acordo com Derrida, a ideia de arquivo se liga ainda à ideia de destruição e à pulsão de morte freudiana. O filósofo aborda como a tendência à produção do arquivo é

\footnotetext{
${ }^{21}$ Segundo o Indicionário do Contemporâneo, o arquivo para Foucault se ativa enquanto dispositivo pois têm um valor em si mesmo, que persiste no tempo e permite ser atualizado. Como afirmam Pedrosa et al, "ele é o sistema, a louca lei, que nos permite achar espectros, elementos significantes, na poeira, naquilo que restou de uma experiência irrecuperável" (Andrade; et al. 2018,. p. 21).
} 
também a de seu apagamento. Essa tendência destrutiva é o que possibilita sua renovação, na produção do que é deixado registrado. É deste modo que podemos dizer que um arquivo, em sua imperfeição constituinte, guarda também a possibilidade de ser ao mesmo tempo revolucionário e conservador.

Todo arquivo existe então pela possibilidade de um novo relato sobre ele. Assim como todo usuário de um arquivo é um leitor, todo aprendizado, tido também pela observação, iniciação ou intuição, possui sua compreensão e, desta forma, de retomada. Modos de arquivar são modos de leitura.

Acompanhando a lógica do arquivo, cada benzedor guarda sua forma de rezar e enunciar palavras de cura. $\mathrm{O}$ modo como o arquivo combina múltiplas leituras da fé, produz uma força que potencializa quem o retoma. Há benzimentos entoados numa oração, cantados num ponto, transmitidos por gerações. Alguns seguem à risca o que lhes foi transmitido, outros elaboram uma construção única, autêntica.

Lembranças, biografias, sucessões, forças e rezas. O que se transmite é o poder ser ao máximo de si, o que o corpo gera em potência de fé na criação constante como forma de fornecer alinhamento e equilíbrio energético. Com as benzedeiras, os detalhes que constituem a particularidade do seu discurso tomam importância a partir do elemento intencional de incorporação na hora da reza. É como apresenta Nara, prima benzedeira que também participou de algumas conversas chave para elaboração desta pesquisa:

Eu tenho mania de estudar tudo. Quando eu comecei a estudar, eu comecei a quebrar os preconceitos e ver as filosofias das coisas, o cuidado com a natureza das tradições. Tudo relacionado à natureza. E aí via que a maldade era tudo preconceito. Tudo que me fortalece, eu tiro algo de bom. As pessoas vêm até mim porque estão sentindo coisas ruins, então tudo que há de bom pode ser útil. Eu sempre frequentei e sempre criei amizade com as benzedeiras em que ia. Uma vez minha filha torceu o pé e pedi pra vizinha me ensinar o benzimento de torção. Ela disse que poderia, mas ainda não era tempo. Então, acredito que tudo tem hora certa, tem seu tempo, principalmente ligado a espiritualidade (Conversa com Nara em 16 nov. 2019).

Parece-me necessário ainda ampliar a reflexão sobre o arquivo neste tempo de revisões, desconstruções e construções de outras narrativas. Nosso próprio tema já demanda esse esforço, ao buscarmos nos deslocar de uma ótica unicamente 
eurocêntrica. A pergunta que brota imediatamente é: que tradições ${ }^{22}$ precisam ser preservadas ou resgatadas, como joias ocultas de um tempo remoto? A segunda pergunta, que adiantamos antes do desenvolvimento da primeira, é: o formato arquivo, com sua evocação de uma biblioteca de documentos e livros acumulados, é a única imagem concebível para se pensar esta dinâmica de conservação de saberes e atualização?

O modo como tradicionalmente se canoniza a produção de conhecimento é um impedimento para o reconhecimento de narrativas ligadas à experiência de "narrar com", pelos modos de falar e construir uma reza, em que se encontram em jogo não apenas a tessitura de um texto, mas também sua ressonância no corpo. Se o corpo também fala e escreve - se inscreve - é, então, possível pensar uma política da oralidade no âmbito da escrita.

A escritora Leda Maria Martins cunhou o termo oralitura, neologismo que sublinha as qualidades literárias presentes nos ritos de ascendência africana. Em seu artigo A oralitura da memória (2000), Martins constrói seu argumento a partir da análise da performance dos Reinados, também conhecidos como Congados. A partir destes ritos, a autora aborda o lugar do corpo em performance ritual, que "restaura, expressa e, simultaneamente, produz esse conhecimento, grafado na memória do gesto. Performar, nesse sentido, significa repetir, transcriando, revisando" (Martins, 2000, p. 81). Sobre o termo, descreve:

A esses gestos, a essas inscrições e palimpsestos performáticos, grafados pela voz e pelo corpo, denominei "oralitura", matizando na noção deste termo a singular inscrição cultural que, como letra (littera), cliva a enunciação do sujeito e de sua coletividade, sublinhando ainda no termo seu valor de litura, rasura da linguagem,

\footnotetext{
${ }^{22} \mathrm{O}$ debate sobre a dialética das tradições é encontrado no artigo Inumeráveis cabeças - Tradições afro-brasileiras e horizontes da contemporaneidade, em que Edmilson de Almeida Pereira e Núbia Pereira de M. Gomes estabelecem dois segmentos: a tradição-nostálgica, "que - tal como a modernidade - permite ao sujeito construir um modelo daquilo que deve ser preservado ou do que precisa ser impulsionado pela mudança.[...] O substituto é ainda o antigo, porém, foi construído por este como uma imagem do novo (o possível)" (Pereira; Gomes, 2000, p. 52); e a tradição-princípio "partilha com a pós-modernidade a apreensão da mudança em termos de perspectivas, sem impor o retrato daquilo que seja apenas o passado ou presente" (idem). Segundo os autores, "uma sociedade como a brasileira tem criado campos que sugerem a pertinência da tradição-nostálgica e da tradiçãoprincípio, da modernidade e da pós-modernidade." (ibid., p. 57). "Pela análise que desenvolvemos, não há como classificar uma tradição (a nostálgica ou a princípio) como melhor ou pior. Os apelos contextuais e a responsabilidade dos sujeitos que as manipulam, no discurso cotidiano das comunidades ou no da militância política, é que delineiam a sua pertinência como fenômeno social" (ibid., p. 58).
} 
alteração significante, constitutiva da alteridade dos sujeitos, das culturas e de suas representações simbólicas (ibid., p. 83. grifos da autora).

No entanto, esse arquivo-memória não fala apenas de uma vida individual, mas também de uma família, de um grupo, de um povo. No caso da oralitura apresentada por Leda Maria Martins, é importante destacar que se conecta à concepção ancestral africana que "inclui, no mesmo circuito fenomenológico, as divindades, a natureza cósmica, a fauna, a flora, os elementos físicos, os mortos, os vivos e os que ainda vão nascer, concebidos como anelos de uma complementaridade necessária, em contínuo processo de transformação e de devir" (ibid., p.79).

Com esta definição, este estudo reflete sobre as práticas orais das benzedeiras abordadas. Se estamos tratando de sabedorias diversas, que reconhecem uma ética com suas ancestralidades, é preciso refletir a partir do compromisso epistemológico de outras visões de mundo.

Martins ainda apresenta, citando Drewal, os rituais, pois "cada repetição é em certa medida original, assim como, ao mesmo tempo, nunca é totalmente nova." (ibid., p. 81). Ela marca:

\begin{abstract}
Esse processo pendular entre a tradição e a sua transmissão institui um movimento curvilíneo, reativador e prospectivo que integra sincronicamente, na atualidade do ato performado, o presente do pretérito e do futuro. Como um logos em movimento do ancestral ao performer e deste ao ancestre e ao infans, cada performance ritual recria, restitui e revisa um círculo fenomenológico no qual pulsa, na mesma contemporaneidade, a ação de um pretérito contínuo, sincronizada em uma temporalidade presente que atrai para si o passado e o futuro e neles também se esparge, abolindo não o tempo, mas a sua concepção linear e consecutiva. Assim, a ideia de sucessividade temporal é obliterada pela reativação e atualização da ação, similar e diversa, já realizada tanto no antes quanto no depois do instante que a restitui, em evento (idem).
\end{abstract}

Com o entendimento da ativação de uma memória coletiva para manter a performance do ritual, Martins nos fornece ferramentas que auxiliam a refletir sobre as práticas de benzimento. Enquanto sucessão de práticas, Dona Fátima, benzedeira com quem também conversei no desenvolvimento desta pesquisa, enfatiza a necessidade de se voltar à espiritualidade como uma construção, um caminho percorrido que nos leva à força do que temos fé. Para a benzedeira, a confiança de seu trabalho como intercessora e guardiã da cura passa por reconhecer a força nos 
seus guias espirituais que atuam junto ao seu ofício. Ao manter ativas as práticas herdadas de sua bisavó, sua reza é reavivada no evento do benzimento:

Eu uso os ramos. Se eu achar um raminho verde, eu uso boldo e tem gente que fala tapete de Oxalá. Quando eu não rezo com boldo, rezo com guiné. Essas ervas aprendi com a minha bisavó. Ela trabalhava com o orixá Beira-Mar, a gente saia de casa até lá no centro cantando o ponto. E quando não tinham essas ervas, ela rezava com algum raminho verde. (Conversa com Dona Fátima em 16 nov. 2019)

Dona Fátima marca em seu depoimento a importância de ter adquirido com seus familiares os conhecimentos necessários para sua formação enquanto benzedeira, encontrando em sua bisavó referência naquilo que faz. A partir do que aprendeu, pôde iniciar seu desenvolvimento espiritual, ao qual se dedica e trabalha desde criança. Assim, o benzimento de Dona Fátima carrega também a força de Dona Albertina, sua bisavó, e de tantas outros tias e tios com quem se referência:

Todas as vezes que eu trabalho com a minha espiritualidade, eu penso sempre nos meus antepassados, nos meus avós, porque eles eram espíritas. Às vezes eu mesma me pergunto como aprendi, já que não tive professor. Mas eu tive professores que foram minha bisavó, meus tios. Um era crente, da igreja Deus é amor. Um era espírita, já faleceu, do centro Pai Mané. Tinha minha tia Alice, que era católica demais. Um outro tio era pagão, ateu, não acreditava em religião nenhuma. E minha bisavó - parteira e rezadeira. Era pretinha, pretinha. E sempre falava "em primeiro lugar é Deus, Jesus, Maria e José. Depois é você, você, você... pra você tá bem pra poder ajudar os outros". E eu também preciso ser rezada, preciso que rezem por mim. Eu não tenho mais minha avó, não tenho mais as pessoas que me faziam aprender e continuar aprendendo na parte espiritual. Um Pai Nosso, uma Ave Maria, você reza todo dia. Mas a prece que sai do coração, todo dia ela se modifica. As palavras se modificam, elas não são as mesmas todos os dias. Então, na hora que a gente está rezando, se você rezar pra você mesmo, vai sair umas palavras diferentes, mas aquela oração que sair do seu lábio é a que precisava sair pra você se encontrar como pessoa (Conversa com Dona Fatinha em 16 out. 2019).

A fala de Dona Fátima demonstra as forças que ativam seu repertório cultural na hora de fazer uma reza. É desta forma que tencionamos a reflexão acerca das práticas da oralidade e suas performances incorporadas no benzimento, possuidoras de modos próprios de produzir conhecimento que escapam aos parâmetros epistemológicos consagrados no eixo civilizatório ocidental. A noção de performance, ancorado nos estudos de Diana Taylor, reflete sobre "como a performance transmite memórias, faz reivindicações políticas e manifesta o senso de identidade de um grupo" (Taylor, 2013, p. 18). 
A não atenção aos modos de saber transmitidos pela oralidade, no que a autora denomina repertórios incorporados, revela, por exemplo, uma tradição que hierarquiza e apenas reconhece dignidade na escrita e na sua transmissão através da leitura.

Mais do que um parâmetro isolado e sem pressupostos filosóficos, podemos dizer a partir de Taylor que o conhecimento "arquivístico" se faz a partir de uma deslegitimação do corpo e em detrimento de uma celebração do espírito, pressuposto herdado da tradição da fílosofia grega e judaico-cristã. É por essa razão que a autora defende que reconhecer a legitimidade da performance requer uma nova ontologia: "Dizer que algo é uma performance significa fazer uma afirmação ontológica, embora localizada" (ibid., p. 27).

Segundo Taylor "a performance também funciona como uma epistemologia. A prática incorporada, juntamente com outras práticas culturais associadas a elas, oferece um modo de conhecer" (idem). Esta afirmação, no entanto, não termina nesse ponto. Para a autora, é importante ainda pensar a especificidade do tipo de conhecimento em jogo na ideia de performance, distintos daquele privilegiado pela cultura europeia, fixada por textos e pela escrita. Afirma a autora:

a fratura, a meu ver, não é entre palavra escrita e falada, mas entre o arquivo de materiais supostamente duradouros (isto é, textos, documentos, edifícios, ossos) e o repertório, visto como efêmero, de práticas/conhecimentos incorporados (isto é, língua falada, dança, esportes, ritual) (ibid., p. 48).

Não é à toa que liberar uma compreensão expandida de conhecimento abra igualmente a possibilidade de se reconhecer modos de existência abafados em nossa sociedade. Na tradição do racionalismo moderno, a violência física muitas vezes se fundamentou a partir da defesa de termos como "civilização" e "humanidade", algo que vimos no capítulo anterior a partir das palavras do Padre Aguiar. Suas formulações teóricas e, ao menos na pretensão, imparcialmente racionalistas sobre como construir uma nação embutem preconceitos e violências.

As reflexões de Martins e de Taylor tocam de perto em pensadores que buscaram reconhecer e desconstruir a violência da metafísica ocidental, especialmente Foucault e Derrida, filósofos que também refletiram sobre a primazia da escrita e o valor do arquivo no Ocidente. Estas perspectivas de construção do saber são de diversas ordens e referencias, passam por ativações que reconhecem a 
dignidade do corpo e não só um intelecto privilegiado somente à racionalidade. A partir da proposta de Taylor, é possível reconhecer e investigar práticas ensaiadas e performadas diariamente na esfera pública:

De quem são as memórias, tradições e reivindicações à história que desaparecem se falta às práticas performáticas o poder de permanência para transmitir conhecimento vital? (ibid., p. 30)

$\mathrm{O}$ ato de benzer analisado neste trabalho é praticado a partir das memórias incorporadas e performatizadas no momento da reza, produzindo fé ancestral no aqui e agora. Repertório é uma palavra definida etimologicamente por Diana Taylor como "uma tesouraria, um inventário" (ibid., p. 48). A possibilidade de acesso sob muitas benzedeiras, agentes da cura e herdeiras de diversas tradições de diversos povos, reflete sobre as performances de cura e energização vital que proporcionam.

O material incorporado que acompanha as benzedeiras traz consigo sabedorias ancestrais, ritos cultivados por gerações, mas também guardando suas particularidades, um modo de fazer singular, uma ética que respeita a espiritualidade, atualizada no momento da reza. $\mathrm{O}$ repertório requer presença “pessoas participam da produção e reprodução do conhecimento ao estar lá, sendo parte da transmissão" (Taylor, 2018., p. 50).

Este estudo então se questiona sobre uma conexão da ideia de repertório de Taylor a partir do termo oralitura de Martins. Segundo Martins:

O termo oralitura, da forma como o apresento, não nos remete univocamente ao repertório de formas e procedimentos culturais da tradição linguística, mas especificamente ao que em sua performance indica a presença de um traço cultural estilístico, mnemônico, significante e constitutivo, inscrito na grafia do corpo em movimento e na vocalidade. Como um estilete, esse traço inscreve saberes, valores, conceitos, visões de mundo e estilos. Se a oratura nos remete a um corpus verbal, indiretamente evocando a sua transmissão, a oralitura é do âmbito da performance, sua âncora; uma grafia, uma linguagem, seja ela desenhada na letra performática da palavra ou nos volejos do corpo (Martins, 2000, p. 84).

A partir dos conceitos de oralitura de Martins e repertório de Taylor entendemos que certas formas de escrita acionam o corpo como possibilidade de registro. Outros conhecimentos, escritos fora da lógica da tradição da escrita ocidental, utilizam a cultura expressiva (ritos, danças e celebrações) como transmissão e comunicação na interação social comunitária. 
Para o pensamento ocidental, a escrita torna-se avalista da própria existência, e com as ferramentas teóricas de Martins e Taylor, buscamos os rastros, o que revelam as frestas. Buscar outras formas de ser e de estar no mundo a partir das perspectivas de entendimento que marcam vivências guardadas e repassadas através de seus conhecimentos incorporados. Muitas dessas sabedorias prezam pela vivência com a natureza dentro das premissas de suas tradições - ser uma partilha com, mantendo a si, os seus, o ambiente em que se habita, as forças e humanidades que as potencializam.

Reconhecendo as múltiplas referências deixadas e plantadas por antepassados, as palavras de Makota Valdina, do Terreiro Nzo Onimboyá, trazem para este estudo um relato sobre como o ambiente, a relação de desenvolvimento junto com a natureza e em comunidade caminham juntos, sendo reafirmados no cotidiano:

\begin{abstract}
E a gente aprendia, né? A planta nascia espontaneamente e era aquela planta que fazia xarope, como Cambará, o xarope da raiz do Cambará, os chás que se faziam. Quando tinha dor de barriga, dor de cabeça, quando tinha gripe, ninguém ia pra farmácia, ia pro mato. Quer dizer, o mato era a farmácia da gente. As rezadeiras, benzedeiras, às vezes falavam "Ih, tá com olho quebrado, precisa rezar de quebrante, mau olhado". E aí, lá ia a pessoa pra frente da casa que tinha uma planta, ou no próprio quintal, ia lá e tirava pra rezar, benzer a gente. Que era uma forma de remédio, que mais tarde eu vim encontrar no candomblé, você se curar com as folhas, o banho de folhas, o chá que se toma. Então, o ambiente natural foi muito forte na minha infância. E a gente aprendia, como um aprendizado que ainda é dos terreiros tradicionais. Não tem livro, não tem apostila, mas é a vivência que te ensina. É viver com os outros. Naquela época era isso. A gente aprendia o que via com a mãe, a avó e a tia faziam. E tínhamos muitas tias, muitas avós, sem ser tias e sem ser avós. Mas eram mais velhas, era vovô fulano, minha avó, meu tio. Até um primo, uma prima, que já era de uma idade mais avançada, é o costume na minha família até hoje, são chamados de tios, os mais velhos (Valdina, 2018).
\end{abstract}

Apesar de a fala de Makota Valdina, extraída do documentário Retrato da Mestra Makota Valdina ${ }^{23}$ (2018), se referir à sua vivência na comunidade de Engenho Velho da Federação em Salvador, ela marca uma série de valores civilizatórios afro-brasileiros (Trindade, 2006) implementados e instituídos, que têm como registro de memória o corpo, seja o corpo individual, que carrega registros das vivências atuais e de gerações; seja coletivo, que fornece sentido à noção de identidade.

\footnotetext{
${ }^{23}$ Link de acesso: $<$ https://www.youtube.com/watch?v=FAc4CJr4qtM $>$. Acesso em 07 mar. 2021.
} 
O pensamento da reza pode trazer uma perspectiva outra ao observar o conjunto de organização e controle de seu arquivo e a consciência de seu repertório em contato com o mundo. A construção do seu arquivo é o que permite trazer a oralidade na bagagem do que se traz como algo valioso e preciso. A memória é um bem e seu artefato é o templo no corpo. A verdade é produzida não como absoluta, mas particular, uma construção no discurso e na vida em movimento. A verdade em construção de discurso.

Os arquivos da contemporaneidade pensam os textos, as leituras, as frestas, as nuances e as sobrevivências. As benzedeiras trazem o paradoxo, a complexidade de um sistema de arquivamento na incorporação de suas sabedorias que, ao mesmo tempo, carregam a tradição e crença nas forças que mantêm a transformação no ato da reza. O corpo no benzimento guarda a memória do que fomos para a construção do que seremos.

Nesse sentido, as benzedeiras são arquivos vivos no duplo sentido de Derrida: origem e comando. Pela oralidade, se ligam a um tempo imemorial de "início do relato" que atravessa gerações, criando sentido de mundo e de vida. Nas escolhas do cotidiano, na relação que estabelecem com o meio e a comunidade em que estão inseridas.

Em suas leituras do mundo e do outro, as benzedeiras narram o que dá origem, sentido e encantamento em suas práticas: o tempo, o lugar, as circunstâncias da iniciação de ambos e suas particularidades gestuais. Provérbios podem ser entoados, cantos podem ser proferidos e os mitos dão origem às dores e levam a cura para as enfermidades. A performance de bendizer é, antes de mais nada, uma prática de curar a si mesmo e encantar o mundo. Caminhando entre os mundos, os praticantes das rezas do benzimento detêm saberes das raízes, das ervas, das iniciações e da gestão da vida.

Minha escrita se coloca a partir da ideia de que o que escrevo me escapa como um conjunto de impressões que me tangenciam para a produção de sentido, entendendo que seu significado é ativado por muitas perspectivas. Esta é uma tentativa de arquivamento sobre algo que só deve ser experienciado no momento da intenção do bem dizer. 
Como ferramenta analítica, utilizo o repertório incorporado de meu arquivo, trazendo relatos documentados, ouvidos, vistos, sentidos e entoados, reconhecendo a faculdade da escrita como produtor de corpo. Vivências e experiências com benzedeiras que fazem parte da minha vida e com as quais pude desenvolver impressões para os fins deste trabalho.

Que narrativa faz um corpo? Que corpo é narrador? E benzedor?

\section{2. Encantamentos e benzimentos}

Esta dissertação trabalhou até aqui construindo o cenário local das benzedeiras de Valença e as tensões religiosas atreladas a mitos de fundação oficiais das cidades da região, tendo como foco os conhecimentos mantidos por tradições resistentes, conservadas e transmitidas no aporte de memórias e vivências comunitárias. Dentro da comunidade quilombola, é possível perceber as relações com o benzimento e seu território religioso. $\mathrm{O}$ ato de benzer, como mostrado e amplamente reconhecido na cultura local, possui raízes conforme as sabedorias de seus atuantes.

A força no cuidado se dá no aporte da fé ancestral. O benzimento se torna um território de reivindicação de práticas de cura que revelam concepções do sagrado, resistes através de seus fundamentos religiosos.

Esta análise permite ainda refletir sobre os processos culturais que envolvem as atividades das benzedeiras. Por se tratar de práticas que revelam valores e religiosidades de diversas culturas, a pesquisa sobre benzimento de Azevedo e Lemos revela:

Nessa mesma menção, a figura das benzedeiras continua a obter respaldo nos processos culturais de assimilação - processo pelo qual pessoas ou grupos de pessoas adquirem características culturais de outros grupos sociais -, difusão - processo pelo qual duas ou mais culturas diferentes, entrando em contato contínuo, originam mudanças importantes em uma delas ou em ambas -, enculturação - influência mútua entre o cristianismo e as culturas dos países em que a fé cristã é praticada -, aculturação - processo de modificação cultural de indivíduo, grupo ou povo que se adapta a outra cultura ou dela retira traços significativos -, endoculturação - processo permanente de aprendizagem de uma cultura que se inicia com assimilação de 
valores e experiências a partir do nascimento de um indivíduo e que se completa com a morte (Marconi; Presotto apud Azevedo; Lemos, 2018, p. 52).

Segundo os autores, os processos culturais envolvem as representações simbólicas e, no caso das benzedeiras, apresentam como as sabedorias, seus valores e práticas se dão no âmbito de transformações sócio-históricas. Azevedo e Lemos, ao citarem Marconi e Presotto, destacam como "as benzedeiras são entes culturais que difundem sua cultura, assimilam novas práticas, penetram em culturas tanto arcaicas como novas, resguardam sua tradição e transitam livremente em sua própria cultura" (idem).

A partir da reflexão destes pesquisadores, é possível notar como o local habitado pelas benzedeiras é onde se notam muitas das interações desses símbolos, como o quintal, o canteiro de ervas, os oratórios e espaços de rezas em seu lar. As rezas remetem a uma tradição, uma construção passada de gerações, uma religiosidade percebida por elementos do cotidiano, representando assim um modo de produção de vida. Trazem elementos que permeiam a fé cristã, do catolicismo ao espiritismo, e podem se localizar em práticas de tradições de religiosidades de matrizes africanas e de povos originários, estando ou não em terreiros de umbanda e candomblé da região. Localizada em meios a processos híbridos e sincréticos, essa expressão de religiosidade resiste e reexiste na contemporaneidade. No resgate das tradições de ancestralidade, incorporam-se costumes, produzindo a fé no aqui/agora.

Como Lucinda (2016) apresenta em seu estudo, muitos terreiros valencianos acabam por ter segmentos sincretizados e adotam valores que se aproximam de uma visão mais evangelizada. Novamente, vale destacar que não se busca alcançar um purismo em torno das atividades religiosas da região, e sim perceber outras tradições que escapam de uma tradição única.

O mesmo princípio deve ser buscado ao se pensar a atividade das benzedeiras, como demonstram Azevedo e Lemos:

Como forma religiosa não oficial, não formal, ou seja, não totalmente ou canonicamente aceita pela Igreja católica, sem mencionar as denominações também cristãs advindas da Reforma Protestante, a benzeção é um fenômeno constitutivo da religiosidade popular no Brasil. (...) ela emerge de um contexto cultural e popular, tendo, então, a mesma raiz. Sendo assim, aquelas que se dedicaram à benzeção 
enfrentaram resistências não apenas culturais, mas religiosas, ao longo dos anos, para se inserir ou serem bem aceitas socialmente (Azevedo; Lemos, 2018, p. 62).

No entanto, é importante frisar: a sobrevivência destas tradições não ocorreu por uma alienação em relação ao que os autores entendem como cultura oficial. Mesmo no centro da cultura católica também puderam crescer meios de resistência. Tratar da questão do sincretismo, desta forma, torna-se inevitável.

Se falamos sobre diferentes tipos de religiosidade, como essas composições de forças se configuram? Para além dos debates sobre como uma organização dominante impacta negativamente as demais (neste caso, uma tradição eurocêntrica cristã que acaba por definir a perspectiva de outras tradições), é importante refletir a maneira como a resistência também se faz por aglutinação e absorção da cultura hegemônica. Como Azevedo aponta em sua tese, "A religiosidade popular não se separando da religião oficial, também suas práticas não se veem separadas das demais práticas cotidianas, como é o caso das benzedeiras, dado que é função religiosa, santificar o dia, salvar o dia, dar-lhe sentido" (Azevedo; Lemos, 2018, p. $71)$.

Ainda sobre o catolicismo popular, localizamos o locus de muitas benzedeiras onde Azevedo e Lemos, ao citar Oliveira, situam no conceito de romanização:

\begin{abstract}
Nem sempre as manifestações populares de catolicismo são aceitas pela religião oficial. Quando isso ocorre, chama-se romanização. 'A romanização aparece, pois, como um processo de repressão clerical do catolicismo do povo. Porém, este último nem por isso desapareceu [...]. Para a burguesia agrária, como para os bispos e clérigos, a luta contra o Catolicismo Popular apresentava-se como uma luta contra a ignorância, o fanatismo, as superstições, as crenças atrasadas, as práticas imorais. $\mathrm{O}$ combate aparecia, portanto, como uma missão educativa a ser desempenhada pelo aparelho religioso, para elevar o nível cultural e religioso das grandes massas populares' (Oliveira apud Azevedo; Lemos, 2018, p. 85).
\end{abstract}

No âmbito religioso brasileiro do catolicismo, essas definições romanizadas ou populares se configuram mais como questões do campo político e de relações de poder. Para Azevedo e Lemos, ao apresentarem a definição de Oliveira, a pluralidade religiosa contida no catolicismo popular provoca atrito com expressões oficiais ou formais da religião, ao implicar a aceitação de tais práticas não romanizadas, que ocorrem de acordo com o direito canônico e livros litúrgicos. Afirmam os autores: 
Não há uma forma de catolicismo popular, mas inúmeras manifestações, e surgem novas formas a cada dia. Além de representar a fé de um povo, é expressão de uma cultura popular que altera por completo as formas romanizadas de culto e festejo religioso, e assume formas religiosas tão diversas, como é o caso das benzedeiras, elemento religioso que sobreviveu ao processo de romanização no Brasil e mais, ainda sobrevive, mesmo diante de uma religião oficial católica (Azevedo; Lemos, 2018, p. 87).

A ideia de uma religiosidade popular nos leva a refletir por onde essa concepção atravessa. Ao traçar o que seria a representação "fé de um povo", se apresenta a longa discussão do que é considerado cultura popular. Neste caso, é preciso estar atento a rotas reducionistas que levem à concepção da fundição de tradições em uma única categoria e não reforçar certos mitos. Como apresentarmos no capítulo 1, são muitos os conflitos que giraram em torno da definição de um "senso comum", ao privilegiar as partes interessadas.

Para os autores, as benzedeiras "partem de uma cultura religiosa católica em sua essência" (idem). Sobre essa ideia essencial, entendemos que as disputas no campo religioso sobre religiosidades entendidas como não oficiais atestam o que Lucinda (2016) traz em seu estudo acerca do território religioso em tensão com a evangelização de certos cultos e terreiros. A partir da tese de Lucinda, é possível observar os processos de estatização ou branqueamento, não atingindo o universo das práticas individuais, mas em reflexão a discursos que se fazem presentes em torno dos debates do sincretismo religioso.

Os princípios de dominação que menosprezam, violentam e jogam para a subalternidade saberes reconhecidos como "do outro" são mais uma expressão da colonialidade de poder que cristaliza suas estruturas. É como explica o professor e babalorixá Sidnei Nogueira sobre a intolerância religiosa no Brasil:

As ações que dão corpo à intolerância religiosa no Brasil empreendem uma luta contra os saberes de uma ancestralidade negra que vive nos ritos, na fala, nos mitos, na corporalidade e nas artes de sua descendência. São tentativas organizadas e sistematizadas de extinguir uma estrutura mítico-africana milenar que fala sobre modos de ser, de resistir e de lutar. Quilombo epistemológico que se mantém vivo nas comunidades de terreiro, apesar dos esforços centenários de obliteração pela cristandade (Nogueira, 2020, p. 55).

Para Nogueira, os saberes que compõem os territórios do sagrado negro se apresentam como "locus enunciativos" que dão conta de propor uma inversão na violência colonial. Prossegue o autor: 
Assim, esses saberes emergem como ações decoloniais, resilientes e transgressivas (RUFINO, 2017), assentes e perspectivadas por valores éticos outros (ancestralidade), estranhos às lógicas do pensamento cristão ocidental. Portanto, o racismo religioso tem como alvo um sistema de valores cuja origem nega o poder normatizador de uma cultura eurocêntrica hegemônica cristã (Nogueira, 2020, p. 56).

Desta forma, antes de tentar trazer uma essência, esse estudo volta-se para as práticas aglutinadas, com enfoque nas experiências das benzedeiras da região valenciana. Apesar de terem suas vivências atravessadas na religião oficializada, muitas dessas guardiãs da cura são atuantes em CTTro $^{24}$, territórios plurais de resistência que operam em ações emancipatórias e revitalizadoras, trazendo em sua estrutura saberes ancestrais afro-brasileiros.

Proponho um diálogo conceitual entre Nogueira, Simas e Rufino. Ao trazer a ideia de uma ciência encantada das macumbas, os autores evocam noções de ancestralidade e encantamento para demonstrar as torções que tais sabedorias operam:

\begin{abstract}
A partir das noções de ancestralidade e de encantamento praticamos uma dobra nas limitações da razão intransigente cultuada pela normatividade ocidental. São a partir dessas duas noções que se enveredam grande parte dos saberes assentes no complexo epistemológico das macumbas. Dobrar a morte, lida nesse caso como assombro, carrego e desencantamento fundamentado no colonialismo, se faz necessário para praticarmos outros caminhos. Esta dobra política e epistemológica é crucial para um reposicionamento ético e estético das populações que historicamente foram vistas, a partir de rigores totalitários, como formas subalternas, não credíveis (Simas; Rufino, 2018, p. 11).
\end{abstract}

O Ntu, para povos bantus, é o princípio da existência de tudo, a partícula de tudo que existe e tudo o que nos é dado a conhecer à existência. Esse conceito, que também é entendido como o princípio do Axé para os iorubás, é a energia vital que constitui tudo, a integralidade do ser, o valor supremo. Ler a vida a partir do vitalismo é a compreensão de vida para essas tradições. Ser é força vital, somos partículas universais de seres naturais. O que pulsa nesses conhecimentos consiste no aumento de força vital, sendo a palavra um meio por onde carrega a força vital, ela é a força. Malomalo (2019), em sua investigação sobre o Ntu, expõe:

A filosofia africana ancestral revela que conectividade se explica a partir do princípio de participação cósmica ou solidariedade participativa. Tudo o que existe está em

\footnotetext{
${ }^{24}$ Em referência ao termo proposto pelo professor Sidnei Nogueira, como explicado na Introdução desta pesquisa.
} 
conexão e deve conviver harmoniosamente porque tem a origem comum. Povos africanos postulam na base do que existe uma Matéria, uma Energia. Os Egípcios falavam de uma Matéria-Não-Criada Inicial, o Noun. Os Bantu do Ntu, os iorubas de Axé, os bakongo de Kalunga. A física moderna confirmou essas intuições filosóficas dos povos africanos e defende que na base do Universo está a expansão da Matéria/Energia que deu origem ao big bang. Está comprovada igualmente a existência de multiplicidade de universos. Esse Ser que faz Tudo existir é tratado como Sagrado. Por isso, a espiritualidade é tida como o caminho para se aproximar do Grande Mistério que é a Vida-Ntu. O que não dispensa o exercício da racionalidade. Nessa lógica, espiritualidade e razão complementam-se (Malomalo, 2019, p. 85).

Assim, ao compreender algumas forças que agenciam esses princípios de ser e estar no mundo, entendemos que certos espaços de revitalização e manutenção de costumes que ativam o ser se deram a partir da conexão pelos fundamentos de suas éticas ancestrais - que também são espaços de resistência. O princípio das encruzilhadas é elemento-chave para se pensar as bases epistemológicas desses locais.

Ao recuperar o pensamento de Nogueira (2020) sobre uma filosofia que emerge de uma ética responsiva com a ancestralidade no sagrado negro, verificamos que ele nos fornece a reflexão a partir da ideia das encruzilhadas. Para Nogueira:

É na encruzilhada, como um lugar que dá origem a vários caminhos, e de uma lógica exuística, ou aceitação de tudo que há de mais humano na própria controvérsia do orixá Exu, que terreiros/práticas de terreiro/rito/mito e a própria ancestralidade como horizonte ético, potência inventiva, assumem a reconstrução dos seres, a partir dos cacos gerados pelo colonialismo (Nogueira, 2020, p. 171).

Por meio da lógica das encruzilhadas, da lógica exuística relativa ao orixá Exu, reconhecemos nas atividades do benzimento os diversos caminhos que se cortam e se cruzam: as potências criativas, ligadas às diversas práticas ancestrais, nas dimensões de quem abençoa e de quem é atendido na experiência do benzer.

A ancestralidade e o encantamento são noções pelas quais é possível o descarrego colonial. Para este estudo, os saberes dos benzimentos atuam também no "complexo epistemológico das macumbas". Como signo ambivalente, "as curas se dão por baforadas de fumaça pitadas nos cachimbos, por benzeduras com raminhos de arruda e rezas grifadas na semântica dos rosários" (Simas; Rufino, 2018, p. 13). 
Inspirado nos referenciais de Lucinda, esta pesquisa se volta para a atividade de benzedeiras que se aproximam de práticas ritualizadas na umbanda, tendo como empenho descrever e trazer as experiências adquiridas com elas como parâmetro. A autora de Territórios Religiosos: conexões entre o passado e o presente (2016) apresenta o ofício das benzedeiras nas atividades no campo simbólico-religioso dos praticantes dos terreiros de umbanda em Valença (Lucinda, 2016, p. 107).

No entanto, vale tensionar o sincretismo em seus limites. Apesar de as benzedeiras que contribuem para este estudo fazerem parte da umbanda - esta sendo fundada no sincretismo, de modo que ser umbanda é sincretismo - há Ilês Axés de candomblé em movimento na contramão da necessidade de se sincretizar. Há linhagens do candomblé atualmente reafirmando o não sincretismo ${ }^{25}$.

Ainda sobre as ferramentas que o estudo de Lucinda nos fornece, o conceito de território religioso surgiu a partir das discussões de Dianteill. Segundo Lucinda, apesar de a abordagem ter sido retirada do estudo do contexto social cubano, as aproximações com os aspectos da umbanda em Valença e as religiosidades afrocubanas se aproximam em condições históricas. Desta forma, "o conceito de território religioso foi útil, portanto, para a sistematização e a interpretação do material sobre este evento e com seu auxílio foi possível tratar a umbanda como uma modalidade religiosa relevante na dinâmica social valenciana" (ibid., p. 47). Afirma ainda a autora:

A quantidade de locais de culto é um indício da representatividade no campo religioso local e, no que diz respeito à umbanda, especificamente, sua variação se expressa através de modalidades nomeadas como Congo-angola, Omolokô, "Evangelizada" e a denominada umbanda "de raiz" (ibid., p. 80).

A antropóloga então utiliza as análises e reflexões a partir de Serra dentro do debate crítico do conceito de sincretismo, ao tratar a variação de ritos e crenças umbandistas. Ela argumenta:

Serra $(1995$, p. 192) salienta que o hagiológio católico e o pantheon dos orixás constituem arranjos míticos que encerram classificações de seres divinos. Poder-seia dizer, acompanhando a reflexão de Serra, que muitos estudos se fixaram nesses arranjos, focalizando correspondências e, no dizer de Serra, uma "espécie de

${ }^{25}$ Essa questão, como aponta Lucinda, "teve destaque no âmbito acadêmico brasileiro em decorrência da publicização do 'Manifesto de Ialorixás baianas contra o sincretismo', efetuada pela imprensa de Salvador, no início da década de 1980" (Lucinda, 2013, p. 80). 
taxonomia", mas não aquela que ele aponta como processo similar à simbologia totêmica. A perspectiva assumida no presente trabalho é a de submeter o fenômeno empírico a uma interpretação baseada nesta concepção de sincretismo evitando a tentação reducionista e também qualquer tipo de taxonomia (ibid., p. 82).

Mais à frente, a autora traz uma descrição das práticas sincretizadas nos terreiros de umbanda valencianos investigados para sua tese:

A despeito de concordar com autores como Concone, Negrão (1985) e Birman (1983) sobre a umbanda como um sistema religioso estruturalmente aberto, um conjunto heterodoxo de práticas, em linhas gerais, as experiências identificadas em Valença podem ser sintetizadas do seguinte modo: os terreiros cultuam entidades africanas, caboclos, santos do catolicismo popular e entidades vinculadas ao espiritismo kardecista. [...] A influência do espiritismo, mais do que do kardecismo, é preciso assinalar, é anterior à emergência da propalada codificação e das tentativas de centralização da religião, cuja importância não se pode ignorar, tendo em mente, contudo, que diz respeito sobretudo à sua organização e não à prática e à experiência dos agentes religiosos (ibid., p. 94).

Dentro de sua investigação, Lucinda, junto a Serra, aponta como a caridade, uma das virtudes teologais tida como um dos princípios fundamentais da umbanda, é "a melhor defesa do sujeito" (ibid., 96). Assim, recordamos no capítulo 1 a abordagem dada aos fazendeiros como os grandes feitores da caridade na cidade. Este estudo é um deslocamento de lentes, realçando e dignificando tal virtude sob outras perspectivas. Nas palavras de Fran Alavina, jornalista e pesquisador ligado à umbanda:

Nesta religiosidade nascida de dentro do mundo da cultura popular impera a tradição oral, não há livros de revelações oficiais, nem versículos que sirvam de base para relações de mando e obediência. Diferenças de interpretação de um ou outro aspecto desta fé não conduzem à expulsão, ao silêncio obsequioso, ou à formação de tribunais. Aqui não há códigos de direito canônico, pois a justiça não se identifica com o legalismo de regras que estabelecem a superioridade dos executores e a inferioridade dos punidos (Alavina, 2017). ${ }^{26}$

A afirmação de Fran Alavina explicita que, para tais práticas de fé, o corpo deve ser reconhecido como potência criadora de realidade. A fé se realiza no corpo de cada praticante, com tal importância que a obediência a livros-tábuas-de-leis e sistemas fixados de escrita se tornam supérfluos. Tampouco se configura, como em muitos sistemas religiosos, o corpo como lugar de impureza, que a prática religiosa

\footnotetext{
${ }^{26}$ Disponível em: $<\underline{\text { https://outraspalavras.net/descolonizacoes/110-anos-de-umbanda-religiao-dos- }}$ oprimidos/>. Acesso em: 10 fev. 2021.
} 
deve buscar transpor por acreditar na sujeira da corporeidade contraposta à pureza do espírito.

Segundo ainda Fran Alavina, ao se referir à experiência da fé, "nela, o corpo não é um lugar vazio, sua dignidade não é dada de fora. Sua dignidade reside nele mesmo, não em um outro cujo lugar é o sobrenatural, mas na sua naturalidade" (idem). O corpo é ocupado, não marcado e em pecado. Alavina sinaliza que "sua 'glória' e seu valor se mostram tal como o corpo é agora: em toda sua debilidade e fortaleza" (idem). Não um corpo inerte, mas aquele que responde aos sons, aos cantos.

As questões que cercam o debate sobre o sincretismo são muitas, e este estudo utiliza também a abordagem proposta por Simas, a de observar as manifestações que produzem um acréscimo de força vital em suas práticas. Para seguir daqui, reconhecendo limitações e armadilhas de debates que enviesam e justificam somente a aniquilação, peço licença e invoco a força dos caboclos.

É através desta noção que Simas e Rufino (2018) recorrem como "categoria chave de um reposicionamento histórico e da emergência de outras sabedorias" (Simas; Rufino, 2018, p. 98). Os autores classificam o caboclo como supravivente e antinomia da civilidade, relacionando-o com a noção de encantamento:

No canjira dos encantados todas as mais diferentes formas baixam sob a condição de caboclos. Essa horizontalidade se dá, pois parte-se da premissa de que tudo que está a circular no mundo está passível de encantamento. A noção de caboclo é o suporte que encarna as formas de vida potencializadas pelo encante. (...) $\mathrm{Na}$ canjira dos encantados todos podem baixar sob o estatuto ontológico do caboclo.

Nas macumbas, umbandas e candomblés se dão processos parecidos, porém esses contextos, devido a determinadas experiências políticas, como as de promoção de uma suposta identidade nacional e os investimentos em processos de africanização, tiveram a pluriversalidade e as potências do termo caboclo normatizadas. Assim, é bastante comum, nos contextos citados, a reivindicação do termo caboclo limitada aos símbolos das pertenças ameríndias (caboclos de penas) ou dos marcadores identitários das populações dos sertões e campinas (caboclos boiadeiros). Porém, o que nos referenciamos e pretendemos lançar em debate é o deslocamento para o radical caboclo enquanto experiência de encantamento, existência e natureza dos seres. Assim, não tomando como princípio as apropriações e derivações do termo (ibid., p. 99).

O caboclo se apresenta então como a possibilidade de transformação pela experiência do encantamento. Um ser vivo pode estar aniquilado, logo, morto. 
Nesse sentido, a morte física não se relaciona necessariamente ao desencanto, mas "se abre como possibilidade de transformação, mais do que do morto, mas também e, sobretudo, dos vivos com quem o que aparentemente morreu interage" (ibid., p. 100). Esta é a noção, por exemplo, do trabalhador na umbanda, um "ente não vivo que aviva os vivos através do transe; visto aqui como viabilizador da plena interação entre os mundos aparentemente dicotômicos do visível e do invisível" (idem).

A umbanda é uma religião definida por Simas como:

um resultado do amálgama entre os ritos de ancestralidade dos bantos, calundus, pajelanças indígenas, catimbós (o culto fundamentado na bebida sagrada do tronco da jurema), encantarias, elementos do cristianismo popular ibérico e do espiritismo kardecista. Seus saberes moram na encruzilhada da cristianização dos ritos africanos e da africanização do cristianismo, com o tempero profundamente indígena. acrescentado aos poucos por diversas contribuições (Simas, 2020, p. 169).

É a partir também da figura do caboclo que a umbanda tem seu mito de origem. Ainda segundo Simas (ibid, p. 170), a versão mais popular do mito fundador narra que Zélio Fernandino de Moraes, na cidade de São Gonçalo, Rio de Janeiro, foi levado até uma rezadeira conhecida na região. Incorporada do pretovelho Tio Antônio, a rezadeira informou a mediunidade de Zélio e sua necessidade de desenvolvimento. No dia 15 de novembro de 1908, data comemorativa da Proclamação da República, Zélio foi levado à Federação Espírita de Niterói, onde, subvertendo as normas do culto, incorporou aquele que se apresentou como caboclo Sete Encruzilhadas. Como conta Simas:

Um membro da Federação inquiriu o espírito que Zélio recebia, com o argumento de que pretos velhos, índios e caboclos eram atrasados, não podendo ser espíritos de luz. Ainda perguntou o nome da entidade e ouviu a seguinte resposta: 'Se julgam atrasados o espírito de pretos e índios, saibam que amanhã darei início a um culto em que os pretos e índios poderão dar sua mensagem e, assim, cumprir a missão que o plano espiritual lhes confiou. E se querem saber meu nome, que seja este: caboclo das Sete Encruzilhadas, porque não haverá caminhos fechados para mim' (idem).

E assim nasceu o mito de origem da religião, mesmo que as práticas ancestrais já viessem sendo praticadas e experienciadas, como o caso da própria rezadeira que recebeu Zélio. Simas ainda conecta esse mito com a configuração excludente da sociedade brasileira:

A história da umbanda e os significados do seu mito fundador contam muito sobre os tensionamentos da formação brasileira. Há um país oficial que ainda tenta 
silenciar os índios, os caboclos, os pretos, os ciganos, os malandros, as pombagiras (mulheres donas do próprio corpo em encanto) e todos aqueles vistos como estranhos por um projeto colonial amansador de corpos, disciplinador de condutas e aniquilador de saberes. (ibid. p. 171).

Com esta macaia ${ }^{27}$, este estudo se tensiona e intersecciona as atividades de benzedeiras ligadas a heranças ancestrais e guiadas por entidades que as conduzem nas práticas da cura.

A força do benzimento ligada à figura ontológica dos caboclos pode ser percebida nas atividades de Dona Angelina. Registrado em vídeo por Chico Abelha, temos a possibilidade de conhecer a história desta benzedeira ${ }^{28}$.

"Eu tinha medo até de ir ao centro. Eu gostava muito da Igreja Católica, mas tinha medo de ir ao centro, os outros me verem e acharem que eu estava fazendo macumba pra eles, o meu medo era esse", afirma dona Angelina. Criada na fé católica, diz que o espiritismo já estava nela desde criança, quando via seu guia caboclo chegar. Ainda hoje, quando ele aparece em seus sonhos, se arrepia quando o vê. Nos sonhos, ele se ajoelha, reza e a leva para onde quiser ir. Segundo ela, ao entrar em alguma mata e ver uma árvore, já logo se lembra dele.

Nascida na zona rural de Ferreiros, Pernambuco, tomava conta de crianças quando ainda era nova, enquanto as mães iam cuidar da lavoura. Filha de carvoeiro, dona Angelina aos 14 anos chegou às terras do Vale do Paraíba do Sul para seguir "tomando conta de criança". A benzedeira de Vassouras, localizada a $34 \mathrm{~km} \mathrm{da}$ cidade de Valença, afirma que recebeu "a graça de Deus" para ser capaz de transmitir o ato de benzer. Ouvia vozes, as orações vinham em sua mente e ela passou a escutar explicações no pé do ouvido. A primeira vez que ouviu foi para saber como seu pai iria falecer. Todos os avisos que recebeu, acreditou com fé, livrando-se inclusive de cobras que apareciam em seu caminho ao adentrar em alguma mata.

Um dia ouviu que estava grávida e que sua filha viria nascer para "cumprir uma missão e depois iria voltar". Depois do falecimento da menina, pediu a Nossa Senhora Aparecida em oração para que deixasse de escutar as vozes que informavam o que poderia acontecer. Desde então, deixou de ouvir. Apesar disso,

\footnotetext{
${ }^{27}$ Macaia para algumas religiosidades de CTTro está relacionado às matas como morada de muitos "encantados" e se estabelece como fonte de muitos meios de cura.

${ }^{28}$ Link de acesso: $\leq$ https://youtu.be/IM7O9cMptoc_>. Acesso em 20 fev. 2021.
} 
dona Angelina seguiu firme com sua intuição. Sabe que é a partir dessas forças que elabora suas orações, que graças a elas obtêm proteção.

Dona Célia também reconhece na força de sua ancestralidade a capacidade de manter vivo o exercício do benzimento. Em outro registro audiovisual no canal do Youtube de Chico Abelha pela região sul fluminense do Vale do Paraíba ${ }^{29}$, conhecemos dona Célia e o Ilê Axé Afefé Oyá, também conhecido como Tenda Espírita Preta Velha Tia Genoveva, localizado em Barra do Piraí, a aproximadamente $30 \mathrm{~km}$ de distância de Valença. Dona Célia apresenta em sua fala a responsabilidade envolvida no ato do benzer e revela que a procura por seus serviços varia de acordo com a necessidade, sendo um recurso para diversos públicos. Dona Célia destaca seu compromisso com prática:

A minha mãe quando rezava usava um patuá. Patuá é o que o pai de santo faz com rezas, cruzos, rosário etc. Eu já rezava mesmo só com as ervas... Vassoura preta, folha de alecrim, depende do que a pessoa sente. Cobreiro a gente reza com folha de pimenta, pra secar. Um vento-virado, você já vai rezar com uma outra reza. As rezas são as mesmas que minha mãe ensinou e outras coisas que vem na mente, na intuição do que se tem a falar (Entrevista datada de maio 2014).

Há um fato, a partir da fala de dona Célia, que se evidencia no depoimento de muitas benzedeiras: a ética em seguir com as tradições herdadas por gerações e as práticas incorporadas a partir de suas intuições. No vídeo disponível no Youtube, dona Célia mostra o patuá de sua mãe, feito há mais de 70 anos, que só pôde ser utilizado para rezar depois de seu falecimento. Para o uso das ervas, dona Célia colhe às seis da manhã ou às seis da tarde - se for para algum rito do candomblé, recolhe entoando as cantigas que envolvem as práticas da religião; se for para umbanda, faz o pedido às forças que regem o ambiente, dependendo de onde se colhe e com qual finalidade aquela erva será utilizada. A indicação de chá de ervas ou banhos também pode ser feita dependendo do que sua intuição revela. Destaca que nesse caso a dosagem é muito importante, afinal, é uma prescrição.

Os registros dessas duas benzedeiras, dona Angelina e dona Célia, demonstram a força do benzimento que percorre pela região dado a um compromisso com suas ancestralidades e o desenvolvimento de suas

\footnotetext{
${ }^{29}$ Link de acesso: $<$ https: $/ /$ www.youtube.com/watch? $v=$ CCROND2QYaU $>$. Acesso em 20 fev. 2021.
} 
espiritualidades mediúnicas. No caso de dona Angelina, com suas práticas na comunidade em que vive, e com dona Célia, nas práticas que também se localizam no terreiro que integra.

As benzedeiras com as quais tenho contato e pude recorrer em conversas para anotações em meu diário de campo são constituintes de campos de atuação e referência do território religioso a que pertenço. Dona Fátima, Nara e tia Rose integram o campo do benzimento e são atuantes em seus terreiros de umbanda na cidade de Valença. Desta forma, a rede de sociabilidade a que pertencem se relaciona a suas atividades e compromissos espirituais, estendendo a ideia de trabalho e serviço à comunidade em suas casas. Assim, asseguram valores e fundamentos religiosos em suas CTTros e encaram a vida como pesquisadoras, indo em busca de conhecer e integrar em seus repertórios novos conhecimentos pela cura.

Nara e Dona Fátima mantém uma relação de compartilhamento de saberes, inseridas na mesma comunidade religiosa. Ambas são do mesmo terreiro, o Vovô Joaquim, localizado em Valença. Vizinhas, uma recorre a outra para trocar conhecimentos e quando precisam reavivar suas respectivas energias vitais. Em meu contato inicial, Nara, que é uma prima próxima, logo se disponibilizou a falar sobre suas práticas de benzimento, dado o reconhecimento que vem sendo cada vez mais alcançado por suas intervenções de cura. Mas, antes disse que seria importante conhecer sua amiga, que era "benzedeiras daquelas tradicionais".

Dona Fátima atende em sua casa, no bairro onde se encontra um dos hospitais particulares da região. Já logo no caminho do portão até sua casa os cheiros das ervas de seu jardim nos recebiam. Ao entrar no espaço, Nara, que nos levou até lá, vem anunciando a chegada. A cumplicidade das benzedeiras é marcada tão logo no primeiro contato. $\mathrm{Na}$ entrada da casa, um cachorro descansa. "É dos vizinhos, mas passa o dia inteiro aqui.” Dona Fátima demonstra sua arte de encantar os seres ao seu redor. Ela pede para que entremos, a porta já estava aberta, numa anunciação de abertura e confiança com o mundo. "Senta, meu filho".

"Fatinha", como também é conhecida, nos recebeu em sua sala. Quadros e símbolos nas paredes fazem o recorte de seu repertório de reza, como a de muitas 
benzedeiras que guardo na memória. Às 18h, nossa conversa se iniciou. Já logo no início, ela remete às bisavós, de quem herdou os ensinamentos do benzimento:

Quando eu comecei a rezar mesmo e falei "isso é o que eu quero" foi quando sonhei com a minha bisavó. Ela falava sempre pra mim, que quando a gente vai rezar alguma pessoa, primeiro a gente se reza. Elevar a intuição que você tem pra estar rezando. Eles é que te dão a intuição. Quem me incentivou muito mesmo a seguir minha crença, a umbanda, foi minha bisavó. Ela pegava na minha mão, me levava pro centro e íamos cantando o mesmo ponto juntas. Ficava sentada perto do banquinho dela, a única coisa que não aprendi foi tocar atabaque. Meu sonho era aprender a tocar. (Conversa com Dona Fátima em 16 out. 2019)

Dona Fátima enfatiza a necessidade de se voltar à espiritualidade como uma construção, um caminho percorrido que nos leva sempre ao mesmo lugar, com a força do que acreditamos. Para a benzedeira, a confiança de seu trabalho como intercessora e guardiã da cura passa por reconhecer a força dos guias espirituais que atuam junto a seu trabalho. Apesar de sua fala e relato mostrarem que se trata de um reconhecimento daquilo que seria um "dom" seu, ela enfatiza que todos podemos nos conectar a eles, "pelo menos para estarmos seguros". Dona Fátima rememora a sua criação religiosa e a oralitura incorporada de seu repertório:

Então, eu tinha minha bisavó - eu não conheci minhas avós, conheci minhas bisavós! E minha bisavó era parteira, a Dona Albertina, que era rezadeira. Eu com 6 anos, ela me pegava pela mão e ia pro centro dela para rezar. Ia com ela rezar porque minha mãe trabalhava. Então ela me ensinou tudo que eu sei, mas ela sempre me falava que eu já nasci com aquele dom. Por mais que você nasça com aquele dom, você tem que aprender. Porque a vida da gente é uma escola. A gente nasce pra aprender e morre sem saber. Quando você pensa que aprendeu tudo, você não aprendeu nada. Tenho 30 anos de santo e quero continuar a aprender. Hoje em dia eu tenho meu cantinho, mas ainda tô aprendendo. Porque como eu faço o bem pros outros, preciso que façam o bem pra mim, né - na espiritualidade. Não importa se você é crente, católico, protestante, umbandista, não importa a denominação de cada um de nós, o importante é sabermos respeitar o nosso entendimento. Às vezes eu fico me refazendo, vendo se estou fazendo certo. Não é porque eles me abandonam - os santos, os anjos, os orixás. É porque às vezes eu penso "Meu Deus, será que você está satisfeito com a minha crença, nessa religião?". Eu conheci uma porção delas. Agora não vou mais, a que me deu mais prazer de estar é a umbanda, rezar nela. O jeito que eu vou te rezar aqui não é do mesmo jeito que vou rezar outra pessoa. Porque o que sai aqui é o que sai do coração. É o mesmo desejo (idem).

Mesmo com um repertório de rezas a que recorre para cada circunstância específica, muitas surgem no ato do benzimento, produzindo novos enunciados de sua tradição. O corpo em harmonia diante da reza e da benção parte do acionamento e conexão com as forças espirituais: 
Às vezes eu nem sei rezar, eu deixo eles me conduzirem. Às vezes eu tô acreditando numa coisa e passa uma hora já não tô mais. Não é porque eu não quero: é a lei do ensinamento, do aprendizado. Você nasce pra aprender e morre sem saber. Você aprendeu, estudou na escola do homem, você aprendeu tudo, mas daqui a pouco você esqueceu. Na escola de Deus você nunca esquece. A gente tem a escola pra aprender as faltas, os defeitos não tem conserto. Só se quebrar um dedo e o médico colocar no lugar. Mas, o imperfeito não tem conserto - os erros têm. Eu quando vou fazer uma oração, eu faço de coração - não escrevo, não anoto, eu faço do coração. Porque cada pessoa tem um jeito de ser. Ela tem uma aura, ela tem uma energia. Então se você falar pra mim assim "Fátima, como é que você reza?", eu vou falar que rezo em nome do Pai, peço proteção a Maria e a José, vou pedir aos seus mentores, ver quem são os seus protetores. Eu sei que eles são seu anjo da guarda, sua mente, seu espírito e seu coração. Sem esses quatro, você não consegue fazer o que precisa fazer (idem).

Assim como dona Célia carrega junto com a tradição de seus ritos a consideração da força de sua intuição, dona Fátima demonstra também como o ato de rezar é vivo na hora de buscar a ativação necessária ao momento para a busca do benzimento. É seu repertório que enuncia as forças da cura, sua fé é o principal vetor de elaboração na hora de suas práticas:

Hoje em dia eu, Fátima, acho que a maior religião, a melhor oração é a que sai do coração. Porque você não vai tá decorando. Você lê uma Bíblia, foi aquela pessoa lá que escreveu, aquela outra, e aquela outra lá. Não foi uma pessoa só que escreveu. Foi um aprendizado de cada uma. Então se você fizer a oração que sai do seu coração, aquela oração é única, ninguém sabe (idem).

A fala de dona Fátima endossa a ideia da ativação de vitalidade pelo benzimento, na performance incorporada pela oralidade no momento de proporcionar a cura. Nas atividades dessas matriarcas, a preservação de valores ancestrais estabelece vínculos comunitários, mesmo que essa comunidade não esteja próxima fisicamente. Além das pessoas que mantém contato cotidianamente, Dona Fátima recebe telefonemas de pessoas que moram em outras regiões e costumam ser benzidas sempre que podem, ligam para agradecer e pedir novas orações. Já pela relação com Nara, ambas se curam, rezam uma a outra. "A gente que reza pros outros, precisamos que rezem por nós", afirmou dona Fátima. Mesmo que cada uma tenha sua forma de conduzir a cura pelo benzimento, o bem é sempre o mesmo, afirmam.

Ao encerrar nossa conversa, Dona Fátima colhe um ramo de boldo para aplicar seu benzimento. Nara, que acompanhou toda a conversa, nesse momento faz uma trança e segue atenta à experiência já vivenciada outras vezes. Dona Fátima não deixa de comentar "sua cabocla ajudou a fazer os trabalhos". Encerrada nossa 
conversa e experiência, nos despedimos de dona Fátima, e Nara me conduziu até a sua casa novamente.

A conversa continuou com Nara, a poucos passos de sua casa. Desde nova esteve ligada a práticas espirituais. Desenvolveu sua mediunidade, suas diretrizes e firmamentos em conexão com suas guias ciganas, a quem agradece e se volta a todo momento. Nara contou que o primeiro contato com a ancestralidade cigana foi quando havia se casado e vindo para o Rio de Janeiro, há muito tempo. Sem saber como preencher o tempo enquanto o marido trabalhava, ela saía pela cidade. Numa de suas andanças, se deparou com a imagem de um casal de ciganos. A partir desses ícones, inicialmente decorativos, Nara relata como essa representação passou a articular forças simbólicas, incorporando-se às suas atividades. Essa imagem é central em seu altar e dá o fio a suas práticas.

Sempre fui católica, minhas descobertas espirituais começaram há muitos anos, quando era casada. Um belo dia, passei por uma loja de artigos religiosos e vi um casal de ciganos que tenho até hoje. Fiquei deslumbrada, apaixonada. A primeira vez que vi só tinha dinheiro pro lanche. Passou um tempo. Um belo dia, passei de novo na loja e eles estavam lá, os mesmos. Aí falei, "são meus, eu vou levar, tão me esperando!". Há anos eles me acompanham, de início, como decoração. Tudo que era de cigano me chamava atenção. Aí fiquei muito doente, fui aos médicos e nada melhorava. Fui a um centro espírita e fiquei curada. Aí comecei a ir só pra rezar. Um dia por lá, meus guias se manifestaram. Daí em diante eu me joguei de cabeça. E fui vendo que tenho uma 'ciganada' comigo. Eu tenho fascínio, sou apaixonada. Meu benzimento vem disso, da minha mesa, do meu povo. Tenho um monte de livros que compro, comecei meus estudos. Não só de ler o evangelho espírita, mas também as práticas ligadas aos orixás. (Conversa com Nara em 16 out. 2019).

Para a benzedeira, sua conexão com a reza sempre esteve presente. Desde nova sentia-se sensível a esse cuidado. Conforme foi embarcando em seu desenvolvimento espiritual, passou a tomar conhecimento das forças que atuam consigo, um compromisso ético com a sua ancestralidade. Seus estudos pela leitura de livros fornecem uma ampliação dos conhecimentos que cada erva pode oferecer, mas também admite que muito do que sabe foi passado oralmente, adquirido pela observação com outras benzedeiras ou nos grupos de estudo de que participa. Reconhece as muitas forças de ativação energética pelas ervas, mas não tem uma específica que guarde em sua prática:

Pra rezar eu não tenho uma erva específica, pego a que tem. Mas os ramos são uma troca de energia, você pede licença pra colher, e você troca energia. Você passa energia pra planta e ela fornece a energia dela. Quando vou na casa de alguém 
benzer, vejo as ervas que tem no quintal da pessoa. Hortelã é uma ótima erva pra limpeza, se me oferecerem, eu pego. Até a sálvia, tem um poder magnético poderoso. A gente vai estudando sobre as ervas e vê que tudo é poderoso, tem que estudar pra saber. Sempre fui autodidata e muita coisa a gente intui (idem).

Sobre as relações que passou a articular, Nara destaca como o convívio com outras benzedeiras é fundamental para a afirmação de sua prática. $\mathrm{O}$ contato com o povo cigano se apresenta como igualmente necessário para absorção dos fundamentos e sabedorias que incorpora. Mesmo tendo sido criada sob outros dogmas e crenças, reconhece na força coletiva de sua atual religiosidade o compromisso que assume no benzimento:

Acabamos criando um grupo, é como a umbanda mostra, a gente vai se puxando por afinidades. E quando eu estou me sentindo pesada, eu também vou até elas pra rezar. De vez em quando vou lá. Se não se cuidar, a gente cai também. Tem ritual antes e depois do benzimento. Eu hoje participo também de encontros com comunidades e povos ciganos, aprendo muita coisa com eles. Essas trocas de conhecimentos acontecem, formas de proteção, dos procedimentos, como lavar os utensílios etc. Quando eu era adolescente, gostava muito de ver os ciganos nas ruas. Respeito muito (idem).

O benzimento articulado à ancestralidade cigana é também reconhecido pela bióloga e benzedeira Jacqueline Naylah. Em Eu te Benzo - O legado de minhas ancestrais (2019), Naylah descreve a tradição milenar guardada por povos ciganos, herdados de sua avó:

[...] guardiões dos mistérios, grandes observadores dos arquétipos humanos, peregrinos, aprendizes da vida, filhos do sol, da lua e das estrelas. Dentro de comunidades (clãs) aprenderam a viver e sobreviver com a simplicidade que tinham e suas próprias ferramentas do saber. Dessa forma, qualquer doença era sanada dentro do clã, em partilhas de saberes do que desvendavam nas descobertas dos benefícios das ervas, dos grãos, do fogo, da magia do sol e da lua, nas alquimias. Aprendiam também dentro de suas jornadas peregrinando por entre os povos do mundo, a cada canto, um saber. Parte do que hoje sabemos vem deles, parte deles foi o que levaram de nós (Naylah, 2019, p. 38).

A descrição de Naylah, embora localize a tradição cigana num período remoto, destaca o processo de lidar com as ferramentas do saber. A imagem da peregrinação entre diversos conhecimentos faz valer a fé que a sustenta como uma prescrição, como compromisso da benzedeira com a sua ética ancestral, que passa por uma identificação com as formas de aprendizado itinerante. Guardado seus 
fundamentos, é possível perceber como esta percepção embarca o modo como Nara incorpora conhecimentos em seu repertório de reza.

Essa forma de absorção de diversos conhecimentos para fortalecimento da fé ancestral é por onde tia Rose também se desenvolve. Tia Rose conta que sempre foi espírita, participou de muitos grupos de estudos espirituais e passou a desenvolver sua espiritualidade no terreiro de umbanda. Hoje ela compõe o corpo mediúnico da Tenda Espírita Caboclo Rompe Mato e Boiadeiro Menino. Reconhece as diferentes matrizes em suas práticas incorporadas.

O repertório de tia Rose guarda conhecimentos passados de mãe para filha, mas é cosido como uma manta de diferentes símbolos e procedimentos, incorporados ao longo de seus estudos espirituais e com a observação de outros rezadores. Dona Esmeralda, sua mãe, também benzia, mas sua primeira lembrança era de outra benzedeira:

Quando eu era bem pequenininha, lá em Rio das Flores, tinha uma senhorinha bem velhinha que rezava quando a pessoa torcia o pé, destroncava, era como a gente falava. De vez em quando a mãe me levava lá pra rezar as minhas peraltices. Dona Amélia rezava com uma agulha, chegávamos lá e pedíamos para ela 'coser'. Eu me lembro muito que ela falava coisas pra gente repetir, estávamos sendo 'cosidos'. Ela falava: 'Que coso? Carne quebrada', e dava um ponto no paninho com a agulha e linha. Linha branca, paninho branco. Aí ela falava e a gente repetia: 'Carne quebrada, nervo torto, osso rendido, junta desconjuntada'. E ela falava '...assim mesmo eu coso'. E rezava lá, fazendo 'cruzinha', com paninho com a agulha, em cima de onde a gente tinha machucado. E era sempre assim, alguma coisa que tivesse torcido, alguma coisa interna. Se caiu e ralou o joelho não tem reza, não. E foi o primeiro contato com o que eu chamo de benzimento. Eu não ouvia as coisas que ela falava, mas também não me interessava, não. Eu só queria repetir o que ela falava sem rir. Porque falar "junta desconjuntada" era muito pra mim. Aí eu segurava pra não rir, porque era uma velhinha muito brava, foi o primeiro contato que eu tive. O que mais eu guardo na memória do que a minha mãe falava é 'Leve tudo para as ondas do mar sagrado. Onde não se ouve galo cantar, nem pinto piar, nem boi berrar". Assim como a 'junta desconjuntada', isso ficou registrado (Conversa com tia Rose em 16 out. 2019).

A performance incorporada do benzimento de tia Rose reverbera o impacto do cuidado que recebia de outras guardiãs da cura. Dona Amélia, com seu benzimento, marca uma experiência fundadora de sentidos para a tia Rose. Também a observação de sua mãe e a troca com outras benzedeiras são experiências que compõem a força de sua oração. $\mathrm{Na}$ entoação da reza, acionam-se as práticas incorporadas em seu repertório: 
Um dia meu sobrinho destroncou o pé, a primeira coisa que ele falou foi pra coser ele. Aí eu peguei o paninho branco virgem, a agulha, a linha, fui lá. E aí eu lembrava que minha mãe falava de 'São Frutuoso'. Fazia lá o sinal da cruz no lugar quebrado, rezava Ave Maria e Pai nosso, pedia pra São Frutuoso ajudar, mas eu falava 'repete comigo: que coso' e aí era a Dona Amélia lá de Rio das Flores. E fazia três vezes, né, essa oração, e amanhã volto pra te rezar. Uma vez conversando com a Rosália (outra benzedeira), ela me falou de uma reza que alguém fazia, acho que o pai dela, que falava assim 'com que benzo, com água da fonte e raminho do monte'. Um belo dia, alguém me pediu pra rezar e o que eu fiz? Preciso de três raminhos de arruda, preciso de um copo d'água. E aí rezo a pessoa com o raminho, de arruda ou alecrim, fazendo sinal da cruz na pessoa, e aí vem, é, 'te benzo pela frente, pelas costas, em nome de Deus e da Virgem Maria, levando tudo para as ondas do mar sagrado, onde não se ouve galo cantar, nem pinto piar, nem boi berrar', porque era isso tudo que eu ouvia. Tendeu? (idem)

Assim como as benzedeiras citadas nesse estudo, a atuação de tia Rose, além de trazer a oralitura de outras agentes da cura que incorpora para sua prática, passa também pelo reconhecimento das forças ancestrais a que sua religiosidade se dedica.

Pra mim, o terço me remete a estar ligado a preto-velho e por ser de conta de lágrimas, porque esse terço o nome é "Lágrimas de Nossa Senhora". Isso pra mim, na hora do benzimento, tem peso, tem poder. Até porque eu misturo tudo, eu mando levar nas ondas do mar sagrado, eu falo Maria passa na frente, vai abrindo portas e portões no caminho dessa pessoa, entende? Faço essa mistura aí. Então, o terço tem um peso grande pra mim. Nas horas de aflição de alguém, já aconteceu de eu ter outro terço comigo. Que aí eu entrego a pessoa. É o terço da minha mãe. Então assim, acontece. Coisas assim que Deus nos envia. E a arruda ou o alecrim, o 'raminho do monte', pra mim é ligado a Ossanhe, por causa das ervas, então a água - que significa o elemento que te limpa, a pureza -, aliada a uma erva, vai conseguir limpar seu corpo melhor. São os símbolos que eu uso e o porquê que eu uso (idem).

Tia Rose reconhece que a força de seus benzimentos feitos com o terço são tanto por sua ligação à entidade dos pretos-velhos, quanto por serem feitos com os frutos da planta popularmente conhecida como Lágrimas de Nossa Senhora. Ao utilizar a ativação da oração pelas ervas, se conecta ao orixá das folhas sagradas e das ervas medicinais de práticas religiosas de CTTros.

Para Diana Taylor, em seus estudos sobre as performances latinas, muitas vezes diante de imperativos culturais que se colidem, atitudes tanto/quanto são valorizadas em vez de uma coisa ou outra. A partir do entendimento das forças tanto/quanto, como do simbolismo do terço para tia Rose, podemos associar a esta definição: 
Ir ao curandeiro ou espiritualista é outro exemplo da atitude tanto/quanto. Curandeiros, médiuns e espiritualistas consideram certos tipos de arquivos e repertórios culturais (ervas, pedras, cartas, signos cósmicos) como equivalentes à competência que exige conhecimento e entendimento, ao invés de crença (Taylor, 2013, p. 183). (grifos da autora)

O terço, forte símbolo religioso para muitas benzedeiras, traz o vínculo do catolicismo e, tanto para tia Rose como para dona Célia, remetem à força dos pretosvelhos. Os conselhos e as bênçãos dos pretos-velhos são fontes de vitalização e acolhimento para muitos. Como afirmam Simas e Rufino sobre a lição dessas entidades, "A astúcia de praticar a dobra na linguagem é a forma que temos de não nos subordinarmos diante da imposição de normas que nos violentam e nos negam enquanto possibilidade" (Simas, Rufino, 2018, p.73). Dessa forma, a sabedoria desses poetas feiticeiros das palavras é benéfica para a cura das mazelas. Afirmam os autores:

\begin{abstract}
O que os velhos nos ensinam é que existem inúmeras formas de luta. Em meio a um regime hierárquico e arrogante que os fixou como submissos e resignados, os velhos, através de suas sabedorias, inventam formas de praticar a dobra no sistema. O estereótipo produzido para abarcar as presenças negras como alegorias subalternas de um projeto de nação alicerçado nos parâmetros coloniais nos revela que o que ata os homens na banda de cá não é o contrato social, mas sim o racial. Fazendo barulho no silêncio os velhos armam suas arapucas no gungunado do palavrear, arriam no pé do cruzeiro suas demandas, alumbram o mundo como a fumaça pitada e fazem do verso flechas atiradas pela boca, fortalecendo a máxima: a palavra tem poder (ibid., p.74).
\end{abstract}

A educação e os ensinamentos transmitidos pelos pretos-velhos são associados por algumas tradições religiosas de CTTro ao saber jongueiro, transgressão na multiplicidade educacional e sabedorias que driblam e afirmam as potências da vida.

Para tia Rose, o que está disponível em seu repertório é possível de ser manipulado para levar a cura para a pessoa necessitada. A localização do que seria a romanização, citada em páginas anteriores desta dissertação, e o reconhecimento do catolicismo a essas práticas, é também elaborado por ela:

Se eu for benzer você e souber que você é de Oxóssi, eu vou pedir pra ele, mas também vou pedir pra Maria passar na frente, pra São Brás cuidar da sua garganta, e faço a mistureba porque tá tudo aí, não tem uma separação. Mas, a religião católica, ela nega um pouco de tudo isso. Não que os católicos não tenham essa prática. Até porque os católicos rezam pra uma pessoa. Eles podem não usar o raminho, embora alguns façam. O papa fala de ciganos e índios, alguns católicos não estão gostando, 
então vejo ele querendo resgatar alguma coisa aí, e isso pra mim é um indício. Essas possibilidades de melhora, com muito mais força (Conversa com tia Rose em 16 out. 2019).

Para a benzedeira, o cuidado e a ativação de seu benzimento confere uma interseção de forças pela proteção e devoção aos orixás, tanto quanto aos cuidados intercedidos pelos santos católicos. Como citado no tópico anterior, tia Rose, que mantém uma relação com o postinho de saúde próximo a sua casa, acredita que muitas dessas tradições que se associam, a ecologia de saberes que se estabelece para revelar e curar sintomas, são um resgate enquanto valor no cuidado, o amor ao próximo:

Eu acho que é a busca nesse resgate cultural pra saber o que vai interferir na vida da outra pessoa. Não é um resgate pra fazer uma exposição de arte, nada contra, mas não só pra encher um museu de coisa. Não. É resgate da cultura enquanto ser humano que pode ajudar o outro (idem).

A cultura do benzimento, carregada de suas heranças ancestrais das tradições religiosas que preserva, é o compromisso de se colocar para o outro de forma horizontalizada. Poderíamos aqui fazer um paralelo com a virtude da caridade, desta vez incitada não em um movimento social vertical de cima para baixo, como o que poderia ser associado à atuação dos "benfeitores" caridosos que mencionamos anteriormente, quando tratamos da fundação das cidades do Vale do Paraíba ligados ao ciclo do café. Tal virtude aqui pode ser associada à capacidade de, ao acessar as dores internas, ser capaz de promover a revitalização através do amor pela cura do próximo.

No ato de encantamento das palavras, sua força é reconhecida como deidade $^{30}$. Para algumas tradições africanas, como nos demonstra Amadou Hampaté Bâ (2010) em A tradição viva, ao traçar uma relação com a história tradicional, insere-nos no âmbito da oralidade, "nessa herança de conhecimentos de toda espécie, pacientemente transmitidos de boca a ouvido, de mestre a discípulo, ao longo dos séculos" (Bâ, 2010, p. 167):

\footnotetext{
${ }^{30}$ Nas palavras do professor e babalorixá Sidnei Nogueira, "deidade refere-se a um conjunto de forças e/ou intenções que se materializam nas/numa divindade(s). A deidade é a fonte de tudo aquilo que é divino. A deidade é característica e invariavelmente divina (criação), mas nem tudo que é divino é necessariamente deidade; ainda que esteja coordenado com a deidade e tenha a tendência de "ser/estar", em alguma fase, em unidade com a deidade - espiritual, mental e/ou pessoalmente" (Sidnei, 2020, p.145).
} 
O que se encontra por detrás do testemunho, portanto, é o próprio valor do homem que faz o testemunho, o valor da cadeia de transmissão da qual ele faz parte, a fidedignidade das memórias individual e coletiva e o valor atribuído à verdade em uma determinada sociedade. Em suma: a ligação entre o homem e a palavra (Bâ, 2010, p. 168).

O argumento do tradicionalista Hampaté Bâ é elaborado especificamente para investigar as heranças e memórias vivas da África, como uma das grandes escolas de iniciação do Mande (Mali), trazendo o valor do testemunho e da oralidade associados às muitas tradições africanas. Enquanto herança nas práticas enraizadas no território que esta dissertação aborda, identificamos como a dignidade do testemunho é um dos valores que permeia as práticas dessas guardiãs da cura. Por mais que cada benzedeira traga o seu próprio rezo, o compromisso com o que é dito reconhece o que suas palavras carregam: forças que revitalizam o ser.

Recorto o depoimento no livro-diário da benzedeira Naylah:

Ao longo desses anos de peregrinação conheci benzedeiras que entoavam mantras, que cantavam pontos de Umbanda, contavam itans (mitos africanos), cantigas, diálogos, orações cristãs, lamentos. Conheci uma benzedeira que em todos os atendimentos ela contava a história do nascimento de Jesus, tão lindo, tão único, tão dela (Naylah, 2019, p. 52).

Diante dessas diversas formas de ativar e encantar pela palavra, trazer as ancestralidades que atravessam a força do cuidado, reconheço o que Naylah diz ao afirmar suas descobertas: "Descobri que a arte de benzer é riquíssima, que cuidar do outro com amor e simplicidade é um patrimônio da humanidade, que todos nós podemos abençoar, com a fé no deus que habita em nós" (idem).

\section{3.}

\section{$O$ resgate de ancestralidades}

Até aqui, esta investigação esteve centrada na elaboração de uma compreensão das raízes do benzimento nas terras valencianas e na região do Vale do Paraíba Sul Fluminense. Como vimos, desde a sua fundação, os territórios religiosos valencianos revelaram diversas manifestações culturais, resistentes aos vetos impostos pela cultura dominante local, afetada pela colonialidade do poder 
vigente. Desta forma, seguimos daqui com a compreensão do benzimento como uma possibilidade de resgate de tradições de cura.

Como tratado no capítulo 1, Lemos revela como se deu o etnocídio no local dos povos originários conhecidos como Coroados. Mesmo diante da compulsória renúncia a hábitos e costumes tradicionais, a assimilação da cultura nativa não aconteceria com facilidade. "Foram levados à dispersão, na medida em que foram usurpados do seu espaço e colocados dentro de uma espacialidade incompatível com o seu modo de vida anterior" (Lemos, 2016, p. 201).

Para uma melhor compreensão deste quadro, podemos recorrer à reflexão de Taylor (2013), que propõe uma análise nos roteiros fixados pela performance do descobrimento, ativando lentes que muitas vezes ocultam ou deixam em segundo plano o desaparecimento de povos nativos. Um deslocamento na montagem deste roteiro (Taylor, 2013, p. 61) possibilita a reencenação de outras narrativas, revelam agenciamentos, áreas de resistência e tensão. Taylor tem um enfoque na colonização espanhola, mas que também serve para o caso brasileiro em virtude das similaridades no processo da colonização portuguesa:

O momento inaugural do colonialismo nas Américas introduz dois movimentos discursivos que contribuem para desvalorizar a performance nativa, mesmo enquanto os colonizadores estavam profundamente empenhados em seu próprio projeto performativo de criar uma "nova" Espanha a partir de uma imagem (idealizada) da "antiga": (1) a rejeição das tradições de performance indígenas como episteme; e, (2) a rejeição do "conteúdo" (crença religiosa) como sendo objetos maus ou idolatria. Esses discursos simultaneamente se contradizem e se sustentam um ao outro (ibid., p. 68).

Em afirmação de suas identidades, o movimento ressurgente de povos originários passa a estar presente no território valenciano. A partir do Movimento de Ressurgência Puri (MRP) ${ }^{31}$, dentre outros movimentos de povos originários na região, novos agentes e novas leituras passam a reivindicar seu espaço. Em conversa com o historiador Marcelo Sant'Ana Lemos, pude saber de uma

31 "O Movimento de Ressurgência Puri, segundo sua carta de princípios, se propõe a se organizar em rede, de forma descentralizada, através da liderança compartilhada, autogestão e respeitando a individualidade de cada membro, contribuindo para fortalecer núcleos Puris em diversas cidades e articular alguns deles, particularmente nas cidades de Araponga, Belo Horizonte, São Paulo, Rio de Janeiro, Maricá, São Fidélis, Valença, fortalecendo a atuação coletiva de Puris em âmbito local. Cada núcleo possui suas especificidades particulares, embora existam alguns aspectos culturais e demandas comuns" (Ramos, 2017, p. 142). 
benzedeira com tradições originárias em Rio Claro, também na região do Médio Paraíba Sul Fluminense, que reforça o reconhecimento da ancestralidade Puri nas matrizes do benzimento e suas contribuições como possibilidade de análise do campo político cultural religioso a que este estudo se refere.

A despeito de uma imagem nativos extintos, sempre vinculados a uma qualidade negativa, submetidos a um olhar estereotipado como "canibais e selvagens", é possível verificar, a partir da leitura do livro de Paulo Pereira dos Reis O Indígena do Vale do Paraíba, que a acusação de canibalismo dirigida tanto aos Puri como aos Coroados carecia de evidências (Reis, p. 70, 1979).

Ao contrário, Reis afirma, por exemplo, que "os Puris exerciam práticas curativas graças ao conhecimento de raízes e plantas medicinais, que aplicavam em caso de enfermidades" (ibid., p. 85). Este é um dos relatos que auxiliam a contribuir para um olhar longe da visão limitadora diante das sabedorias dos povos originários locais.

O trabalho de conclusão de curso de Opetahra Nhãmanrúri Puri Coroado, Solange de Souza Reis, contribui para compor o resgate de vivências Puris. Em Onde estavam os indígenas Puri quando o sistema os dava como extintos? Nós estamos aqui, vivos! Orando, rezando, curando, plantando, lutando, resistindo e ressurgindo (2020), seu trabalho de conclusão de curso em Educação do Campo pela Universidade Federal de Viçosa (Minas Gerais), a autora cita Freire e Malheiros "eles [os Puris] sabiam designar quase todos os animais, todas as árvores, todas as ervas do mato com o nome próprio e davam informações minuciosas sobre a utilidade de cada um" (apud. Reis, 2020, p.20). Os autores demonstram uma das práticas relatadas em memórias familiares de Opetahra:

Nós, muito raramente ficávamos doentes, pois sempre tínhamos conosco chá de ervas, xaropes e realizávamos a defumação da casa com plantas como alecrim, alfazema e erva doce. Tínhamos a capacidade de produzir todos os remédios a partir das ervas. Eram comuns os chás e os banhos. Algumas plantas bem comuns no nosso dia a dia: saião, boldo, cordão de frade, hortelã, erva doce, manjericão, alfazema, arnica, jurubeba, pinhão roxo, guiné (banho), arruda (banho), quebra pedra, cana do brejo, cabelo de milho, folha de laranja da terra, alho, cebolinha e mamona, dentre muitas outras possibilidades (Reis, 2020 p. 28).

A autora e uma das líderes do Movimento de Ressurgência Puri se questiona sobre os saberes de sua mãe e a memória dos Puris. "Em conversa com um Puri 
xamânico, ele me descreveu exatamente a forma da minha mãe curar doenças e eu comparo com a pajelança e fico intrigada. Será que eu tenho estes dons herdados pela minha mãe? Também uso as ervas medicinais e consigo excelentes resultados" (ibid., p. 33).

O trabalho de conclusão de curso de Opetahra faz um reconhecimento dessas sabedorias a partir do resgate de suas memórias. Ter um local para plantar e estar em contato com a terra é determinante para o desenvolvimento na cura de doenças. Mesmo diante de dificuldades, o ato de cuidar a partir dos conhecimentos das ervas encontradas no quintal, com a força de sua fé, atuam na força de vitalização e resistência dos saberes Puri.

A partir do acesso ao portal Centro de Memória do Povo Puri ${ }^{32}$ foi possível pesquisar a respeito deste povo originário, com material produzido a respeito de suas histórias, língua, cultura, território, medicina e tradições. Pelo acervo dos materiais em diferentes formatos, principalmente o audiovisual, podemos resgatar o depoimento de alguns Puris.

No vídeo Karaí Mirim e a cosmologia do ser, Vozes da ressurgência PuriEpisodio III - Cosmologia e o Ser (2019) ${ }^{33}$, Karaí Mirim mostra como a cosmologia Puri passa pela ideia do ser enquanto força cósmica. Karaí explicita que as tradições milenares vêm mantendo seus processos a partir da religiosidade. Diferente da ideia de religião, criada pela ação do homem, a religiosidade nasce com o ser humano enquanto ser espiritual. E os processos que envolvem a afirmação da religiosidade Puri é apresentada por Karaí Mirim no batismo:

O batismo é a consagração que vai manter em frequência a sustentação, a manutenção e a conexão enquanto ser espiritual, no ciclo do movimento de vida na terra, para seu aprendizado com a essência divina, com o grande espírito que é o cosmos, em todos os sentidos. [...] Então, o núcleo de resistência das tradições da nação Puri, ou povo originário Puri, é a religiosidade. E dessa religiosidade, nós temos a nossa conexão com o pai celestial, o grande espírito, no sentido da cosmologia. Na vivência das tradições Puri vem todo um estudo ritualístico. Esses rituais seguem um alinhamento dos ciclos lunares. Nesse conhecimento dos ciclos lunares, vem todo um conhecimento de frequência, sustentação e manutenção dos rituais. Dentre esses, tem o ritual do batismo que é muito importante, é muito interessante. $\mathrm{O}$ nome, generalizando todos os povos originários, faz o mesmo sentido. Quando a gente recebe um nome, seja ele em que povo originário for, esse

\footnotetext{
${ }^{32}$ Link de acesso: $<$ https://povopuri.wixsite.com/memoriapuri $>$. Acesso em 09 mar. 2021.

${ }^{33}$ Link de acesso: $<$ https://1drv.ms/v/s!AoZMkO1ExG2nc3h7rt5_DObD1sw $>$. Acesso em 09 mar. 2021.
} 
nome não é dado porque o nome é mais bonito, porque o pai e a mãe que escolheu, não. [...] Então, veio um nome Puri, o Puri recebeu o nome pelo sacerdote, o pajé, para que seja mais compreendido. O pajé também não deu o nome porque quis. No ritual, ele puxou na conexão do sagrado entre o povo como um todo, o coletivo, com o pai celestial. Pai celestial fica parecendo coisa de cristão né? "O europeu veio e trouxe...", não. O pai celestial, vamos traduzir, tem essa representatividade na língua? Tem. Puri Dokora, representação. Em Guarani, Nhanderu Tenonde. Nhanderu, nosso pai. Não tem nada a ver com europeu. A terminologia já existia, nem sonhava de o europeu chegar. Nhanderu Tenonde, nosso pai que está em todo lugar, todo cosmo. É a ação da lei em movimento. Então, a força, o pajé, dá o nome. Deu o nome? O Puri pode caminhar, caminhar, ir pra outro estado de seu território por ele ser nômade, um outro sacerdote lá da outra área, numa [outra] consagração, vai repetir o mesmo nome. O nome é o nome, é sagrado, ele vem, é o mesmo. Não são nomes diferentes (Mirim, 2019).

Partindo da cosmogonia e o batismo Puri, visualizamos como o movimento de ressurgência caminha atrelado ao reconhecimento de resistências, tratando-se de processos distintos. Pelo reencontro com suas ancestralidades, pessoas de uma mesma etnia tem se reconectado, ressurgindo enquanto retomada e resistindo com os conhecimentos que detêm. Parte dessa conquista se deu nas articulações da ocupação conhecida como Aldeia Maracanã, situada no antigo prédio do Museu do Índio que estava para ser derrubado. Ao lado do estádio do Maracanã, entre 2006 e 2013, esta ocupação multiétnica, articulada com vários povos originários, contou com algumas das principais lideranças indígenas tradicionais, para projetos de apoio na luta por direitos e pela preservação, valorização e difusão de culturas nativas do Brasil.

Em outro vídeo no portal do Centro de Memória do Povo Puri, conhecemos Carmel Puri, a Butan Puri. No vídeo Puky Na Thamati (Puri bem vivo) ${ }^{34}$, feito para exposição Dja Guata Porã | Rio de Janeiro indígena, ocorrida entre maio de 2017 e março de 2018 no Museu de Arte do Rio, Carmel conta como pela convivência com a avó pôde reconhecer em práticas como a do benzimento a identificação por tradições ancestrais de seu povo. Ela demonstra ainda a importância da Aldeia Maracanã:

E com essa minha avó é que eu fui entender o que era Puri. Essa minha avó rezava, a minha avó benzia, traziam muitas crianças para ela. Eu sei que quando eu conheci a aldeia Maracanã, que foi uma referência na minha vida em relação a encontrar com outros povos, é que eu fui encontrar a etnia Puri. Então eu me dei conta que eu era índia, mas a gente quase não falava a respeito disso, só na Aldeia Maracanã. Aí eu

\footnotetext{
${ }^{34}$ Link de acesso: $<$ https://1drv.ms/v/s!AoZMkO1ExG2ndhIRAqQZTUrNY1Y >. Acesso em 09
} mar. 2021. 
conheci o Dauá, e o Dauá lembrou muito um tio meu. Conheci um movimento, que também partiu dessas pessoas que ele me apresentou, que era o Movimento de Ressurgência Puri. A essência agora, a mensagem agora é ser forte, é ir em frente (Puri, 2017).

O poeta e contador de histórias Dauá Puri, na construção da tradição literária de seu povo, atribui aos poemas que cria às energias naturais do lugar onde escreveu. Em publicação bilíngue Puri (Macro-Jê) - Português, Dauá constrói narrativas que constroem a literatura tradicional de seu povo. No poema de título Tutu, associada às energias da cura, ele grafa:

Tutu brâ uchô

Tatu abre a terra

Uchô mehtlon tutu

A terra dá força a tatu

Krim tutu bokê tê immih

O sangue do tatu espirrar no corpo

a soua popeh tutu bokê tê immih

Cozinhar casca de tatu espirrar no corpo

$N^{\prime}$ dond cadando immih puki

Cura a doença do corpo puri

Mehtl'on kschê samee cocha

Força dentro da criança grita!

Ah tl'amatl'i

Eu gosto de tatu

(Puri, 2016, p. 8)

Muitos saberes Puri vêm sendo resgatados. Suas religiosidades e formas de cura são expressões relevantes do que compõem o repertório cultural para o seu ressurgimento. Novos trabalhos vêm sendo produzidos e contribuindo para o reconhecimento desta etnia sob outras óticas e garantindo a resistência e permanência desta tradição.

$\mathrm{Na}$ investigação dos saberes que o benzimento pode guardar, entendemos que muitas dessas práticas se mantiveram ativas, unindo forças em diferentes culturas que também visavam a sua resistência e existência. Já embarcamos nos debates sobre o sincretismo, mas agora nos voltamos para a força de construções comunitárias estratégicas e mantenedoras de tradições sagradas que impactaram em suas culturas.

Para o professor, compositor e estudioso das culturas africanas Nei Lopes, na série Mojubá do projeto $A$ Cor da Cultura $^{35}$, o contato dos povos bantos com os

\footnotetext{
${ }^{35}$ Link de acesso:

$<$ https://www.youtube.com/watch?v=mpjxTzsQfQk $>$. Acesso em 02 mar. 2021.
} 
povos originários que habitavam aqui estas terras, pelo fato de trabalharem na zona rural, proporcionou a troca de experiências no campo das plantas, no campo da medicina empírica e efetiva, a medicina tradicional dos vegetais e no campo religioso.

A partir também dos estudos de Beatriz Nascimento (1982) em seu estudo sobre o quilombo de Carmo da Mata, em Minas Gerais, é possível reconhecer as associações entre os povos originários e os povos cativos em diáspora.

Através dos depoimentos orais, viemos a saber que o quilombo de Carmo da Mata organizou-se a partir do contato dos negros "corumbas" com os índios puris, que habitavam aquela região. Os negros eram da nação bantu, de uma etnia m'bunda. Viviam de caça e de pequena lavoura de abacaxi, feijão, banana e extraíam, ainda, o palmito. (Nascimento, in: Ratts, 2006, p. 113).

O trabalho da historiadora aponta para a constituição diversa das organizações quilombolas, envolvendo indígenas, mestiços e outras pessoas dissidentes ao sistema escravocrata que marca o início do projeto colonial.

Já segundo Tata Carlos Kavungo, no documentário As Nações do Rio de Janeiro $(2003)^{36}$, a natureza integra os valores civilizatórios dos povos bantos que se estabeleceram nessas terras:

A cultura banto, a cultura Angola, ela é regida por fundamentos de folhas, inclusive chamada nação das folhas, as nações das rezas. Nada se faz na cultura Congo Angola, na cultura Angola, que não tenha reza. $O$ ato de tirar uma folha, o ato de cair uma folha no chão, $o$ ato de se pôr as mãos na cabeça do iniciado, o ato de louvar o Nkisi, o ato de louvar uma energia da natureza, tudo é regido por folhas. Às vezes, quando se louva a tradição da nação, a tradição que veio da África, se reza assim (reza entoada). Então, você vê, nessa reza nós louvamos a tradição e a ancestralidade da nação. Às vezes você tem que louvar uma folha, aquela folha que caiu no chão. [...] Tudo da Angola tem uma energia, que junta a terra ao céu, que junta os elementos. [...] São religiões que cultuam basicamente natureza e louvores às ancestralidades. São religiões de comunidade. As religiões de candomblé, elas querem juntar as famílias, juntar as comunidades. Desde África até aqui (Kavungo, 2003).

As falas de Nei Lopes e do Tata Carlos Kavungo descrevem a importância e a relação da natureza para os saberes bantos. Como as CTTro, a relação com o espaço sagrado é a possibilidade de resgate de tradições. Também por isto, o

\footnotetext{
${ }^{36}$ Documentário realizado como co-produção com o Curso de Cinema da UNESA - campus João Uchôa em 2003. Link de acesso: < https://www.youtube.com/watch?v=TEVdHjn9uZo >. Acesso em 02 mar. 2021.
} 
ambiente de um terreiro é sagrado, envolve uma reunião de pessoas para o avivamento de práticas e crenças em reconhecimento de múltiplas humanidades.

Como exposto no capítulo anterior, os espaços das CTTro podem ser reconhecidos como aquilombamentos. Historicamente, são territórios de resistência negra, e a depender de suas tradições se comungam resistências dos povos originários, que se configuram como espaços de cura e fortalecimento. As CTTro possuem suas bases epistemológicas a partir da manutenção das tradições que carregam junto a suas ancestralidades. Enquanto espaço ancestral afro-brasileiro, estão para suas comunidades como algo que está para além do atendimento a desejos individuais daqueles que os buscam, mas, antes de tudo, são ambientes de manutenção de suas forças na coletividade e firmamento.

Ainda assim, mesmo fora desses espaços de pertencimento, há resistências de saberes ligados aos valores sagrados do ambiente natural. No documentário Alquimista do Mato (1980), de Jom Tob Azulay, conhecemos o senhor José Thomaz dos Santos, conhecedor da medicina das ervas da cidade de Vassouras, que afirma:

\begin{abstract}
A vitamina da natureza é embutida da terra. A terra cria aquela planta e cada planta tem uma vitamina. Todas as plantas que se vê do mato, a gente não tem ciência do que ela cura, mas todas elas têm utilidade, toda folhagem que existe, diante da nossa vista, tem utilidade. É preciso estudo para saber que fim ela tem, porque todas têm um fim. Eu por exemplo não sei, se eu tivesse na minha infância começado nisso, às vezes não sabia todas, mas sabia muito mais que sei hoje.
\end{abstract}

Senhor José, no período em que foi gravado o documentário, fazia garrafadas para fornecer cura a seus clientes. Segundo ele, a reza que faz efeito é a reza da natureza, é da terra, é do mato. Revela as particularidades dos métodos de tratamento da medicina natural em contraste com a medicina ocidental. Segundo ele, considerar a lua como um fator, em que fase ela está, garante que certos males sejam evitados. Em muitos casos, deve-se respeitar a lua minguante para fazer algum tratamento. Segundo o senhor José,

Tem mais de mil. Tem remédio interno e tem o remédio externo. $\mathrm{O}$ remédio externo, o senhor não pode beber, se beber, morre. É veneno. Tem que ter ciência disso, pro freguês que depender desse remédio, explicar a eles que é só externo. Se beber, morre. Agora, se eu não tiver conhecimento disso, posso matar um ou outro. O médico tem seu diploma, não tem? Ele tá salvo de qualquer coisa, morreu ou viveu, pra ele é a mesma coisa, não fere em nada. Agora, eu não, fere. A mim, fere. Agora 
eu não tenho, não tenho diploma de curador, de raizeiro. Se tivesse diploma eu também tava livre de passar perseguição. Mas eu não tenho, então eu tenho que trabalhar com muita firmeza, né? Eu tenho que tratar meus clientes com muita firmeza. Aquilo que pode beber, pode beber. O que não pode, não pode. Se beber é por conta deles, mas não que eu mandasse beber.

Esta fala nos evidencia o conjunto de vetos impostos a esta forma específica de conhecimento. Além disto, muitos desses sábios sofreram por não terem suas atividades reconhecidas. A falta de validade atribuída a sabedorias como a de seu José é um dos fatores que resulta do binômio modernidade/colonialidade, que asseguraram validade apenas ao conhecimento científico. Muitos desses saberes não hegemônicos acabam tendo contornos como esotéricos, menores, restritos e supersticiosos na ética com seus ritos de cura.

Na publicação Benzeduras e Rezas, o pesquisador Muniz de Jagun, líder espiritualista da Casa das Palhas Kwè de Obaluaiyè, afirma logo em sua introdução que "A Benzedura não é um trabalho espírita, e nem tampouco católico, a Benzedura é uma ciência à parte, advinda do conhecimento dos grandes Pajés" (Jagun, 2019, p. 8). Neste caso, o estudo promove a possibilidade de se expandir a reflexão a respeito das raízes das sabedorias do benzimento.

No roteiro das práticas religiosas do território sul-fluminense do Vale do Paraíba, refletir sobre as performances incorporadas das benzedeiras na região revela a possibilidade de afirmação da ancestralidade e sabedoria de muitas tradições. Diferente de um olhar voltado para a extração e o consumo da natureza somente pela via da exploração, como tem sido a tendência principal nas sociedades capitalistas, outras tradições são capazes de elaborar o desenvolvimento de forma a integrar um pensamento mais sustentável e sintonizado com seus valores e costumes. O historiador e ativista guianense, Walter Rodney, descreve como a relação extrativista tal como a cultivada desde a época moderna pode se contrapor a de outras sociedades:

Uma das realidades mais difíceis de explicar é o desenvolvimento desigual das forças produtivas. Parte da resposta deve ser procurada no diferente condicionalismo natural que envolve a formação social considerada e outra parte na superestrutura dessa mesma sociedade. Isso significa que a luta pelos meios de subsistência cria formas de relações sociais, sistemas políticos, padrões de comportamento e crenças que em conjunto formam a superestrutura - que não é nunca exatamente a mesma em duas sociedades. Os elementos superestruturais integram-se entre si e com os da base material. Por exemplo, os padrões políticos e religiosos interligam-se e são 
muitas vezes indestrinçáveis. A crença de que determinada floresta é sagrada, interfere com a base econômica, visto que essa floresta não pode ser abatida e o terreno aproveitado para o cultivo. Não obstante, em última análise, a passagem para uma fase mais avançada do desenvolvimento humano depender sobretudo da capacidade técnica do homem para dominar o ambiente, é preciso ter sempre presente que as peculiaridades superestruturais de qualquer sociedade tem uma considerável importância no processo de desenvolvimento (Rodney, 1975, p. 20).

A partir destes argumentos, concluímos que os valores e processos de desenvolvimento de uma sociedade em suas transições se distinguem a partir da forma como se relacionam com o ambiente. Entre uma ânsia que busca dominá-lo para extrair recursos em nome do desenvolvimento e a ideia de sociedades que partem de outras formas de organização, que têm como base dinâmicas mais sustentáveis, envolvem também as relações com a cultura, com a palavra, com a história, com o sagrado e com a sua conservação. Nestas, o desenvolvimento é entendido e organizado segundo valores que não se limitam à superexploração em prol do capital econômico. 


\section{4}

\section{A força da experiência}

Ao chegar neste ponto do trabalho, nos aproximamos das emanações de força que o benzimento pode conjugar, seja com uma lente ampla, visualizando as conjunturas do território religioso em que estão inseridas, seja com uma lente mais focada, compreendendo as diversas ativações de encantamento pelo conhecimento incorporado dos repertórios das benzedeiras do Vale do Paraíba do Sul-Fluminense. Guardiãs de conhecimentos ancestrais, as experiências do benzimento levam à cura e revelam outras formas de perceber e sentir o mundo no panorama contemporâneo. Para seguir na reflexão sobre o benzimento, iremos nos debruçar sobre o saber incorporado produzido na experiência da cura.

Como foi exposto ao longo desta dissertação, a compreensão dada ao saber científico na sociedade moderna pretende estabelecê-lo como verdade universal aquele que define, hierarquiza e que parece invalidar todos os outros. Reconhecendo que, novamente, não se trata aqui de polarizar e partir do pressuposto ocidental entre um ou outro, visamos anunciar outras possibilidades para se pensar sobretudo a noção de experiência e suas bases de conhecimento.

O filósofo espanhol Jorge Larrosa Bondía, em seu artigo Notas sobre a experiência e o saber de experiência, reconhece na força da ativação das palavras a produção de sentido ao criar realidades e, às vezes, conduzir potentes mecanismos de subjetivação (Bondía, 2002, p. 20). Assim, o também pedagogo traz a reflexão sobre o pensar, exercício de dar sentido ao que somos e ao que nos acontece. "E isto, o sentido ou o sem-sentido, é algo que tem a ver com as palavras" (ibid., p. 21).

A reflexão do autor passa pela definição de Aristóteles, que definiu o homem como zôon lógon echon, que tem a tradução mais difundida em "animal dotado de razão". Bondía sugere que a expressão estaria mais próxima de "vivente dotada de palavra", reconhecendo novamente a dignidade ao que a palavra carrega. Ele define: 
O homem é um vivente com palavra. E isto não significa que o homem tenha a palavra ou linguagem como uma coisa, ou uma faculdade, ou uma ferramenta, mas que o homem é palavra, que o homem é enquanto palavra, que todo humano tem a ver com a palavra, se dá em palavra, está tecido de palavras, que o modo de viver próprio desse vivente, que é o homem, se dá na palavra e como palavra (idem).

Bondía reconhece que as atividades que consideram as palavras - as mesmas que nomeiam o que fazemos e o que nos dá sentido -, recorrem a uma técnica aplicada e, por isso, também passam pelas "lutas pelas palavras, pelo significado e pelo controle das palavras, pela imposição de certas palavras e pelo silenciamento ou desativação de outras palavras são lutas em que se joga algo mais do que simplesmente palavras, algo mais que somente palavras" (idem). Partindo das forças que atravessam a escolha de uma palavra, é possível associá-la ao exercício do benzimento. Uma vez já definido que o fazer da performance incorporada localiza uma episteme, uma forma de conhecer, entendemos que nesta prática as palavras enunciadas e as pausas para os silêncios dizem muito mais do que sua forma, pois carregam forças, produzem e dão sentido ao exprimir o cuidado.

Como afirmado, a experiência do benzimento pode ser determinada como cada benzedor irá ativar seus procedimentos, quais fundamentos serão recorridos e como será feita a performance incorporada da cura. Desta forma, "a experiência é o que nos passa, o que nos acontece, o que nos toca. Não o que se passa, não o que acontece, ou o que toca" (idem). Há aí um compromisso com a singularidade, a particularidade e a construção do sentido no ato da experiência, e aqui associamos ao benzimento.

Bondía mobiliza Walter Benjamin para refletir e evidenciar o que seria a denunciada pobreza de experiências que caracteriza o nosso mundo. $\mathrm{O}$ autor elenca como o excesso de informação, o excesso de opinião, a percepção da falta de tempo e o excesso de trabalho são motivos pelos quais a experiência é cada vez mais rara. Ao trazer a ênfase contemporânea a esses compromissos, a primeira ideia de informação passa pelo saber, e aqui não no sentido de "sabedoria", mas no sentido de "estar informado" (ibid., p. 22). Assim, Bondía indica a necessidade de separar experiência de informação. No que é associado o processar de uma informação como deter um conhecimento, invalidamos a experiência do aprendizado (idem). Para tal paradigma, uma vez que o sujeito moderno é informado, ele é convocado a 
opinar. A obsessão pela opinião, para o pedagogo, faz com que nada nos aconteça (ibid., p. 23). Como afirma Bondía:

A opinião seria como a dimensão "significativa" da assim chamada "aprendizagem significativa". A informação seria o objetivo, a opinião seria o subjetivo, ela seria nossa reação subjetiva ao objetivo. Além disso, como reação subjetiva, é uma reação que se tornou para nós automática, quase reflexa: informados sobre qualquer coisa, nós opinamos. Esse "opinar" se reduz, na maioria das ocasiões, em estar a favor ou contra. Com isso, nos convertemos em sujeitos competentes para responder como Deus manda as perguntas dos professores que, cada vez mais, se assemelham a comprovações de informações e a pesquisas de opinião. Diga-me o que você sabe, diga-me com que informação conta e exponha, em continuação, a sua opinião: esse dispositivo periodístico do saber e da aprendizagem, o dispositivo que torna impossível a experiência (idem).

Após ressaltar esses impeditivos para que a experiência ocorra na sociedade moderna, o autor traz como terceiro lugar a falta de tempo. Na sociedade do consumo, tudo passa depressa, somos disputados por estímulos instantâneos, pontuais e fragmentados:

A velocidade com que nos são dados os acontecimentos e a obsessão pela novidade, pelo novo, que caracteriza o mundo moderno, impedem a conexão significativa entre acontecimentos. Impedem também a memória, já que cada acontecimento é imediatamente substituído por outro que igualmente nos excita por um momento, mas sem deixar qualquer vestígio. [...] Por isso, a velocidade e o que ela provoca, a falta de silêncio e de memória, são também inimigas mortais da experiência (idem).

Por último e em quarto lugar, o autor traz o excesso de trabalho como impeditivo para a experiência. Muitas vezes, a ideia de experiência é lida como sinônimo de trabalho, aquilo que vem do fazer ou da prática. Desta forma, a ideia de experiência é capturada e convertida em mercadoria, em valor de troca. $\mathrm{O}$ autor, além de mostrar como são processos distintos, destaca como aquilo que atribuímos ao "trabalho" é também inimigo da experiência.

Ao tratar os impeditivos da experiência, Bondía traça o perfil do sujeito moderno, sempre animado por uma ansiedade por fazer algo, ainda que não saiba o quê. Este imperativo do fazer se torna uma ansiedade angustiante e seu chamado insaciável desemboca em outro paradoxo, o de, no fim das contas, o querer tudo fazer desemboque em um "nada nos acontece" (idem).

Buscando elaborar uma análise crítica deste sujeito moderno, Bondía formula então a ideia do sujeito da experiência, aquele que possui um compromisso com 
uma abertura essencial ao mundo, aos acontecimentos. O sujeito da experiência dá possibilidade ao saber da experiência, aquilo que se adquire "ao que lhe vai acontecendo ao longo da vida e no modo como vamos dando sentido ao acontecer do que nos acontece" (ibid., p. 27). Na produção do sentido e/ou do sem-sentido, este saber particular, ligado a um indivíduo ou a uma comunidade, produz uma ética (um modo de conduzir) e uma estética (um estilo). Entende-se a pluralidade como base da lógica da experiência. Assim, o caminho objetiva acessar o desconhecido, algo que não se pode prever, mas que na experiência se gera, se ativa.

A partir das palavras de Bondía, remeto aos encontros que fazem parte da minha formação enquanto sujeito, vivenciados nas experiências relatadas no capítulo anterior com Dona Fátima, Nara e tia Rose. O benzimento, independente da cura que se almeja, é um momento de conexão pelo cuidado e isto requer uma atenção e um modo de fazer que demanda o desenvolvimento de sensibilidades. A unanimidade relatada pelas benzedeiras é que de nada adianta buscar sanar as dores (físicas ou existenciais) se não tiver conexão e fé na condução da cura. O que se promove na experiência do benzimento passa pela confiança nessas guardiãs na revitalização do ser, pela construção e acesso a gestos que devem ser tonificados no cultivo do encontro, da sintonia com o tempo, da escuta ativa, do estar aberto ao outro e da promoção de uma conexão de um bem que atravessa os envolvidos na reza.

A cura é uma criação, um exercício, um preparo que se dá levando em conta tratamentos específicos, longe de soluções rápidas - como uma escolha em farmácias disponíveis vinte quatro horas por dia. O encontro é então o meio possível, o que se gera enquanto conexão com essa experiência.

A dissertação $A$ vida das benzedeiras: caminhos e movimentos (2019), da antropóloga Taísa Lewitzki, apresentada na Universidade Federal do Paraná, traz uma pesquisa etnográfica feita com as benzedeiras na região centro sul do Paraná. O trabalho de Lewitzki, que recebeu menção honrosa no prêmio ANPOCS (Associação Nacional de Pós-Graduação e Pesquisa em Ciências Sociais) 2020, traz reflexões sobre o benzimento, reunindo a militância e a importância dos encontros de mulheres que exercem as práticas tradicionais de cura, como benzedeiras, curandeiras, costureiras de rendiduras, remedieiras, parteiras e massagistas tradicionais. O Movimento Aprendizes da Sabedoria (MASA) é uma organização 
que marca as articulações pela manutenção de suas tradições e garantia de direitos das benzedeiras daquela região.

As reflexões de Lewitzki contribuem para este estudo e expandem noções, como o aspecto econômico, proporcionadas na experiência do benzimento:

A economia do benzimento, além de complexa, é potente, nela se encontram e se entrecruzam linhas de vida que exprimem relações de amizade, solidariedade, parentesco e compadrio. Uma forma de vida tecida por benzimentos, visitas, presentes, favores e afilhados que se coloca na contramão do mercado capitalista. Porque diferente dele, para as benzedeiras a saúde não é um produto rentável, mas uma relação de vida que permanece para além da prática do benzimento. $\mathrm{O}$ caminho das benzedeiras oposto ao caminho das relações comerciais, é possível pelo coletivo em detrimento ao individual. Mesmo que elas tenham trajetórias e especialidades que enaltecem sua individualidade, sua ação é coletiva e em prol do bem comum, pois nenhuma pessoa é excluída da rede da benzedeira; pelo contrário, em sua casa são acolhidas pessoas pertencentes a diferentes religiões, classes econômicas, lugares e idades. Sendo que seu papel de mediação anima o processo de troca-dádiva, e a transmissão, distribuição e repartição de conhecimentos, bens e serviços que acontece em sua casa (Lewitzki, 2019, p. 47).

Na contramão de capturas voltadas unicamente para a produção de capital, o acesso às benzedeiras, como ressalta Lewitzki, marca um outro modo de perceber o valor das coisas e a retribuição pela troca ao serviço disponibilizado por essas agentes da fé. O acolhimento gerado pelas guardiãs da cura, como exposto na pesquisa de Lewitzki, marca a importância do encontro para a realização da cura, por suas trocas de saberes e potencialidades geradas.

A visibilidade das benzedeiras da região centro sul paranaense, promovidas também por mapeamentos sociais, fortaleceu a luta do MASA, gerou aprovação de leis municipais de reconhecimento da identidade da comunidade destas agentes e a regulamentação do direito de livre acesso à coleta de plantas medicinais em certos municípios. O trabalho conjunto e o reconhecimento dessas muitas sabedorias tradicionais promovem uma ecologia de saberes em constante atividade.

Parte da investigação realizada para subsidiar este estudo usou como ferramenta analítica informações veiculadas em matérias jornalísticas. Acompanhamos assim, especialmente contrapondo com textos oficiais do passado, que privilegiavam Valença a mitologia em torno das fazendas de café, notícias sobre a emergência de transformações e atualizações sobre o benzimento. Aqui, 
tratamos desta prática não somente no território sul-fluminense, mas pela ótica da expansão do conhecimento das rezas pela cura.

"É bom esquecer, no entanto, aquele estereótipo das velhinhas em trajes puídos em casebres escuros com dizeres sussurrantes. Na era das redes sociais, as benzedeiras (a maioria é mulher) são jovens, antenadas e conectadas". A matéria "Benzedeiras surgem em versão redes sociais" ${ }^{37}$, do jornalista Edison Veiga para o Estadão em outubro de 2020, traz um novo panorama das atividades de dar a bênção em forma virtual. Apesar de o trecho destacado revelar estereótipos de benzedeiras tradicionais ligadas ao aspecto da escassez, parte da análise buscou entender as dimensões em que estas novas atividades têm se apresentado e atuado.

A matéria se inicia apresentando os números de seguidores de páginas de projetos nas redes sociais que reúnem "mutirões de benzedores" - "ambulatórios" para se depositar a intenção das bênçãos, tudo de forma voluntária e online. A matéria ainda se compromete a apresentar como muitos desses projetos têm a iniciativa em resgatar o que se chama cultura do benzimento.

"Meu objetivo é resgatar a arte ancestral do benzimento a curto prazo. A longo prazo, que a tradição familiar seja retomada", afirmou Pâmela Souza na reportagem, idealizadora do projeto Florescer Bento. A partir desta matéria tem-se a ideia de uma formação para o benzimento. Segundo o relato da benzedeira, tudo começou no resgate das raízes do benzimento em sua família, criando uma escola de formação, difundindo os princípios para a atividade. Destaca que a prática de benzer em si jamais deve ser cobrada. É relatado que o projeto já capacitou 1,6 mil pessoas e o depoimento de uma das benzedeiras formadas pelo Florescer Bento é que encontrou um lado seu "muito bonito, forte, que nem sabia que existia", passando a benzer os próprios filhos. O "despertar" para o benzimento é proposto por parte dessas benzedeiras que atuam nas redes sociais, e muitas delas já admitem ter alcançado muitas pessoas, em sua maioria mulheres.

A matéria também traz o movimento de reinvenção do benzimento pela bióloga e terapeuta Jacqueline Naylah, já citada neste estudo no capítulo anterior. Naylah é reconhecida como pioneira desse movimento, e a partir de sua pesquisa e

\footnotetext{
${ }^{37}$ Disponível em: $<$ https://brasil.estadao.com.br/noticias/geral,benzedeiras-surgem-em-versaoredes-sociais,70003478956>. Acesso em: 14 mar. 2021.
} 
repertório incorporado, passou a buscar formas de perpetuar o legado desses ritos de cura. A benzedeira publicou Diário de uma benzedeira e Eu te benzo: O legado de minhas ancestrais. Para ela, da mesma maneira como sua avó podia atender em casa, ela pode fazer o mesmo de forma remota pelas redes sociais.

Em seguida, a matéria segue com o depoimento de pesquisadores do campo religioso para contextualizar o benzimento nos campos político, religioso e cultural. Para o teólogo e historiador Sérgio Ribeiro Santos, o benzimento é resultado do processo de sincretismo e está radicado no catolicismo popular. Para ele, a "extinção" do benzimento está relacionada a processos como a urbanização, a racionalização da religiosidade e o acesso à medicina ocidental. Sobre os processos relacionados à Igreja Católica, o vaticanista Filipe Domingues relata que a Igreja não condena os benzimentos, ao contrário, até os incentiva, mas de fato a Igreja não reconhece a validade sacramental dessas bênçãos. Já o sociólogo e biólogo Francisco Borba Neto, do Núcleo Fé e Cultura da PUC de São Paulo, associa o benzimento a uma prática comum do catolicismo; o "problema", para ele, seria alguma "pretensão de uma ação 'mágica' da bênção", destacando a diferença entre ritos afros e indígenas, localizando o benzimento dentro da religião católica sob argumentos de que não são admitidos "entorpecimento dos sentidos por parte de quem abençoa - com bebidas alcoólicas ou alucinógenos". A matéria não traz informações sobre onde se localizam essas outras práticas e o que estaria fundamentado nesta "diferente" ideia de benzimento.

Ao finalizar, o jornalista recorre ao depoimento de Naylah, que afirma que seus gestos são ecumênicos, ao se identificar com todas as religiões e ao mesmo tempo nenhuma delas. Para ela, esta definição se faz presente na cultura do benzimento: os altares das benzedeiras dedicam sua devoção a muitas divindades, "Lá em cima todos se entendem".

Junto à leitura da matéria jornalística, partimos para a reflexão do que essas novas atividades indicam como resgate ao benzimento. Em Eu te benzo: O legado de minhas ancestrais, Naylah traz o resultado de suas reflexões, apresentando procedimentos e ritos da cultura do benzer. A benzedeira traça e reconhece o repertório de conhecimentos que muitos benzedores trouxeram para sua vida, como a força ancestral de sua avó Eni. 
Ao traçar um panorama do universo do benzimento, Naylah resgata valores como o reconhecimento de forças para a ativação da reza e a importância da intuição, a partir do desenvolvimento de sensibilidades que promovem a conexão com a cura.

Rezo tem que sair da alma para tocar a alma de quem será benzido. Rezo nunca é algo a ser decorado, rezo é para ser sentido. Não importa o que se diga, pois às vezes nada é dito (Naylah, 2019, p. 55).

Já no fim de seu livro, no que se refere ao compromisso de perpetuar o seu conhecimento, Naylah reconhece o âmbito conflituoso. Sabe que tem um peso ao aparecer nas redes sociais e nas mídias estampando o que seria o curso "que ensina a benzer", como se quisesse "ganhar dinheiro ensinando o 'padre a rezar missa' (ibid., p. 125). Ela ressalva

Chegamos em uma Era onde mesmo desconhecendo o histórico de vida e a conduta do outro, a primeira atitude sempre é "ver o circo pegar fogo". Estamos em bolhas digitais, em que os vínculos são voláteis e o tempo corre aceleradamente... uma palavra mal interpretada pode ser corrosiva (idem).

Assim, a benzedeira reconhece o seu cuidado naquilo que promove, e destaca os estereótipos que circulam o universo do benzimento:

\begin{abstract}
A verdade é que imaginamos toda benzedeira como uma senhorinha, de cabelos branquinhos, com a coluna curvada, um raminho de arruda nas mãos e a oração que foi recebida de suas ancestrais. Mas estou aqui para dizer que todos nós, benzedeiros e benzedeiras - começamos a benzer ainda jovens, nos vestimos do jeito que gostamos. Nosso conhecimento vem do nosso despertar de tudo que nossos ancestrais nos deixaram e também de todos os livros empilhados em nossas cabeceiras (ibid, p. 126).
\end{abstract}

O despertar para a prática do benzimento é um compromisso também de outra benzedeira destacada na matéria do jornal Estadão. Pâmela Souza, idealizadora do Florescer Bento ${ }^{38}$, promove com seu projeto cursos e oficinas para novos benzedeiros, presencialmente em São Paulo. O projeto nas redes sociais promove um acervo amplo de diferentes conteúdos sobre o benzimento, com vídeos de benzedores, matérias jornalísticas e pesquisas sobre o tema. Os canais do projeto também transmitem rezas, benzimentos e promovem ambulatórios virtuais de

\footnotetext{
${ }^{38}$ Disponível em: $<$ https://www.facebook.com/florescerbento $>$. Acesso em: 14 mar. 2021.
} 
intenção de orações de forma gratuita. São pedidas algumas informações para intenção da reza e não podem ser feitas para terceiros sem a plena autorização.

O projeto se propõe também a reunir e comercializar alguns livros sobre o benzimento, entre eles O Livro dos Benzimentos Brasileiros, de Max Sussol. A publicação teve sua primeira edição em 1995 e foi reeditada em 2020 com um agradecimento à professora e benzedeira idealizadora do projeto, por utilizar sua obra para realização da formação. O livro reúne uma série de rezas e benzimentos, relatos sobre a prática e uma catalogação de procedimentos registrados de benzedeiras de todo país. O projeto destaca pelas redes sociais que o livro é um compilado de anos de pesquisa do autor sobre o tema.

A introdução do livro de Sussol é marcada pela perspectiva do médico e folclorista Osvaldo Rodrigues Cabral. É importante destacar que o texto tem como perspectiva a medicina oficial em comparação com a medicina popular utilizada no benzimento. Uma leitura apurada e crítica sob as denúncias do autor é necessária, ao presumir uma possível confusão do benzimento com atividades de "feiticeiros e "macumbeiros" (Sussol, 2020, p. 9). É preciso estar atento às entrelinhas e possíveis inverdades, como o que foi exposto no capítulo 2 sobre os limites da intolerância que expõem o racismo religioso, como elabora o professor Sidnei Nogueira. O texto expõe a boa intenção e os benefícios do recurso terapêutico do benzimento, mas demanda ressalvas, por determinar o que não seria o benzimento, ao fazer uma separação do que seria "benzedores-feiticeiros", "práticas de Magianegra", ligados à "perniciosidade” (ibid., p.11).

Nas páginas seguintes, o Livro dos Benzimentos Brasileiros reúne textos diversos, de reflexões do autor sobre as pesquisas com benzedeiras feitas por Cabral, e textos de outros folcloristas, como Luiz Beltrão, autor de Folkcomunicação (ibid., p. 17), Alceu Maynard Araújo, autor de Folclore Nacional (ibid., p. 18), Filomena da Silva Martins, autora de Escola de Folclore Brasil (ibid., p.20). O livro conta ainda com a reunião de entrevistas e fotos de benzedeiras feitas por Sussol e reportagens coletadas pelo autor. Numa delas, destaco:

Outros pontos oriundos da pesquisa, discutidos entre nós e contrastados com os entrevistados: curador umbandista e benzedeira católica são na mente popular, a mesma coisa. [...] 
A confusão, por outro lado, começa pelo próprio nome: benzedeira provoca uma associação de ideias com benção admitida e aprovada pela Igreja-católica. Pedem a intercessão dos santos. São católicos. Admitem que os feiticeiros espíritas têm poderes para o Mal. Fazem ritos mágicos imitando grosseiramente os sacramentos. Tudo contribui para aumentar o sincretismo religioso. Esse sincretismo e as ideias supersticiosas que o acompanham são muito prejudiciais para uma mente objetiva, consciente e sadia (ibid., p. 28).

A respeito desta passagem, vale sublinhar como o sincretismo é encarado de forma a destituir a fé cristã e diminuir certos valores culturais em práticas de cura. A reportagem sinalizada de Jenny Zilda A. Alves, Maria Marta M. Ferraz e Denise dos Santos Rosa enquadra as atividades do benzimento sob um viés classificatório e hierarquizante. A leitura condicionada e interessada dessas atuações as encara como superstições que vão contra a ideia racional projetada ao sujeito moderno, aos "homens de bem". A linha abissal que divide as atividades das "benzedeiras católicas" dos "feiticeiros espíritas" é marcada de racismo religioso.

Antes de entrar na coletânea de benzimentos, o livro traz uma entrevista com Ramatis, nome dado ao guia espiritual de Hercílio Maes que o orientou na escrita de seus livros. O texto A terapêutica exótica dos benzimentos traz a explicação do benzimento sob os parâmetros do espiritismo (ibid., p. 29).

A partir dos textos que Sussol reuniu em seu livro, é possível expandir a compreensão das ideias publicadas ao longo do século XX sobre o benzimento, situando-o sob uma ótica folclórica, uma demanda do projeto nacional moderno em que embarcam ideias que cercam os mitos do sincretismo. Ainda por seu conteúdo, o livro de 416 páginas, sendo 374 de procedimentos de benzimento, é um acervo feito também de registros de conversas com guardiãs da cura de todo país.

Além dos encontros e formações para benzedores presencialmente, numa rápida pesquisa virtual é possível encontrar diversos cursos que promovem a cultura do benzimento também no modelo Ensino a distância (EAD). O formato EAD tem tomado força nos novos modelos de aprendizagem, principalmente em contextos de isolamento social como os ocasionados pela pandemia da Covid-19 pelo mundo. Não só pelo tema, tratando-se de uma busca pela sensibilidade que almeja a cura, a necessidade de acionar meios de sustento por formações em formato digital é cada vez mais presente. 
A busca por profissionalização e por certificados digitais ampliou o acesso e a oportunidade, expandindo possibilidades de atuação a muitas pessoas. Mas é preciso também observar, pelas lentes daquilo que tratamos com Bondía, os procedimentos da ânsia do capitalismo em capturar tudo o que está disponível para ser engrenagem de lucro, gerando o esgotamento do tempo dado ao sujeito:

Esse sujeito da formação permanente e acelerada, da constante atualização, da reciclagem sem fim, é um sujeito que usa o tempo como um valor ou como uma mercadoria, um sujeito que não pode perder tempo, que tem sempre de aproveitar o tempo, que não pode protelar qualquer coisa, que tem de seguir o passo veloz do que se passa, que não pode ficar para trás, por isso mesmo, por essa obsessão por seguir o curso acelerado do tempo, este sujeito já não tem tempo (Bondía, 2002, p. 23).

A definição e denúncia de Bondía passa pela busca de preencher o tempo a todo custo. $\mathrm{O}$ que se entende como possibilidade de novos cenários de interação passa por estar-se atento a essas novas formações que têm em sua base reivindicar a cura e o cuidado. A prática de muitas dessas novas benzedeiras segue também pela troca de seus conhecimentos, gerando uma economia à parte daquela gerada pelo oferecimento de seus serviços voluntários, como relatado por Lewitzki na economia do benzimento.

No livro de Jacqueline Naylah, a benzedeira descreve no capítulo $A$ moeda da troca sobre o valor que deve ser dado ao servir espiritual. $\mathrm{O}$ benzimento, sendo reconhecido como um dom, tem seu uso comum a partir da caridade. A autora tenta desmistificar a ideia, afirmando que o desconforto gira em torno da palavra "cobrança" (Naylah, 2019, p. 70). Assim, a troca pela remuneração é incentivada por Naylah.

O universo pelo qual o benzimento transita é vasto e se apresenta como potente componente identitário. Retomando algumas reflexões dos estudos culturais de Diana Taylor, a autora marca como "A identidade cultural é altamente performativa" (Taylor, 2013, p. 179). Antes de trazer reflexões sobre possíveis funções normalizadoras e reguladoras dessa identidade, este estudo indaga sobre experiências que são geradas e sentidas nessas novas formas de reprodução do saber do benzimento.

Para ajudar a refletir sobre esta questão, o que a definição de Bondía sobre a experiência poderia trazer? 
A experiência, a possibilidade de que algo nos aconteça ou nos toque, requer um gesto de interrupção, um gesto que é quase impossível nos tempos que correm: requer parar para pensar, parar para olhar, parar para escutar, pensar mais devagar, olhar mais devagar, e escutar mais devagar; parar para sentir, sentir mais devagar, demorar-se nos detalhes, suspender a opinião, suspender o juízo, suspender a vontade, suspender o automatismo da ação, cultivar a atenção e a delicadeza, abrir os olhos e os ouvidos, falar sobre o que nos acontece, aprender a lentidão, escutar os outros, cultivar a arte do encontro, calar muito, ter paciência e dar-se tempo e espaço (Bondía, 2002, p. 24).

O encontro no benzimento se apresenta então como uma possibilidade de se promover a experiência com aquilo que Bondía propõe que deve ser restituído ao sujeito. As forças que sustentam o cuidado no benzimento é um convite à experiência. $\mathrm{O}$ que as benzedeiras, com atuação nas redes sociais, destacam é que o benzimento pode ser feito à distância. Na criação de um vínculo pela emanação de cura, "a energia transpõe os limites de espaço-tempo" (Naylah, 2019, p.113).

O que se coloca em evidência, desta maneira, é o compromisso da experiência pela manutenção da vida. Definido por Bondía, a experiência "funda também uma ordem epistemológica e uma ordem ética", com uma forma de saber "distinta do saber científico, do saber da informação, e de uma práxis distinta daquela da técnica e do trabalho" (Bondía, 2002, p.26).

Nas escolhas de palavras e ativações de força para além daquilo que significam habitualmente, Bondía promove uma reflexão das ideias de "conhecimento" e "vida", para que não haja uma apropriação utilitária dos termos ao se associar à noção do saber de experiência. Para o pedagogo espanhol, "A experiência e o saber que dela deriva são o que nos permite apropriar-nos de nossa própria vida" (ibid., p. 27).

A partir da reflexão trazida neste capítulo, compreendemos que o saber gerado na experiência deve convocar uma abertura para e pela pluralidade e diferença, pela singularidade promovida de cada ser. Nas atividades de promoção da cultura do benzimento, a noção de experiência deve ser assegurada, convocando a receptividade ao outro pela cura através de um diálogo ativo, que ilumina, guia e respeita as relações entre os seres. 


\section{5 Considerações finais}

Ao iniciar esta pesquisa sobre as práticas do benzimento, o objetivo era o de jogar luz sobre esta tradição através de diferentes lentes e perspectivas disciplinares para buscar traçar um quadro, ainda que provisório, sobre esta forma de manifestação de cura pela fé. Ao investigar os registros históricos da região a que este estudo se dedicou, compreendeu-se que as benzedeiras e suas atividades estão presentes em variadas tradições, como nas de matriz cristã, nas CTTros (Comunidades Tradicionais de Terreiros) e em outras expressões da fé. Deste modo, a reflexão se voltou para uma análise sobre fenômenos constitutivos do território religioso com a preocupação de se distanciar de uma tentativa de demarcar um ponto de origem, assim como a de defender uma essência ou elaborar uma cronologia cultural ou historiográfica.

Quando reconhecida como uma ramificação do catolicismo em sua vertente popular, a atividade das benzedeiras cai facilmente na classificação de uma prática religiosa menor. Isto ocorre quando o fenômeno do benzimento é entendido como um saber enraizado na religião católica, aí consistindo em sua essência. Sob esta ótica que, novamente, tentamos evitar, elementos externos aos dogmas católicos são encarados como uma contaminação. Parte dessa ideia vai em busca de uma obediência a uma ideia de origem, centrada na devoção cristã.

Ao contrário de apostar em uma visão essencialista, busquei olhar o benzimento a partir de processos constitutivos, o que pressupôs evitar a elaboração de uma hierarquia de valores quanto a seus elementos formadores. Como um contraponto, a presente análise partiu dos mecanismos de ativação da palavra como instrumento de revitalização do ser. Esta opção foi uma das estratégias de aproximação com as questões condutoras da pesquisa empreendida. A partir do repertório incorporado de cada benzedor, suas inserções e trajetórias individuais, este saber segue reverberando pela memória e pela oralidade de seus ativadores.

Como vimos no primeiro capítulo, o território valenciano guardou, em suas narrativas oficiais, um mito fundador. A era gloriosa do café é sedimentada nos valores coloniais, na exploração do trabalho, na ocupação de terras de comunidades 
tradicionais e produção em larga escala. Deste contexto, extraiu-se uma narrativa de cidade vocacionada para o progresso e para a modernidade, que, ao mesmo tempo, apagava a presença decisiva de formas de vida não sintonizadas, ou mesmo subalternizadas, por aquela narrativa identitária da glória valenciana. Naquele imaginário cultural, emerge um catolicismo conservador que, ao longo dos anos, desempenhou papel fundamental. Tais esforços de se celebrar e manter uma identidade nestes termos se encontram presentes seja no discurso canonizado da tradição, seja no cotidiano. Nossa experiência colonial é remota, embora ainda viva e sistematizada, também produz uma mentalidade incorporada, uma espécie de tradição que remanesce e estrutura laços sociais no contemporâneo. Ao propor novas prismas de leitura para as práticas do benzimento, foi necessário reivindicar experiências mais amplas que afirmam a presença de saberes tradicionais na constituição da sociedade local e, portanto, reelaborar a sua história, ainda que de forma modesta. A ideia de "glória" poderia assim ser expandida e abranger a diversidade de vivências e de tradições que resistem às tentativas sistemáticas de apagamento.

Dentro desta análise, o Quilombo São José da Serra foi trazido como exemplo de articulação coletiva que organiza e elabora estratégias de permanência e vínculo a valores afro referenciados. Central neste espaço comunitário, o jongo é uma das mais importantes referências culturais preservadas, funcionando como vetor de coesão sociocultural e como componente educacional para muitos habitantes. Neste Quilombo, a relação com o ambiente natural inclui a comunhão de forças e a articulação de práticas integradas de subsistência e de vivência do sagrado, incluindo o benzimento. Compreendemos, a partir dos pensamentos de Beatriz Nascimento e Abdias do Nascimento, que a organização quilombo é espaço de afirmação e conexão com África, com a manutenção de valores de descendentes vindos para cá, na articulação e trocas com outros grupos excluídos do projeto colonial, principalmente com os povos originários que já habitavam essas terras antes da colonização. $\mathrm{O}$ espaço quilombo foi entendido então como espaço de resistência anticolonial, permanência e abrigo de outros eixos civilizatórios que não os hegemônicos, e que se expande a muitas formas de organização, como as articulações das irmandades religiosas negras e as CTTros. 
Assim, ao abordar as Comunidades Tradicionais de Terreiros e seus aquilombamentos, visualizamos a partir das benzedeiras outros contornos, resistências e continuidades culturais pela fé. Como se tem afirmado ao longo deste estudo, essas guardiãs da cura têm em suas atuações o envolvimento e compromisso comunitário, estabelecendo uma rede de suporte e apoio permanente, transmitindo valores e ensinamentos para a manutenção da vida. Apesar de imposições e vetos epistêmicos, suas religiosidades e sabedorias resistem e permanecem gerando força vital.

O que se apresenta no relato de muitas benzedeiras é o compromisso com a fé que se ativa em favor do próximo, que toca o coração de cada um e reforça o compromisso ético com os fundamentos de suas tradições, evocando as suas ancestralidades e forças que se comungam no exercício da cura. Assim, por mais que seja efetiva a ativação do benzimento para qualquer ser, a fé trazida junto à experiência é o que garante que a revitalização seja realizada de maneira efetiva. Para essa prática religiosa, não se compreende a separação cabeça/racional do corpo/sentido. A fé se alastra pelo coração, é a força que mobiliza a ativação da cura na experiência do benzimento.

Pelo prisma dos valores afro-civilizatórios brasileiros, visualizamos muitas das contribuições, principalmente a partir dos princípios tradicionais da oralidade africana, o compromisso rigoroso com a palavra e a permanência de formas de inscrição que se dão pela memória. Como afirma o tradicionalista malinês Amadou Hampaté Bâ, "quando falamos de tradição em relação à história africana, referimonos à tradição oral" (Bâ, 2010, p. 167).

Ao refletir sobre os subsídios necessários para a manutenção e a preservação de sabedorias tradicionais, verificamos que o processo da modernidade de matriz colonial produziu um senso comum em torno de uma visão de mundo que parece validar apenas as formas escritas de sabedoria. A dignidade atribuída apenas às culturas dotadas de tradições textualizadas terminou por relegar culturas tradicionais a um plano supostamente inferior, associado ao atraso. Assim, segundo a análise do conceito de arquivo, para Foucault, é possível reconhecer o caráter de dispositivo atrelado a ele, sendo manuseado conforme o leitor o ativa. Ao fazer uso deste conceito, pudemos perceber as benzedeiras enquanto mantenedoras de sabedorias por suas oralidades, ainda assim no duplo sentido de arquivo exposto 
por Derrida: origem e comando. Por meio de suas oralituras, na incorporação de seus repertórios, as guardiãs das curas remetem a ensinamentos herdados, transmitidos oralmente, reafirmando humanidades e sabedorias tradicionais no momento da reza pela revitalização energética de quem precisar.

A observação, a partir das performances, passou então a localizar epistemes. A reflexão de Diana Taylor enfatizou o sentido pela transmissão de repertórios incorporados, em paralelo ou em tensão com os documentos oficiais de determinada cultura. Assim, se alcançou métodos de observação das oralidades por estas ferramentas que reconhecem e acessam outras construções e resgates narrativos.

Pela observação dos procedimentos de cura das benzedeiras, invadimos a tradição moderna com a performance de suas práticas religiosas, reconhecendo o cuidado de si e do outro, com base em sabedorias mantidas e repassadas pela tecnologia corporal herdada e incorporada sistematicamente, geração após geração. No compromisso e na reafirmação pelas forças ancestrais, os envolvidos na prática do benzimento acessam percepções de tempo e espaço que não estão condicionadas pela linearidade moderna e abrem-se para temporalidades heterogêneas, na sobreposição de tradições, valores, épocas.

A abordagem à resistência do povo Puri marcou o ressurgimento político de culturas de resistência, em contraponto ao brutal apagamento imposto pela lógica moderna colonial que deu forma à identidade oficial valenciana. Práticas do benzimento foram então localizadas como herança cultural de povos nativos, no reconhecimento de sabedorias ligadas às ervas, das forças e humanidades de toda a natureza. Foi levantada a hipótese de que o fato de essas práticas serem uma partilha com o sagrado que nos habita, revitaliza-se ao conectar muitas tradições. Reconhecer nessas cosmogonias os valores que nelas permeiam é a possibilidade de destacar virtudes que nos dignificam.

Ainda assim, enquanto fenômeno cultural, é preciso estar atento ao processo ocidental de promover esquecimento acompanhado de "novas descobertas", o que abre para as questões acerca da apropriação cultural e o esvaziamento de uma expressão cultural por um grupo hegemônico. Também pelas reflexões acerca das práticas do sensível, das experiências e do saber de experiência, identificamos certas armadilhas que comprometem a possibilidade de uma experiência em sentido 
amplo, momento em que nos aproximamos dos pensamentos de Jorge Larrosa Bondía. O excesso de informação, o excesso de opinião, a velocidade sempre acelerada em relação à percepção do tempo e o excesso de trabalho tem resultado em subjetividades modernas que se apresentam enquanto negação da experiência da vida.

No texto da dissertação reconhecemos como a cultura do benzimento vem se expandindo e alçando novos interlocutores pela ética do cuidado e pela criação de coletivos em nome da cura. Novas propostas e formas de atendimento vêm ganhando força, em vínculos e atuações virtuais com benzedeiras que assumem o compromisso da arte de benzer como prática de vida. A atividade dessas benzedeiras abre novas possibilidades de investigação acerca das experiências geradas por este fenômeno que se atualiza e convoca a tradição do benzimento.

Isto pôde ser observado em práticas e nos procedimentos rituais constituintes das ações das benzedeiras, em que o espaço de suas atuações se comunga com as forças de suas devoções, exercidas em suas casas e quintais. As experiências de vida trazem o conhecimento incorporado que garante a eficácia em solucionar problemas que se manifestam em doenças físicas e espirituais.

Como parte da análise, verificamos a presença do protagonismo da atuação de mulheres. $\mathrm{O}$ vínculo a tradições ancestrais as reconhece enquanto matriarcas, gestoras de sabedorias e autoridades nos campos em que estão inseridas. Assim, o ato do cuidado, historicamente vinculado e comumente atrelado às mulheres, deve ser destacado, o que explica o fato de serem cada vez mais raros homens que benzem.

Guardo em minha memória o cuidado de muitos benzedeiros, entre eles tios que rezavam e detinham as ativações das ervas para os cuidados de pessoas e animais. Tio Nardinho marca a lembrança mais antiga, de quando meus pais me levavam junto com meu irmão para sermos benzidos e curados por seus gestos. O tio benzedor morava na região rural de Valença, próximo de onde meu pai havia nascido e sido criado, em Santa Inácia, arredores de Pentagna. Muitas vezes tia Dulce participava do ato da reza, mas os procedimentos eram de conhecimento dele. Tio Nardinho aliviava as febres de meu irmão, abria seu apetite com apenas um raminho. A memória oralizada de meus pais é que os ramos secavam em sua mão, 
tamanha sua força. Era conhecido também que muitas pessoas levavam seus cavalos e gados picados por cobras para que meu tio pudesse curá-los. Dito e feito. Por vezes, ainda, o relato é que a cobra que havia picado a vítima aparecia logo após a reza.

Também guardo comigo a força do benzimento de Dona Esmeralda, mãe de tia Rose que participou das conversas para esta pesquisa. Minhas dores de cabeça eram sempre sanadas pelo seu benzimento. Se enquanto te rezava ela começasse a bocejar, era certo que iriamos precisar de mais tempo para ser benzido.

Além daqueles de que guardo a experiência por seus nomes, carrego também o benzimento de uma senhora que rezava com seu facão e espada de São Jorge. Depois dela, não lembro de ter tido mais pesadelos que tanto me acordavam no meio da noite. O benzimento era tão comum que, depois das brincadeiras de rua, era costume ver uma fila de crianças para serem revitalizadas e abençoadas.

Ainda sobre as memórias do benzimento na região, em 2009, colaboradores da sociedade civil com o apoio da Secretaria de Cultura e da Secretaria de Educação do Município de Valença realizaram uma homenagem à violonista e compositora Rosinha de Valença, que se estendeu às atividades das benzedeiras da região. Tendo como linha mestra a composição em parceria com Martinho da Vila "Benzedeiras Guardiãs", o projeto envolveu parteiras e benzedeiras, representantes de diversas religiões, médicos, assistentes sociais e muitos artistas da cidade.

A exposição gerou debates sobre o tema do benzimento, contando com seminários como "O Poder da Fé e da Oração", conduzida pelo Padre Medoro, e "As Mãos e as Folhas Que Rezam e Curam", conduzida por Lílian de Iansã. Durante o evento foram distribuídas mudas de plantas (principalmente ervas medicinais), apresentações de capoeira, samba de roda, folia de Reis e atendimento ao público pelas benzedeiras presentes. As atividades ocorreram no pavilhão da Catedral de Nossa Senhora da Glória, igreja matriz de Valença. ${ }^{39}$

São muitas as sabedorias populares e tradicionais de ativação pela cura na região a que este estudo se dedica. Na Feira Municipal da cidade de Valença, é

\footnotetext{
${ }^{39}$ Fonte: $<$ https://blogdovq.wordpress.com/2009/07/25/benzedeiras-guardias-homenagem-arosinha-de-valenca/>. Acesso em: 05 abr. 2021.
} 
comum ainda encontrar muitos raizeiros e sábios das ervas que comercializam e disseminam seus produtos e conhecimentos.

$\mathrm{O}$ ato de cuidar de si e cuidar de alguém deve ser visto com atenção para a construção de uma sociedade que zele pelo bem-estar de sua população. A Pesquisa para uma Política Nacional do Cuidado (2019) mostra que mais de 40\% dos brasileiros conhecem alguém que precisa de cuidados ${ }^{40}$ e que $95 \%$ acham importante a criação de uma lei que defina direitos e deveres para a profissão de cuidador. A pesquisa abrange principalmente as atividades dos cuidadores de pessoas que estejam incapazes, seja por limitação física ou intelectual, de fazer seus próprios cuidados, mas o que expande a noção de uma política que abranja e ampare a pergunta "quem cuida de quem nos cuida?".

$\mathrm{O}$ cuidado e seu fazer enquanto política presume o fundamento da solidariedade, o contato pela experiência com o próximo cada vez mais escasso pela globalização da indiferença, algo que vem sendo alertado por líderes religiosos como o Papa Francisco. A celebração do encontro, pelas lentes analisadas deste estudo, está ancorada em uma ideia de empatia, de compaixão pelo próximo, e menos de subserviência a uma caridade que envaidece e que, na verdade, impossibilita o contato real e a ajuda mútua. Das prateleiras de autoajuda e autoconhecimento que garantem resultados imediatos e pré-fabricados, o cuidado assume contornos individuais. Diante de fenômenos culturais cada vez mais comuns pela "cura em poucos passos", das soluções rápidas, o tratamento contempla um tempo, um percurso, uma apuração que denota um fazer, um preparo.

Como foi exposto, a cura, através das benzedeiras do Vale do Paraíba, se efetiva como exercício criativo e, por mais que cada uma traga o seu método, é também uma criação que garante o seu contínuo legado. É a partir das atividades de cura destas guardiãs que se quebram os quebrantos, as doenças e os males que acometem as humanidades, das dores físicas e das causadas pelo carrego colonial (Simas; Rufino, 2019).

\footnotetext{
40 Pesquisa publicada em dezembro de 2019 pelo Instituto de Pesquisa DataSenado. Acesso pelo link:

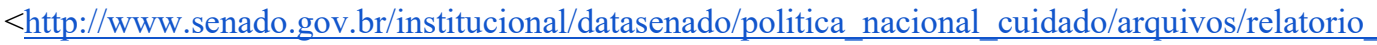
completo.pdf $>$. Acesso em: 23 mar. 2021.
} 
Pelo benzimento, entendemos como a vulnerabilidade é levada a sério, as fragilidades marcam áreas sensíveis pelo cuidado e que, dados os devidos tratamentos, oferecem apoios, conforto e fortalecimento pela revitalização do ser, numa ação incontornável de afirmação da vida. A prática da comunidade nasce na proteção dessas guardiãs, de uns aos outros, criando parentescos pela cura em comum. Laços de solidariedade.

Ao abordar a "cura" é possível caminhar em várias direções: no âmbito ancestral, enquanto exercício de conexão com a memória; no âmbito corporal, enquanto vitalidade do ser; pelo caráter político, enquanto liberdade e coletividade; na esfera íntima, como prática da alteridade e empatia; no sentido filosófico, como prática do devir; psicanalítico, como exercício da pulsão; jurídico, como gerar cidadania; pelo caráter artístico, no exercício da criação da experiência e no sentido performático, enquanto abertura e entrega ao mundo.

Com esta dissertação, espero ter a oportunidade de fazer uma revisão conceitual de minha própria história, de destacar contornos e ir atrás de heranças guardadas no seio familiar-comunitário. Pelas falas de tia Rose, visualizamos o "resgate cultural pra saber o que vai interferir na vida da outra pessoa". E enquanto resgate, ela determina não só enquanto exposição impessoal, mas "enquanto ser humano que pode ajudar o outro". 


\section{Referências bibliográficas}

ALAVINA, Fran. 110 anos de Umbanda, religião dos oprimidos. Outras Palavras. nov. 2017. [online] Disponível em:

$<$ https://outraspalavras.net/descolonizacoes/110-anos-de-umbanda-religiao-dosoprimidos/>. Acesso em: 03 abr. 2021.

ANDRADE, Antonio. et al. Indicionário do contemporâneo. PEDROSA, Celia. et al. (org.). Belo Horizonte: Editora UFMG, 2018.

AZEVEDO, Gilson Xavier de; LEMOS, Carolina Teles. As benzedeiras na tecitura da cultura, religião e medicina populares. Goiânia Agbook, 2018.

BHABHA, Homi K. O Local da Cultura. Belo Horizonte: Editora UFMG, 1998

BRAZ, Gislene; et al. A Introdução do café no Vale do Paraíba do Sul. Valença/RJ: Interagir Editora, 2020.

BONDÍA, Jorge Larrosa. Notas sobre a experiência e o saber de experiência. Rev. Bras. Educ. [online]. 2002, n.19, pp.20-28. ISSN 1413-2478. $<$ http://dx.doi.org/10.1590/S1413-24782002000100003>.

CARMO, Ione Maria do. "O caxambu tem dendê": Jongo e religiosidades na construção da identidade quilombola de São José da Serra. Dissertação (Mestrado em História) - Universidade Federal do Estado do Rio de Janeiro, Rio de Janeiro/RJ, 2012.

CASTRO, Felipe; et al. Quelé, a voz da cor: biografia de Clementina de Jesus. $2^{\mathrm{a}}$ ed. Rio de Janeiro: Civilização Brasileira, 2017.

DARDOT, Pierre; LAVAL, Christian. Propriedade, apropriação social e instituição do comum. Tempo soc. [online]. 2015, vol.27, n.1, pp.261-273. ISSN 1809-4554. https://doi.org/10.1590/0103-207020150114.

DERRIDA, Jacques. Mal de arquivo: uma impressão freudiana. Tradução: Claudia de Moraes Rego. Rio de Janeiro: Relume Dumará, 2001. 
INOCÊNCIO, Nelson Olokofá. Sujeito, corpo e memória. p.53-57. In: A Cor da Cultura - Saberes e Fazeres, v.1: modos de ver. Coordenação do projeto Ana Paula Brandão. Rio de Janeiro: Fundação Roberto Marinho, 2006

JAGUM, Muniz. Benzeduras e Rezas. 2a ed. 2019

LARAIA, Roque de Barros. Cultura: um conceito antropológico. 30 reimpressão: 2020. Rio de Janeiro: Zahar, 1986.

LEMOS, Marcelo Sant'Ana. O índio virou pó de café? - Resistência indígena frente à expansão cafeeira no Vale do Paraíba. Jundiaí: Paco Editorial, 2016.

LEWITZKI, T. A vida das benzedeiras: caminhos e movimentos. Dissertação de Pós-Graduação em Antropologia, Setor de Humanas da UFPR. Paraná. 242 p. 2020

LUCINDA, Maria da Consolação. Territórios Religiosos: conexões entre passado e presente. Curitiba: Appris, 2016.

MALOMALO, Bas'Ilele. Filosofia Africana do Ntu e a Defesa de Direitos Biocósmicos. In: Problemata. v.10 n.2 (2019). [online] DOI: $<\underline{\text { https://doi.org/10.7443/problemata.v10i2.49144> }}$.

MARTINS, Leda Maria. A oralitura da memória. In: FONSECA, Maria Nazareth Soares (org.). Brasil afro-brasileiro. $3^{a}$ ed. Belo Horizonte: Autêntica Editora, 2015.

MBEMBE, Achille. Necropolítica. $3^{\text {a }}$ ed. São Paulo: n-1 edições, 2018. ; Políticas da inimizade. $1^{\mathrm{a}}$ ed. Lisboa: Antígona, 2017

MENDES, Dulce Santoro; CAVAS, Claudio São Thiago. Benzedeiras e benzedeiros quilombolas - construindo identidades culturais. In: Interações. v. 19, n.1, jan./mar. 2018. [online] Acesso em:

$<$ https://doi.org/10.20435/inter.v19i1.1568 $>$.

MONTAURY, Alexandre. Rastros do comum e o imaginário das ausências. In: Contextos: Estudios De Humanidades Y Ciencias Sociales, (43). 2019. [online] Acesso em: http://revistas.umce.cl/index.php/contextos/article/view/1495.

NASCIMENTO, Abdias do. O Quilombismo. Petrópolis: Editora Vozes, 1980. 
NASCIMENTO, Maria Beatriz. Nossa democracia racial. 1977, p. 106-109. In: RATTS, Alex. Eu sou Atlântica: sobre a Trajetória de Vida de Beatriz Nascimento. São Paulo: Imprensa Oficial/Kuanza, 2006.

; Kilombo e memória comunitária: um estudo de caso. 1982, p. 109-116. In:

RATTS, Alex. Eu sou Atlântica: sobre a Trajetória de Vida de Beatriz Nascimento. São Paulo: Imprensa Oficial/Kuanza, 2006.

; O conceito de quilombo e a resistência cultural negra. 1985, p. 117-125. In: RATTS, Alex. Eu sou Atlântica: sobre a Trajetória de Vida de Beatriz Nascimento. São Paulo: Imprensa Oficial/Kuanza, 2006.

NAYLAH, Jacqueline. Eu te benzo: o legado de minhas ancestrais. $2^{\mathrm{a}}$ ed. Porto Alegre: Besourobox, 2019.

NOGUEIRA, Sidnei. Intolerância religiosa. São Paulo: Sueli Carneiro; Editora Jandaíra, 2020.

PINHEIRO, Théo Lobarinhas. Valença: dos Caminhos de Comércio à Indústria. Cadernos do Desenvolvimento Fluminense, Rio de Janeiro, n. 6, p. 5-18, 2015. [online] Disponível em:

$<\underline{\text { https://www.e- }}$

publicacoes.uerj.br/index.php/cdf/article/viewFile/17738/13109>. Acesso em 28 mar. 2021.

PURI, Dauá. Alkeh Poteh: Poeira de Luz. Uma publicação bilíngüe Puri (macrojê) - Português. Rio de Janeiro: Pachamama Editora, 2016.

RAMOS, Melissa Ferreira. Re-existência e ressurgência indígena: diáspora e transformações do povo Puri. (Dissertação do Programa de Pós-Graduação em Educação) Universidade Federal de Viçosa. Viçosa / Minas Gerais. 2017.

REIS, Paulo Pereira dos. O indígena do vale do Paraíba: apontamentos históricos para o estudo dos indígenas do vale do Paraíba paulista e regiões circunvizinhas. São Paulo: Governo do Estado, 1979.

REIS, Solange de Souza. Onde estavam os indígenas Puri quando o sistema os dava como extintos? Nós estamos aqui, vivos! Orando, rezando, curando, plantando, lutando, resistindo e ressurgindo. (Trabalho de Conclusão de Curso 
em Educação do Campo - Ciências da Natureza). Universidade Federal de Viçosa, Viçosa / Minas Gerais. 2020.

; Diários da Pandemia \#8: Opetahra e a ressurgência do Povo Puri. Teia dos

Povos. Jul. 2020. [online] Disponível em: $<$ https://teiadospovos.org/diarios-dapandemia-opetahra-e-a-ressurgencia-do-povo-puri/>. Acesso em: 03 abr. 2021.

VEIGA, Edison Edison Veiga. Benzedeiras surgem em versão redes sociais.

Estadão. Out. 2020. [online]. Disponível em:

$<\underline{\text { https://brasil.estadao.com.br/noticias/geral,benzedeiras-surgem-em-versao-redes- }}$ sociais, 70003478956>. Acesso em: 14 mar. 2021.

ROCHA, Joyce Alves. Quilombo São José da Serra: o etnoconhecimento na perspectiva socioambiental. 353f: il. Tese (Doutorado em Meio Ambiente). Universidade do Estado do Rio de Janeiro, Rio de Janeiro/RJ, 2014.

RODNEY, Walter. Como a Europa subdesenvolveu a África. Tradução de Edgar Valles. Lisboa: Seara Nova. 1975.

SANTOS, Boaventura de Sousa. Para além do Pensamento Abissal: das linhas globais a uma ecologia de saberes. In: Epistemologias do Sul. Org. SANTOS, Boaventura de Sousa; MENESES, Maria Paula. Coimbra: Edições Almedina, 2009.

SILVA, Camila Carvalho Gomes da. A identidade valenciana no Jornal Local. Dissertação (Mestrado em Comunicação) - Universidade Federal de Juiz de Fora, Juiz de Fora/MG, 2014.

SILVA, Gustavo Augusto Fonseca. Quilombo São José da Serra. Belo Horizonte: FAFICH, 2016. 16 p.

SIMAS, Luiz Antonio. Pedrinhas miudinhas: ensaios sobre ruas, aldeias e terreiros. Rio de Janeiro: Mórula Editorial, 2013.

; RUFINO, Luiz. Fogo no mato: a ciência encantada das macumbas. Rio de Janeiro: Mórula Editorial, 2018.

Almanaque brasilidades: um inventário do Brasil popular. Rio de Janeiro: Bazar do Tempo, 2018. 
. O corpo encantado das ruas. $6^{\mathrm{a}}$ ed. Rio de Janeiro: Civilização Brasileira, 2020.

SOUSA, Emanuella Geovana; BOAKARI, Francis Musa. Resistindo ao epistemicídio: em busca de uma literatura infantil afro-brasileira, moçambicana e angolana. In: Mulemba. Rio de Janeiro: Universidade Federal do Rio de Janeiro. v.10, n.19. jul.- dez. 2018. [online]. Acesso em:

$<$ https://doi.org/10.35520/mulemba.2018.v10n19a20559>.

SUSSOL, Max. O livro dos benzimentos brasileiros. São Paulo: Editora Posteridade. São Paulo: Difusão Cultural do livro, 2020.

TAYLOR, Diana. $\mathrm{O}$ arquivo e o repertório: performance e memória cultural nas Américas. Trad. de Eliana Lourenço de Lima Reis. Belo Horizonte: Editora UFMG, 2013.

TRINDADE, Azoilda Loretto da. A Cor da Cultura - Saberes e Fazeres, v.1: modos de ver / Coordenação do projeto Ana Paula Brandão. Rio de Janeiro: Fundação Roberto Marinho, 2006.

ZUMTHOR, Paul. Introdução à poesia oral. Tradução de Jerusa Pires Ferreira et al. São Paulo: Hucitec, 1997.

\section{Referência audiovisual}

ALQUIMISTA do Mato. Dir: Tom Job Azulay. Brasil: Vassouras/RJ. 1980. 16mm/Digital. (25 min.)

AS NAÇÕES do Rio de Janeiro. Co-produção: Núcleo de Cinema Vídeo da UNESA; Maria Fernanda Mocelin. 2003. Disponível em: < https://www.youtube.com/watch?v=TEVdHjn9uZo $>$. Acesso em 02 mar. 2021

DONA ANGELINA - REZADEIRA - VASSOURAS RJ. Dir. e prod.: Chico Abelha. 2014. Disponível em:

$<$ https://www.youtube.com/watch?v=IM7O9cMptoc $>$. Acesso em 04 abr. 2021.

DONA CÉLIA - BENZEDEIRA. Dir. e prod.: Chico Abelha. 2014. Disponível em: $<\underline{\text { https://www.youtube.com/watch?v=CCROND2QYaU> }}$. Acesso em 04 abr. 2021. 
KARAÍ Mirim e a cosmologia do ser, Vozes da ressurgência Puri - Episodio III Cosmologia e o Ser. Acesso pelo Portal do Povo Puri. 2019. Disponível em: $<$ https://1drv.ms/v/s!AoZMkO1ExG2nc3h7rt5 DObD1sw $>$. Acesso em 09 mar. 2021.

MOJUBÁ I | Ep. 01: Origens. Prod: Canal Futura. A Cor da Cultura. Disponível em: < 2021.

PUKY Na Thamati (Puri bem vivo). Dir: Zélia Balbina Ponã Puri. Acesso pelo Portal do Povo Puri. 2017. Disponível em:

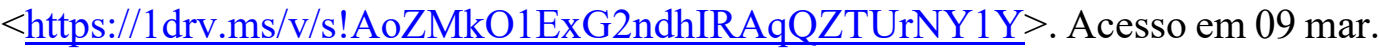
2021.

QUILOMBO São José da Serra. Prod: Luiz Fernando Sarmento. Disponível em: $<$ https://www.youtube.com/watch?v=f0as11-SpP4 $>$. Acesso em 04 abr. 2021.

RETRATO da Mestra Makota Valdina. Prod: Formação Transversal em Saberes Tradicionais UFMG. 2018. Disponível em:

$<$ https://www.youtube.com/watch?v=FAc4CJr4qtM $>$. Acesso em 04 abr. 2021.

\section{Páginas na internet}

A Cor da Cultura. Disponível em: $<\underline{\mathrm{http}}$ ://www.acordacultura.org.br $/>$ Acesso em: 04 abr. 2021

Centro de Memória do Povo Puri. Disponível em:

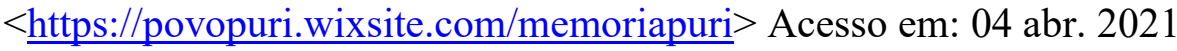

Pesquisa para uma Política Nacional do Cuidado (2019). Pesquisa publicada em dezembro de 2019 pelo Instituto de Pesquisa DataSenado. Disponível em: $<\underline{\text { https://www.senado.gov.br/institucional/datasenado/politica nacional cuidado/a }}$ rquivos/relatorio_completo.pdf>. Acesso em: 23 mar. 2021 